المكتبات الجامعية المصرية الحكومية الحديثة: جامعة الفيوم: دراسة حالة

$$
\text { مدرس بكلية الآداب - جبد الهادى سويفى الفداد }
$$

\title{
تمهيد:
}

الجامعة مؤسسة تعليمية تربوية، وهى تحقق احد اهدافها بتخريج اجيال واعية

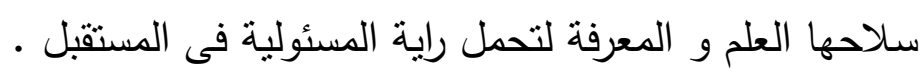

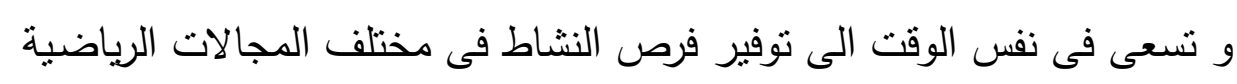

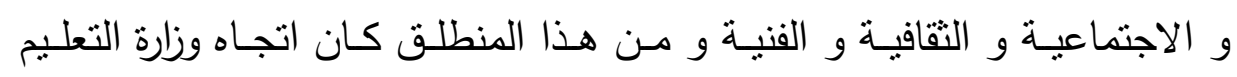

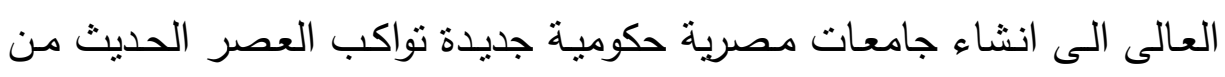

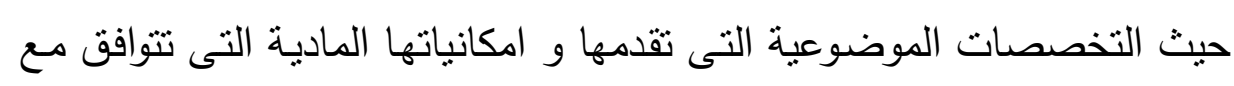
تكنولوجيا المعلومات المعاصرة.

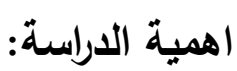
فى اطلى زيادة الطاقة الاستيعابية لمؤسسات التعليم العـالى فى مصر كاحد

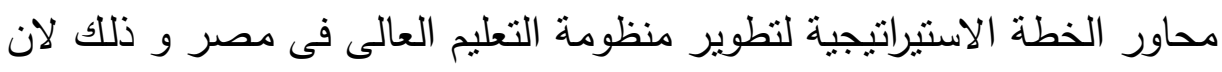

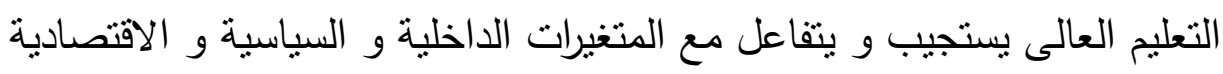
و الاجتماعية و التكييف مع المتغيرات الاقليمية و الدولية

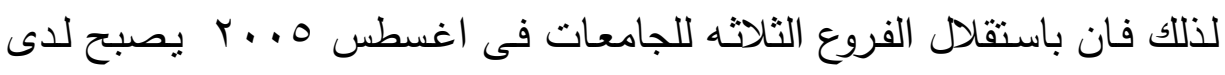

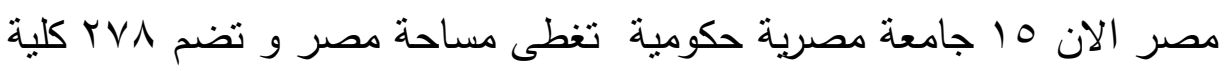

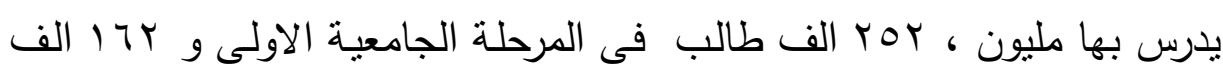

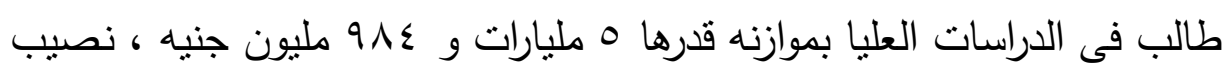

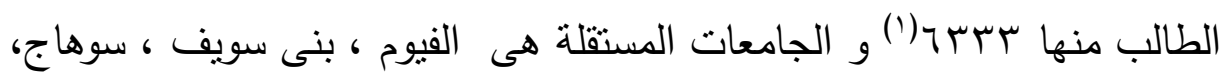

كفر الثيخ، بنها 
لذلك تكمن اهمية هذه الدراسة فى التعرف على الجامعات الحكومية المصرية

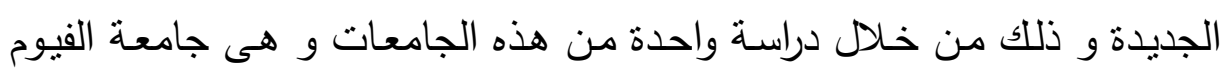

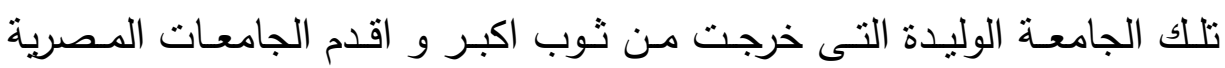
الحكومية و هى جامعة القاهرة. و ذلك بالتعرف على هذه الجامعة و نشائتها و امكاناتها الحالية و المستقبلية و هوده مدى مواكبتها للاتجاهات الحديثة فى الجامعات المصرية القديمة و الاقليمية بل نل

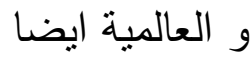

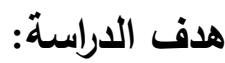

تهدف هذه الدراسة على التعرف الجامعات المصرية الحكومية الجديدة من خلال

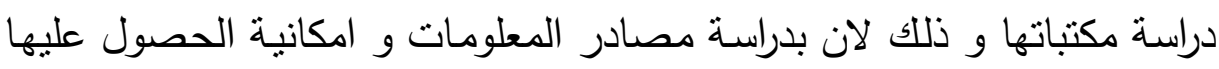

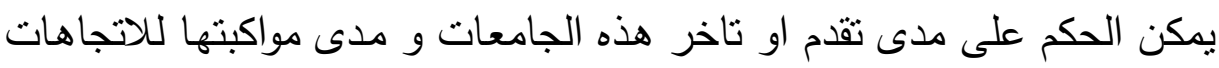
الحديثة فى الجامعات الاخرى و ذلك من خلال دراسة جامعة الفيوم و هى احدى الفى الفي الجامعات المصرية الحكومية الحديثة النشاة

منهج الاراسة

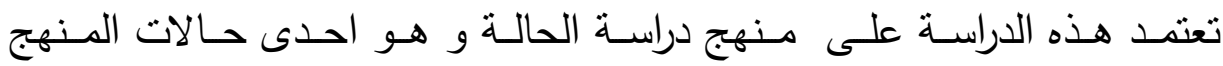
الميدانى الذى يعتمد على وصف الظاهرة و دراستها و تحليلها و ذللك باستخدام

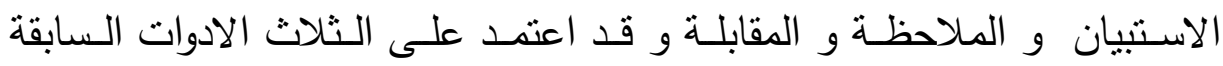

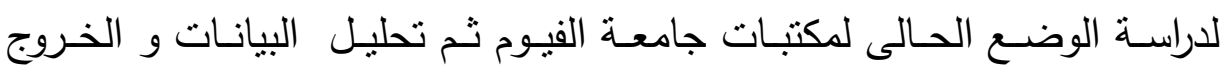
بمجموعة من النتائج

\section{جامعة القيوم}

(النشاه

بدا انثاء كليات جامعة القاهرة فى الفيوم عام 9 19 بانشاء كلية التربية و التى

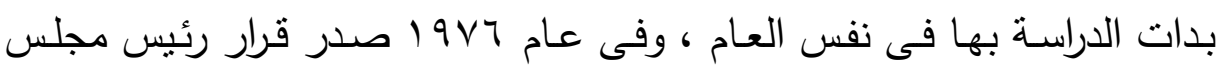
الوزراء رقم rع 11 بانثاء كليتى الزراعة و الهندسة ، و قد بدات 
الدراســة بكليـة الزراعـة عـام 9 ا و و الهندسـة اعتبـارا مـن العـام الجـامعى $.19 \wedge r / \Lambda r$

و فى عام 1911 صدر القرار الجمهورى رقم YNV بانشاء فرع لجامعة القاهرة باسم فرع الفيوم و بنى سويف ، و مقره محافظة الفيوم •

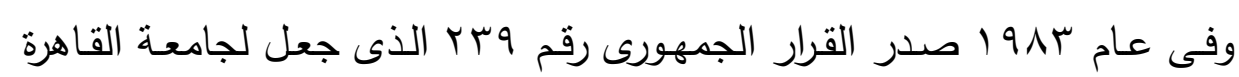

فرعين مستقلين لكل من محافظة الفيوم و محافظة بنى سويف (1) و كانت تضم جامعة القاهرة - فرع الفيوم عشر كليات بالاضافة بالاضـافة الى لى المعهد الفنى للتمريض و هذه الكليات هى:

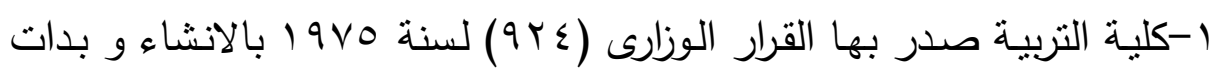
الدراسة بها العام الجامعى 19 197-V

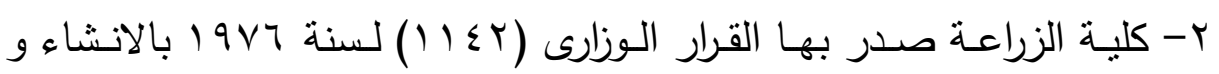
بدات الدراسة بها فى العام الجامعى 9 VV/VT

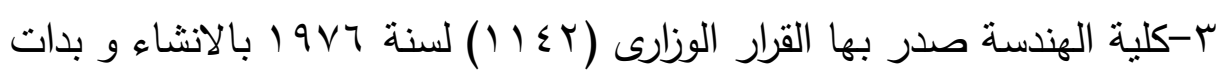

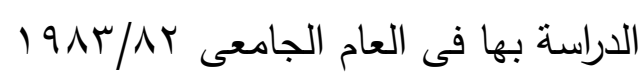

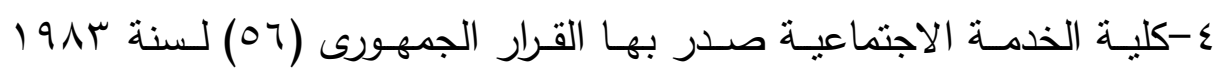

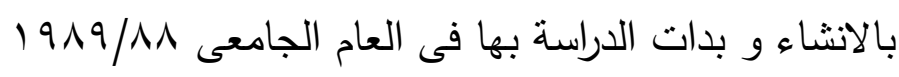

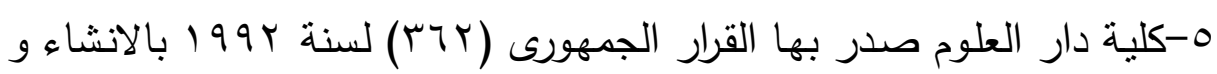

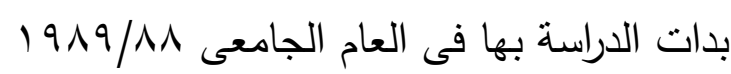
ج-كليـة العلوم صدر بها القرار الوزارى (rr) لسنة 990 19 بالانشاء و بـدات الدراسة بها فى العام الجامعى $1997 / 90$

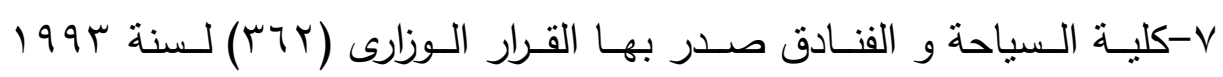
بالانشاء و بدات الدراسة بها فى العام الجامعى ع 190/9 


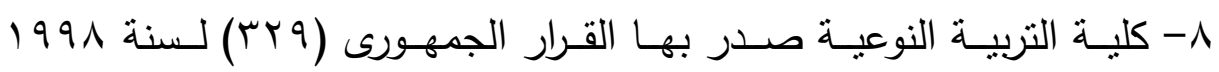

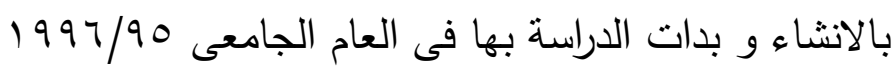

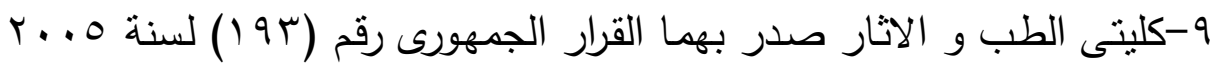

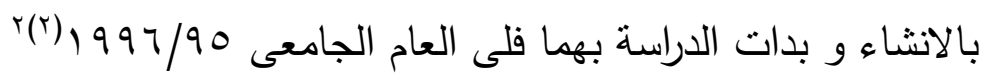

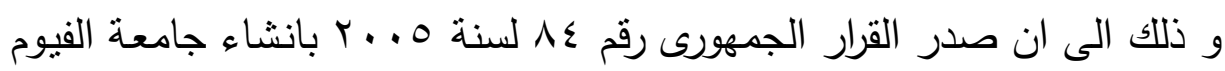

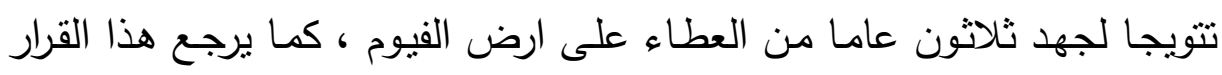

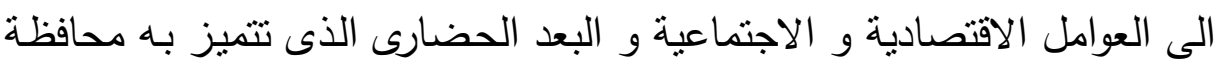

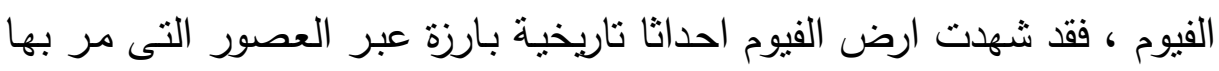

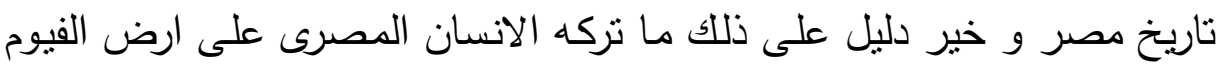
من شواهد و ابداعات.

و تضم جامعة الفيوم الان ثلاثة عشر كلية هى: التربية ، الزراعة ، الهندسة،

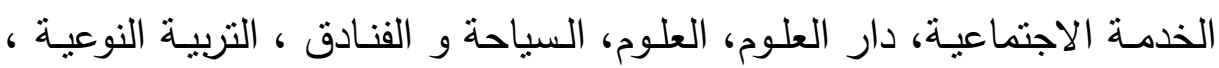
الاثار ، الطب ، بالاضافة الى المعهذ الفنى للتمريض .

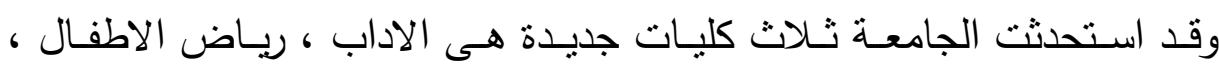

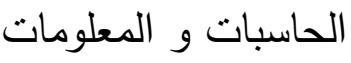

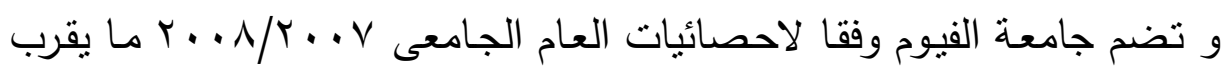

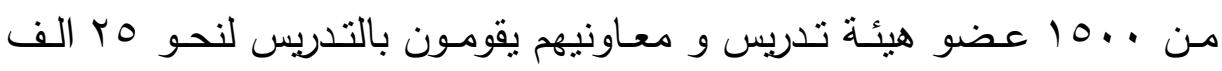

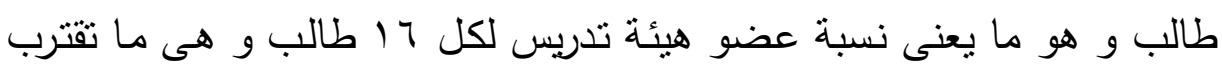
من النسبة العالمية. و لقد ولدت جامعة الفيوم فتية و لديها من المقومات و الامكانات ما يؤهلها لان

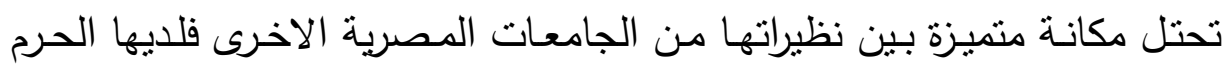

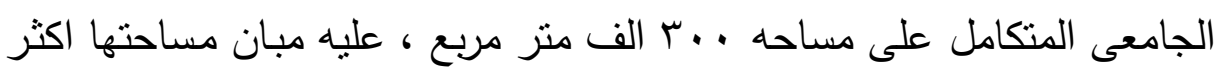

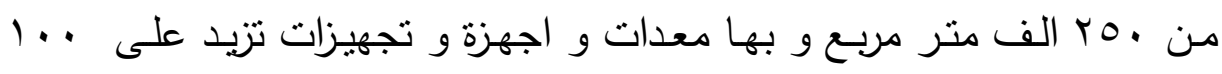




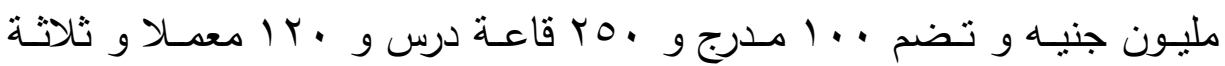
عنر مكتبة.

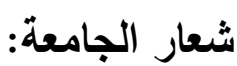
يتكون شعار الجامعة من نهر النيل العظيم بدلتاه مكونه حرف بداية كلمة الفيوم

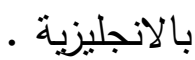

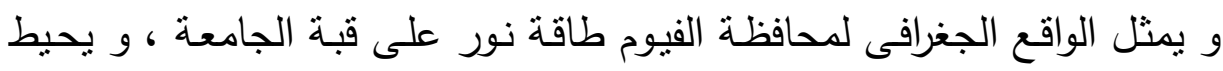
بها الساقية الشهيرة ، اما اللون الاخضر الذى تتمتع بها واحة الفيوم ، و يميز

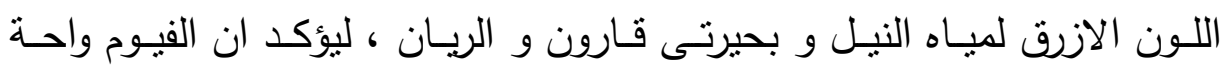

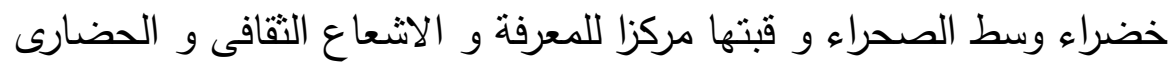

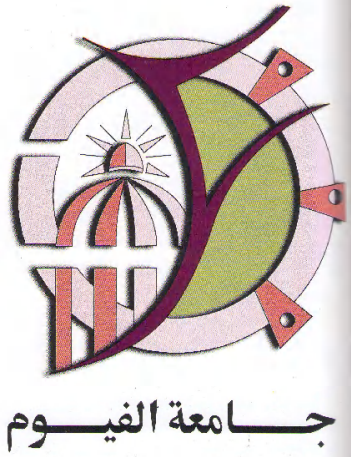

Fayoum University

\section{مكتبات جامعة الفيوم}

سبق الاثـارة ان جامعـة الفيوم تضم ثلاثنة عثر مكتبة اى ان لكل كلية مكتبة

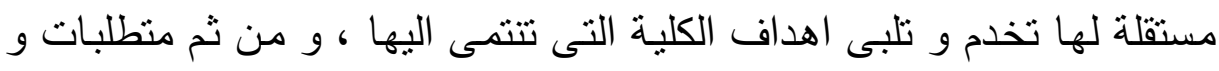
احتياجات الطلاب و الباحثين و اعضاء هيئة التنريس و العاملين فى كل كلية .

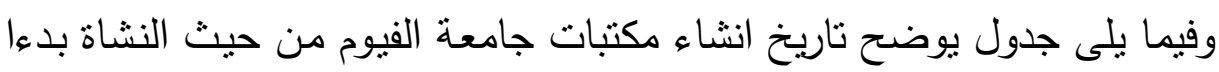

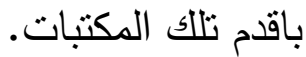

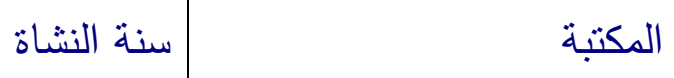




\begin{tabular}{|c|c|}
\hline 191. & التربية \\
\hline 1911 & الهندسة \\
\hline $191 \varepsilon$ & الخدمة الاجتماعية \\
\hline $191 \mathrm{~V}$ & الزراعة \\
\hline 1919 & دار العلوم \\
\hline 1991 & التربية النوعية \\
\hline 1998 & الاثار \\
\hline 1990 & 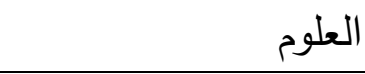 \\
\hline 1990 & السياحة و الفنادق \\
\hline 1991 & الطب \\
\hline$r \ldots r$ & الاداب \\
\hline$r \ldots r$ & الحاسبات و المعلومات \\
\hline$r \ldots r$ & رياض الاطفال \\
\hline
\end{tabular}

و من الجدول السابق نلاحظ ان اقدم المكتبات هى مكتبـة كلية التربية بينما

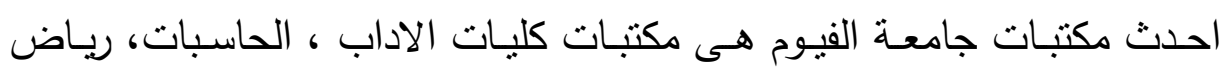

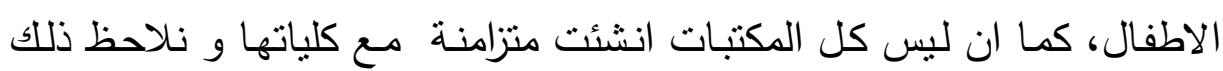

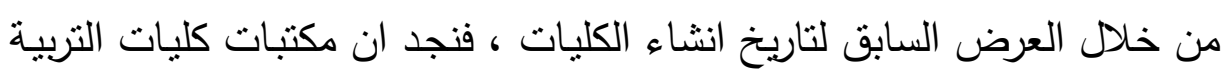

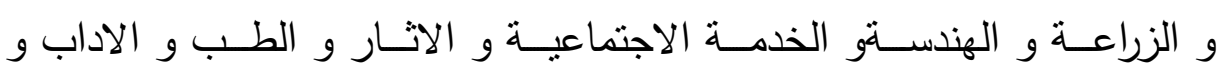

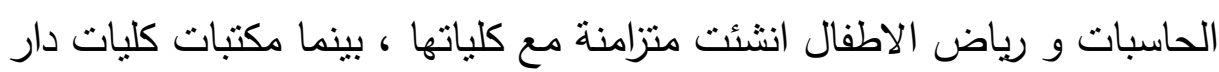

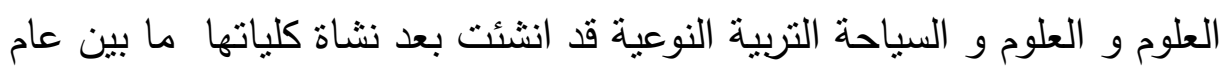

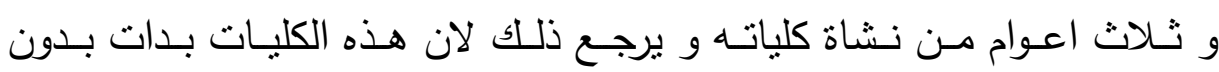

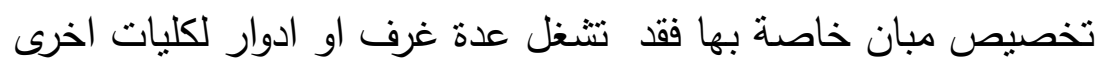
مقتيات مكتبات جامعة الفيوم 
تحتوى مكتبات جامعة الفيوم الثلاثه عشر مكتبة على مختلف اوعية المعلومات و

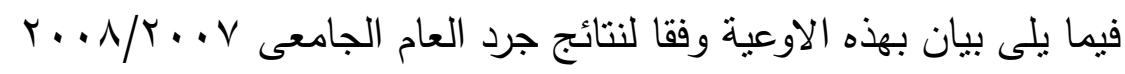

\begin{tabular}{|c|c|c|c|c|c|c|c|c|c|c|}
\hline موسوعة & مؤتمرات & دورية- & فصغر & شرائط & اطلس & قواميس & الرسائل & الاجنبية & العربية & المكتبة \\
\hline & & & & & & Yr & אדYY & $\varepsilon r .$. & $0 \leqslant 71$ & الزراعة \\
\hline & & & & $\varepsilon V$ & 1 & & Tr & rrs. & $\varepsilon r V$ & العلوم \\
\hline & & & & 10 & $r$ & & & $\varepsilon r_{0}$ & $\varepsilon$ & الطب \\
\hline & & & & & & & 174 & 0.0. & V৭V & الهندسة \\
\hline \multirow[t]{2}{*}{1} & & 1001 & & & $r$. & $M \mid$ & זדו & V7. 0 & IVotr & التربية \\
\hline & & & & & & & $09 V$ & 1070 & qV०V & الخدمة \\
\hline \multirow[t]{3}{*}{ Y $\varepsilon$} & $\leq 7$ & $1 \leqslant 0$ & & & & 10. & rTr & & $11 \leq 74$ & دار علوم \\
\hline & & & v. & $\varepsilon 9$ & & & or & 1010 & $r r \leqslant q$ & السياحة \\
\hline & & & & & & & rᄉ & NIr & $\wedge r \wedge \wedge$ & النوعية \\
\hline \multirow[t]{4}{*}{ ITE } & & 149 & & & ro & Tr & ᄉTV & lorv & rqVi & الاثار \\
\hline & & & & & & & $r$ & $\wedge$. & 017 & الاداب \\
\hline & & & & & & & & $1{ }^{1}$ & 0 & الحاسبات \\
\hline & & & & & & & & & r4T & رياض \\
\hline
\end{tabular}

نلاحظ من الجدول السابق ان مكتبات جامعة الفيوم تشتثل بنسبة كبيرة على القى

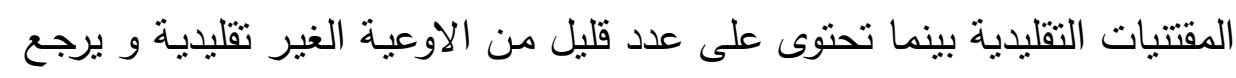

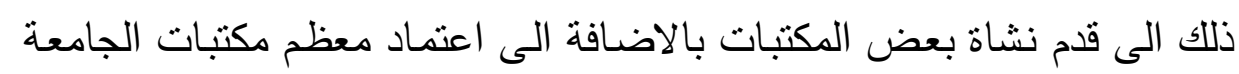

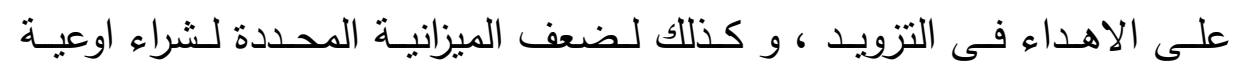
المعلومات و لا سيما مع ارتفاع تكلفة شراء الاوعية الغير تقليدية.

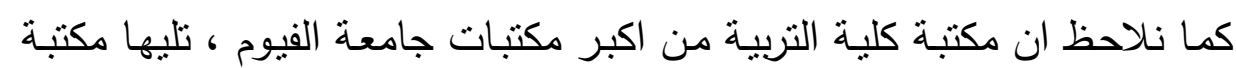

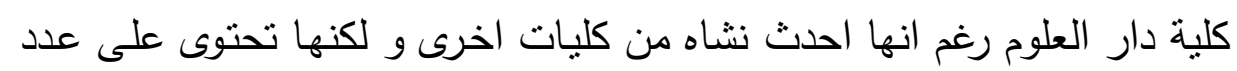

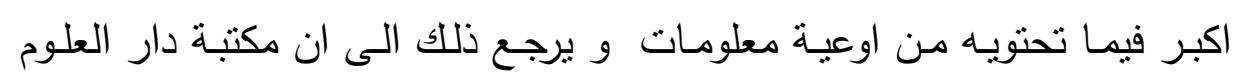
v 
تهتم بمصادر المعلومات فى اللغة العربية و العلوم الاسـامية و هى ثانى كلية على مستوى الجامعات المصرية فى هذا التخصص .

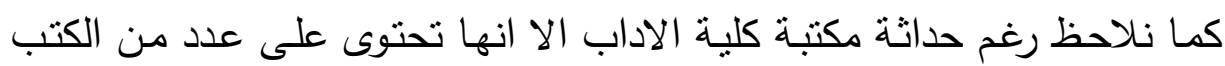

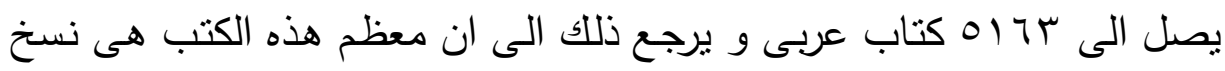
وليس عناوين ، بالاضافة الى اعتمادها على الاهداء و قبولها للكتب دون تقييم

تميـز مكتبـات كليـات السياحة و دار العلـوم باقتتــاء انـواع مميـزة مـن اوعيـة

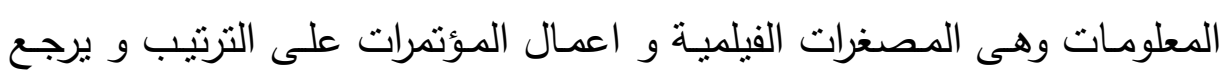
ذللك وفقا لما تقتضيه طبيعة الدراسة فى كلية السياحة و الى حرص ادارة الكلية

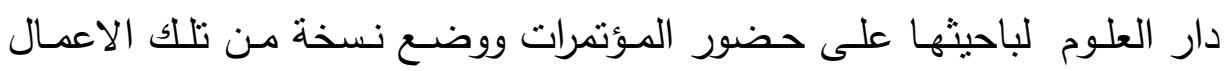

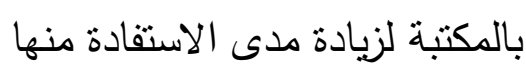

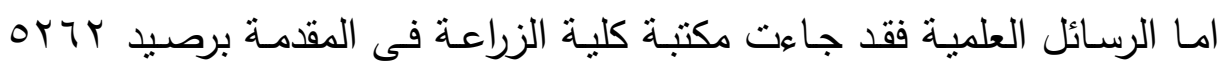

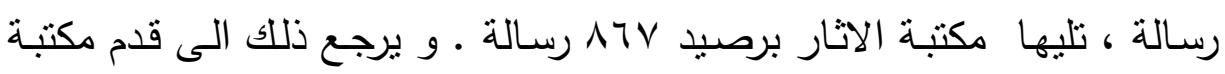

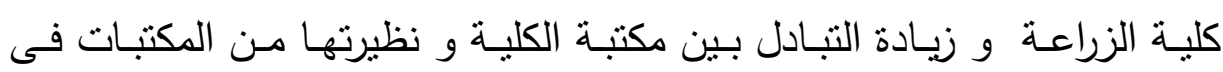

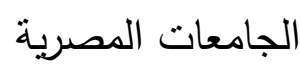

\section{العمليات الفنبة في مكتبات جامعة الفيوم:}

تقوم مكتبات جامعة الفيوم بتتظيم مقتتياتها باعداد فهارس بطاقية باسماء المؤلفين

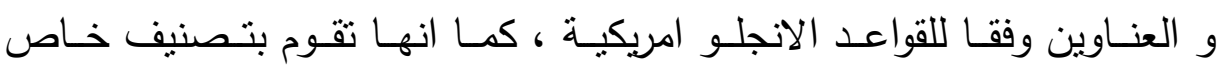
لمقتنياتها وفقا للاقسام العلمية بكل كلية

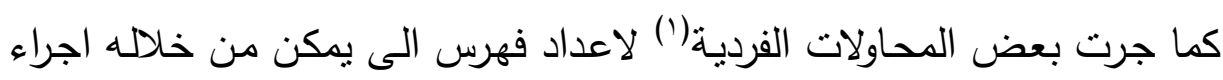

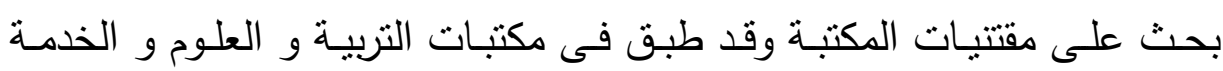
الاجتماعية r(r)

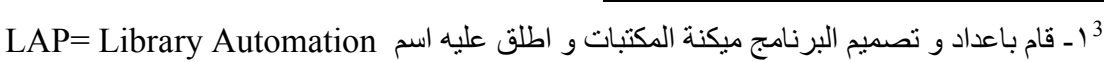

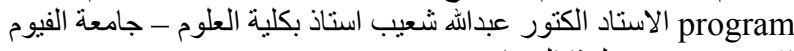




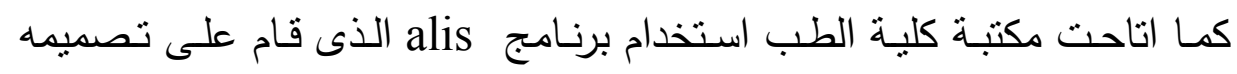
مركز معلومات و دعم اتخاذ القرار بمجلس الوزراء

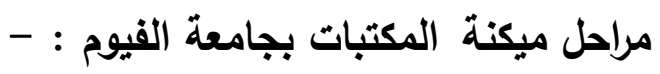

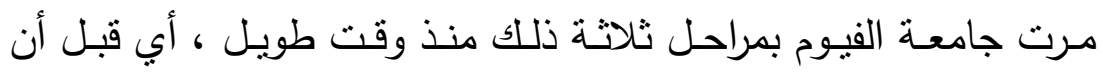

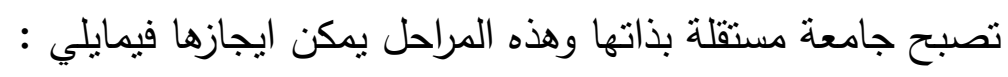
ا ا. مرحلة الإستعانة بالجهات الرسمية في الميكنة .

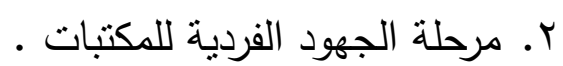

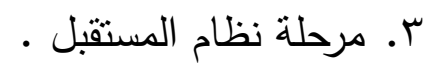

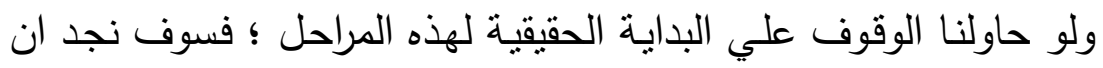
المرحلتين الأولى والثانية قد صاروا فى نفس الوقت معا ؛ ففي الوقت الذي كانت فيه مكتبات داخل الجامعة تقوم بتطبيق نظام من مركز المعلومات ودعم أنخاذ

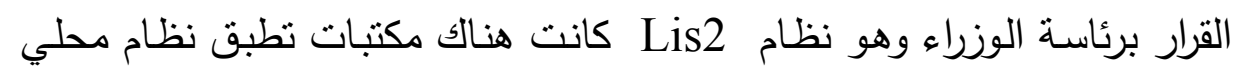

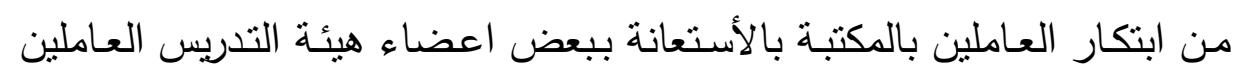
بتخصص الحاسب الآلى ولغات البرمجة .

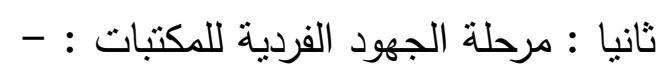

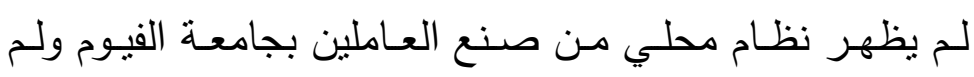
يستخدم الإفي مكنبة كليتين ، هما مكتبة كلية العلوم ثم مكتبة كلية

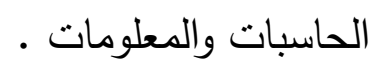

انثاء هذا النظام منذ عام .... ب بواسطة لغة برمجة شيئية

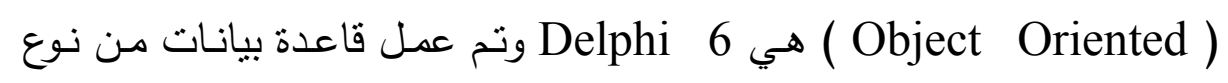
Paradox 7

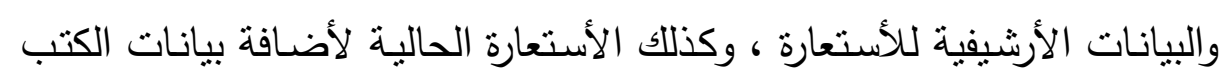

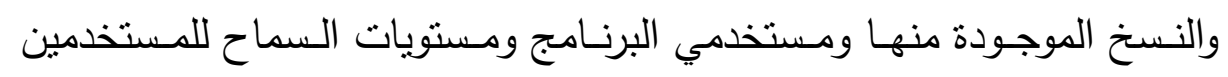

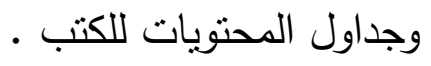


وسـوف نقـوم بـشرح كيفـة عمـل البرنـامج عـن طريـق عـرض الـشاثـات

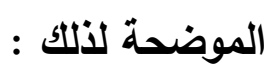

عند تشغيل البرنامج تظهر شاشة الدخول والتى تحظر الدخول إلا للأفراد المسموح لهم ذلك وهم الأفراد الحاصلين علي أسم دخول وكلمة مرور للنظام. هؤلاء الأفراد تمت إضافتهم سلفا من قبل أمين المكتبة أو من بنوبه عنه (انظر

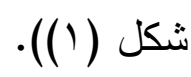

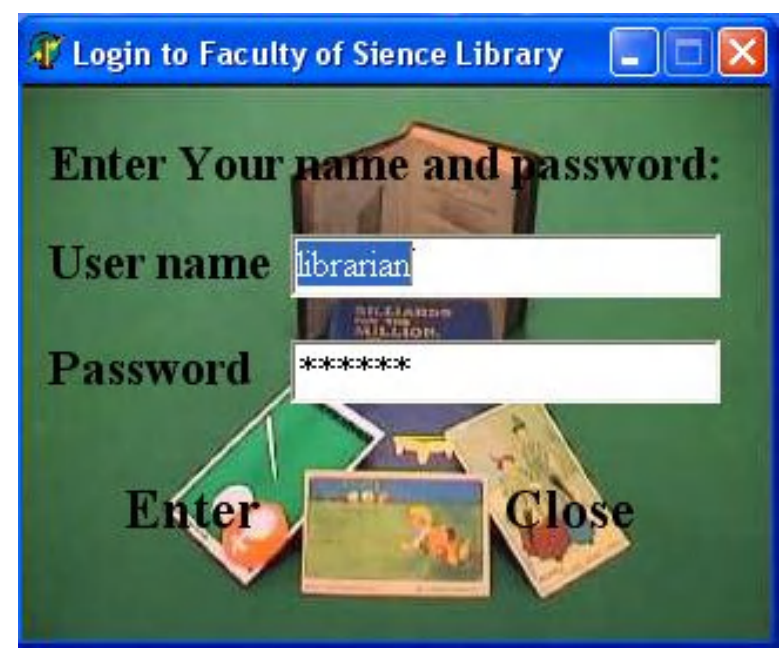

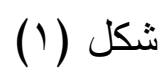

يتم تحديد مستوى الحماية الذى سيتم تطبيقه بعد الدخول للنظام تبعا لإسم المستخدم. إذا كان اسم الدخول لأحد الباحثين فيتم السماح له بالبحث فقط أما إذا كان الاسم لأمين المكتبة مثلا فيسمح له بالبحث والاضافة والحذف والتعديل وبقية الامكانيات التى يوفرها البرنامج. بعد الدخول تظهر الثاشة الرئيسية للبرنامج (انظر شكل (r)) 


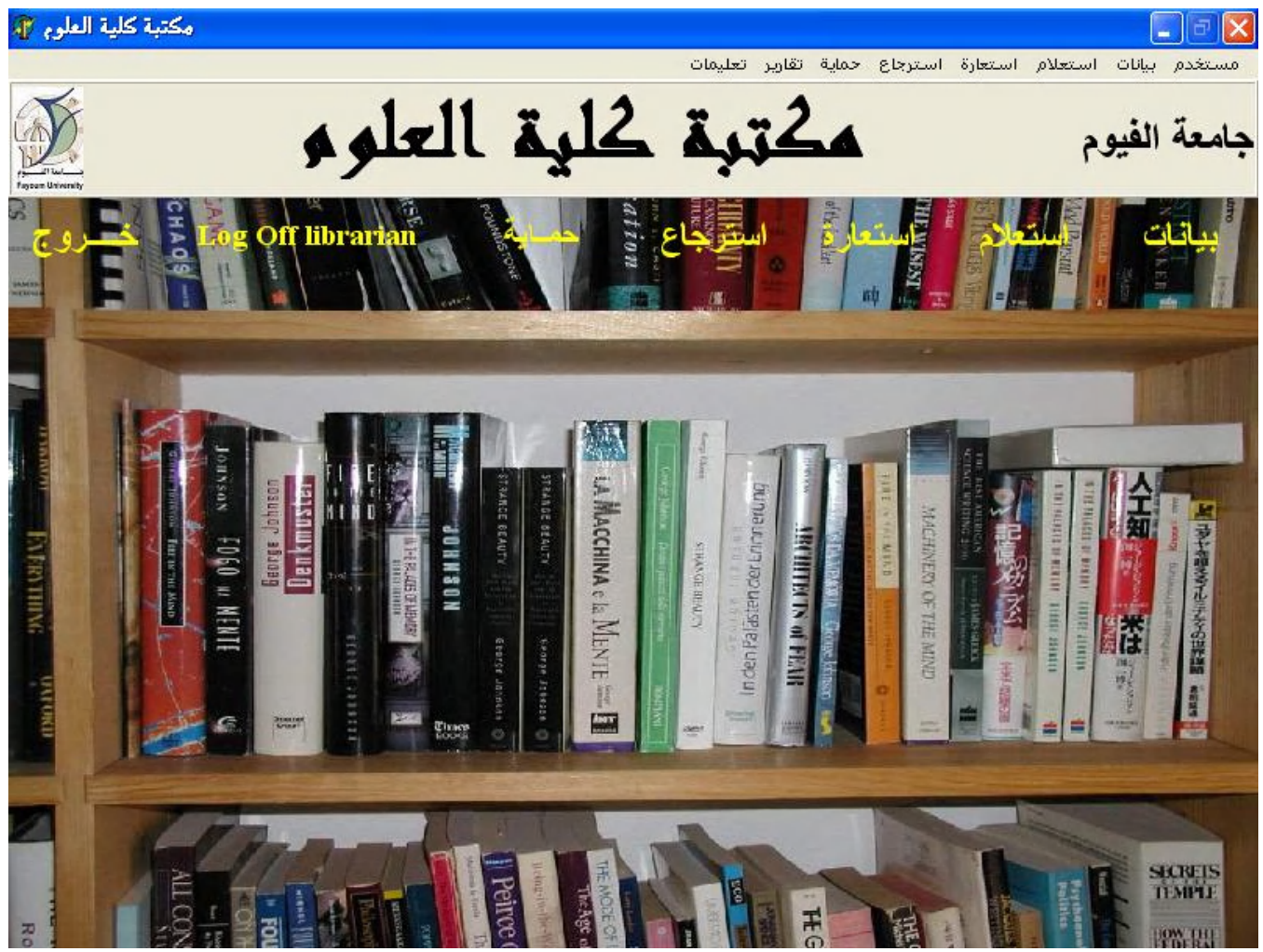

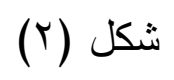

وهذه الثاشة تحتوي على كل أمكانيات البرنامج وطرق الدخول اليها ، فهي بوابة

الدخول لعمل كل الأجراءات داخل المكتبة . 
وينقسم النظام إلى عدة أقسام : - م

(أولا) بيانات

وفى هذا القسم يتم إضافة بيانات كاملة لكل كتاب ومستعير وتخصص

رئيسي وفرعي ، وهنا يتم إدخال كافة بيانات الكتاب داخل بطاقة فهرسة

الالكترونية، مماثله لبطاقة الفهرسة الورقية التي كانت تستعمل داخل الدكتبات

وتتشمل علي ثلاثة عناصر هما : -

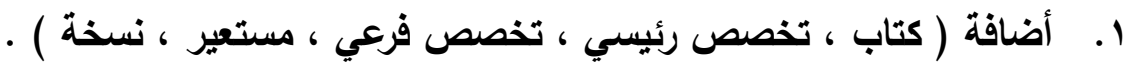

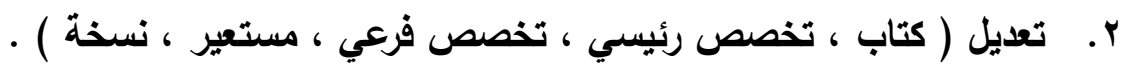

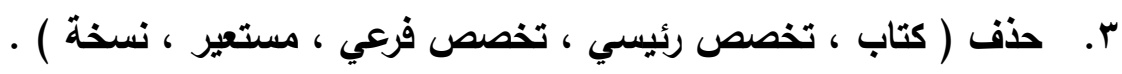

-

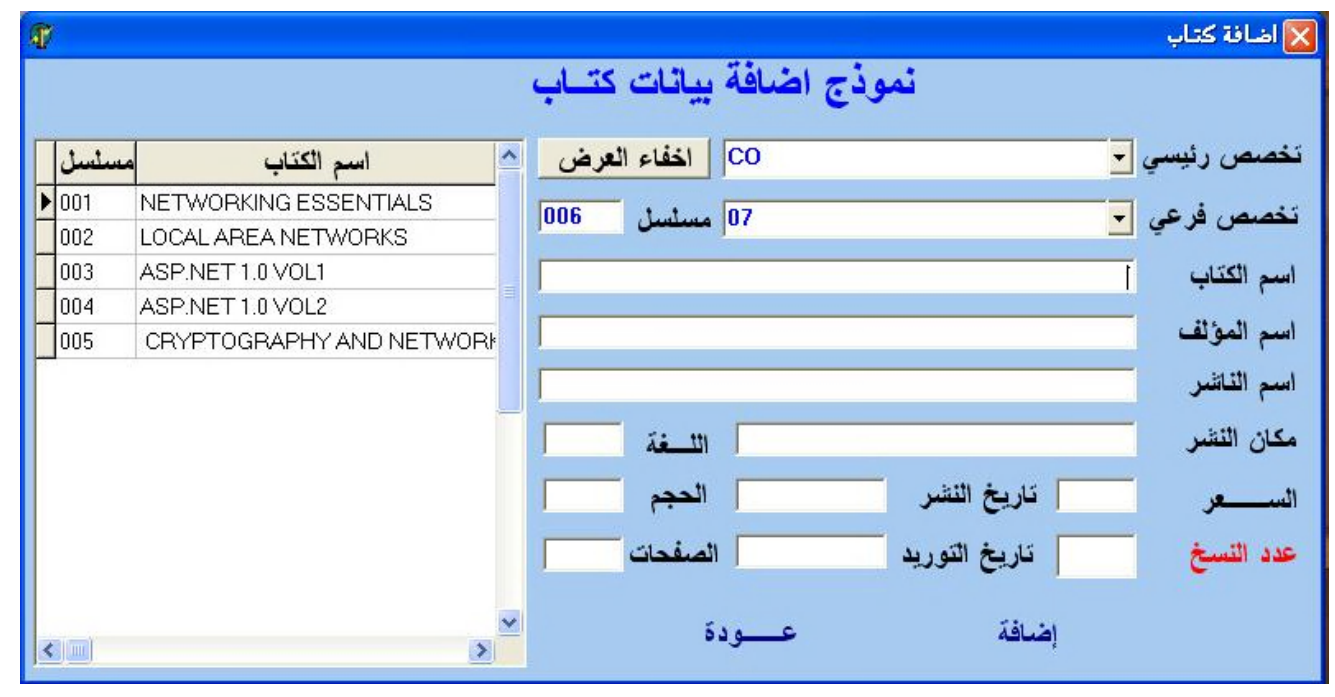

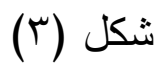




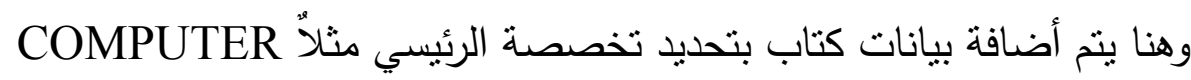

ويرمز له بحرفين CO ثم التخصص الفرعي داخل التخصص الرئيسي وهتا

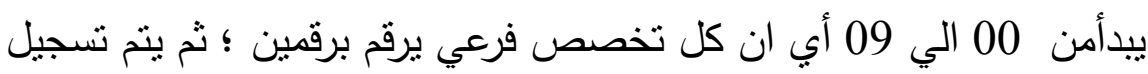

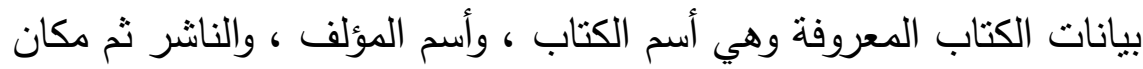

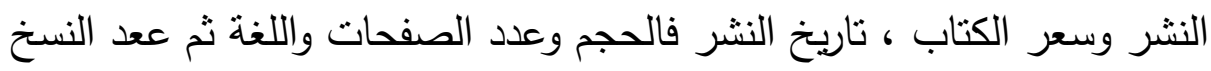

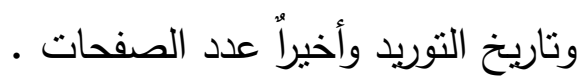
ثم بعد أضافة هذة البيانات يعطي شاثة أخري اضافية يتم أضافة الرقم العام بها

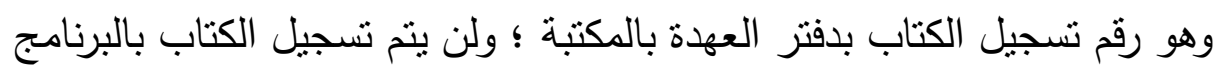

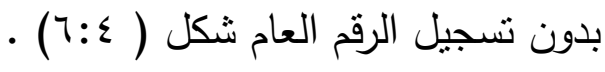

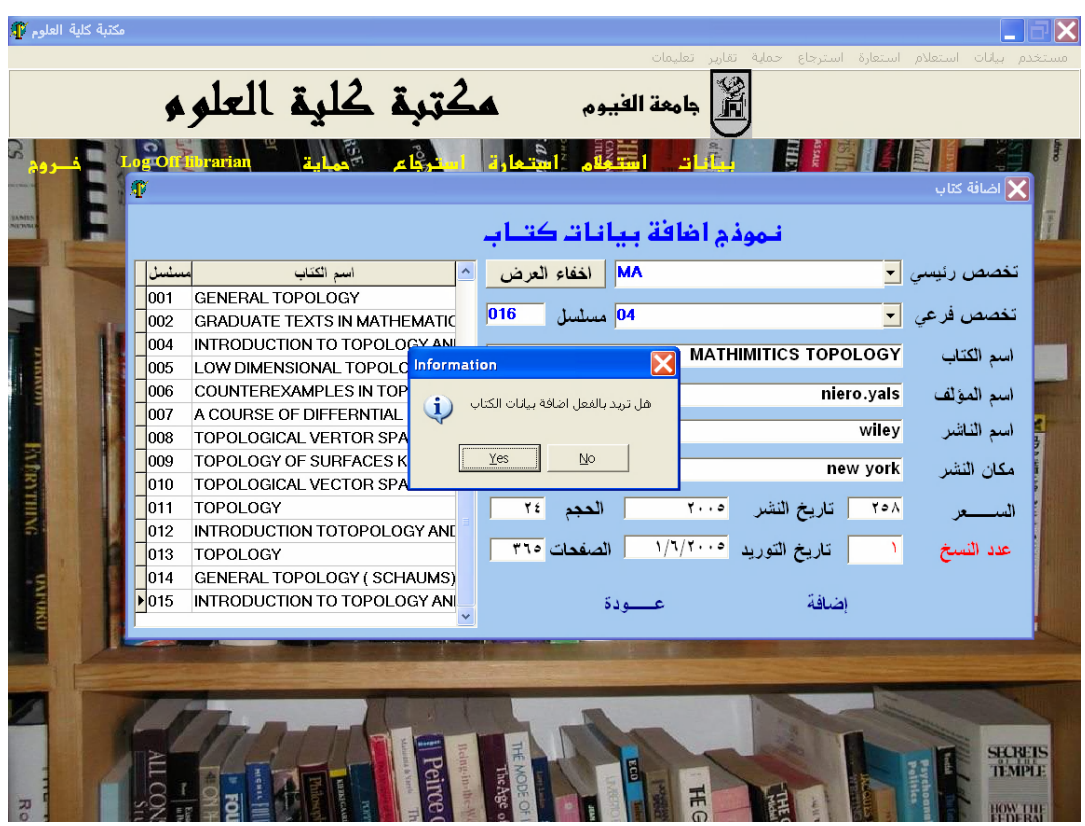

( ) 


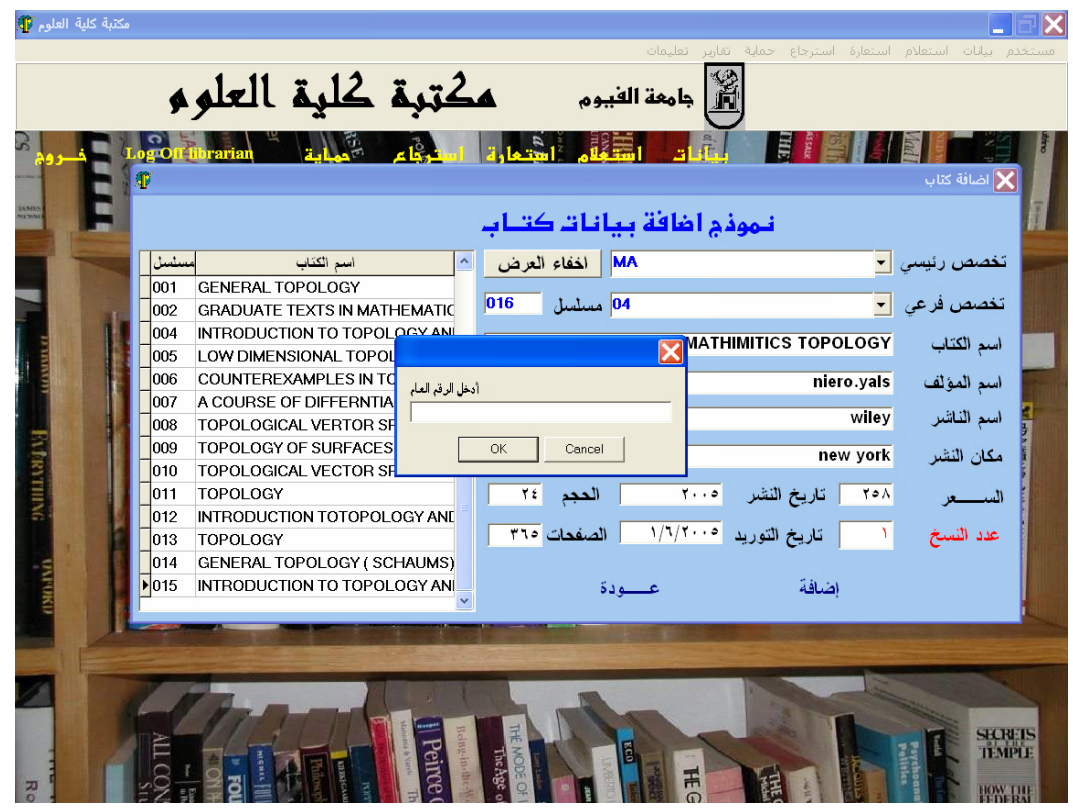

$$
\text { شكل ( ) }
$$

لأبد من أدخال الرقم العام للكتاب وهو رقم العهدة بالمكتبة ولن يقبل البرنامج

تسجيل الكتاب الأ بعد تسجيل الرقم العام شكل (9) •

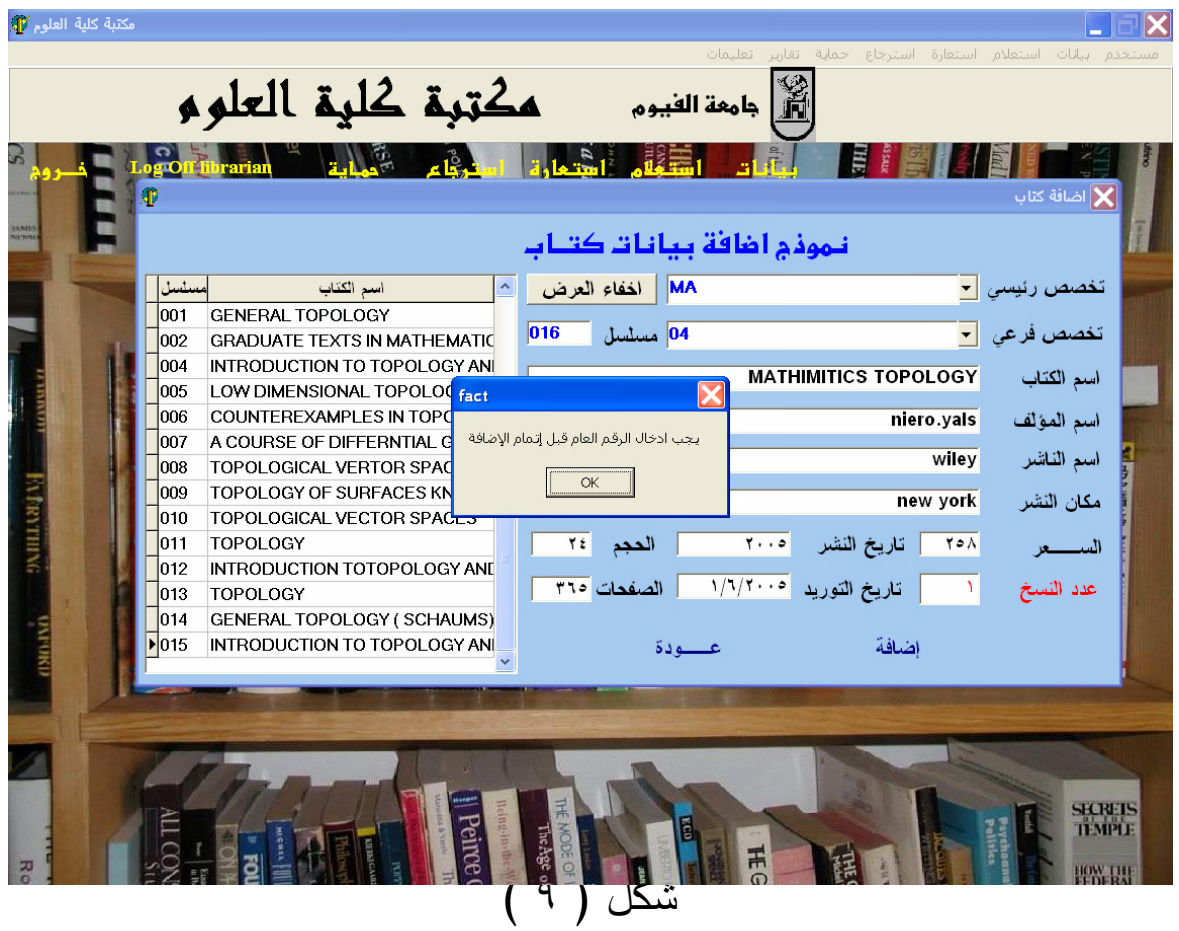


أضافة نسخة من كتاب موجود من قبل :

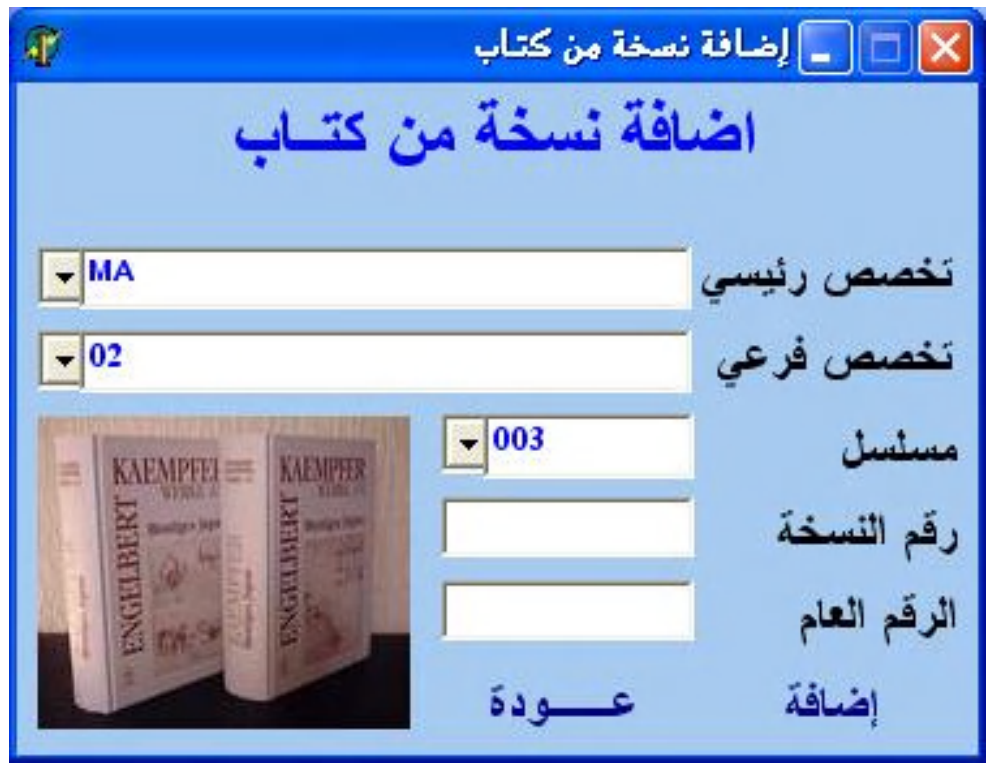

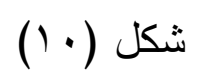

وهنا يمكننا أضافة نسخة من كتاب موجود بالفعل ؛ ويتم فية تحديد التخصص الرئيسي والفرعي ومسلسل الكتاب الموجود ورقم النسخة الجديدة ثم الرقم العام وهنا يعطي رسالة أن الأضافة تمت كما في أي مرحلة أضافة تظهر هذه الرسالة 


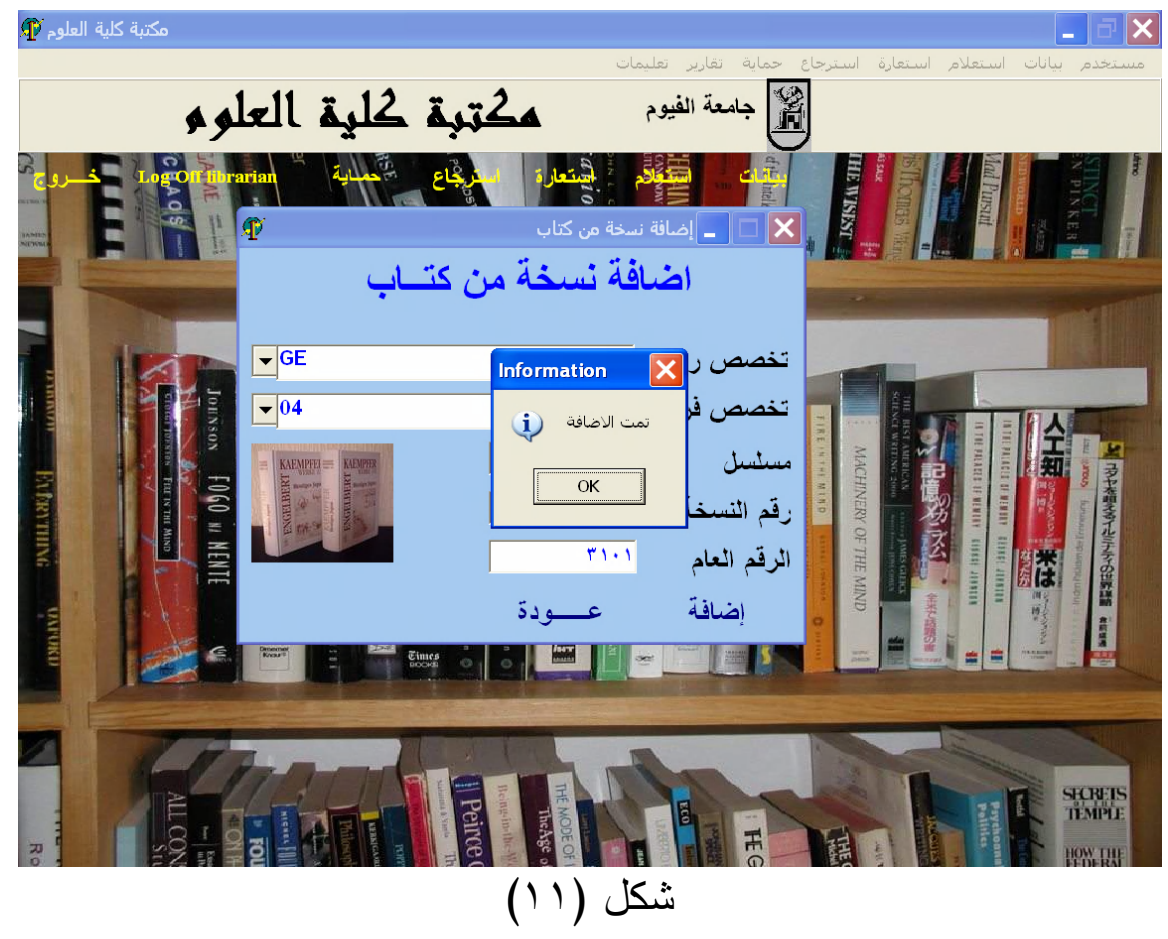

رسـالة ( تمت الأضـافة ) تظهر عند أضـافة كتاب ، نسخة جديدة من كتاب ،

تخصص رئيسي ، تخصص فرعي ، ومستعير ·

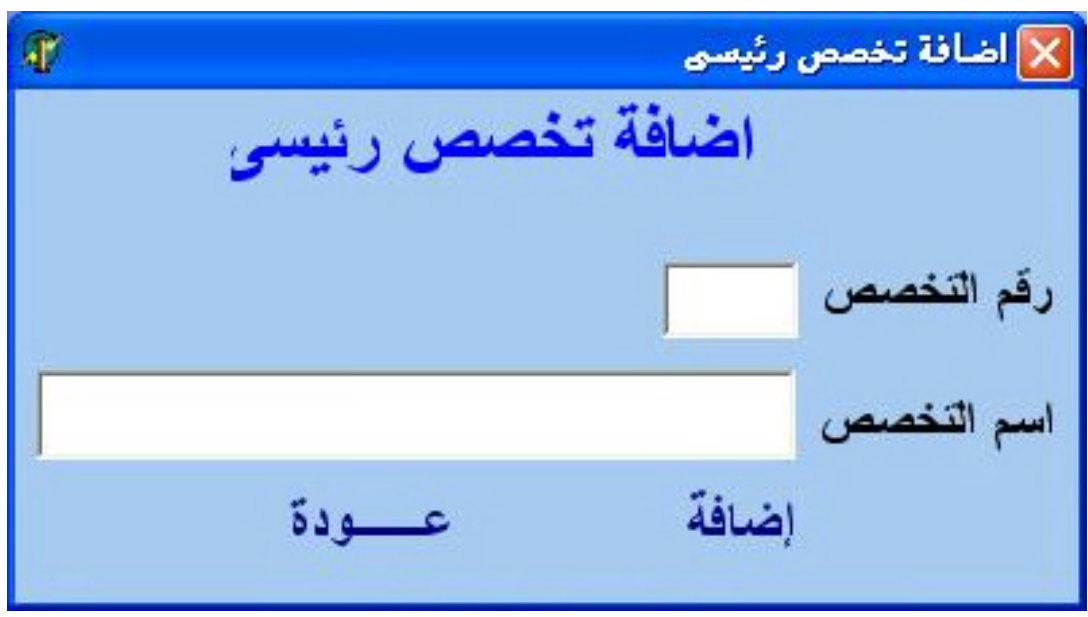

شكل (Y) 


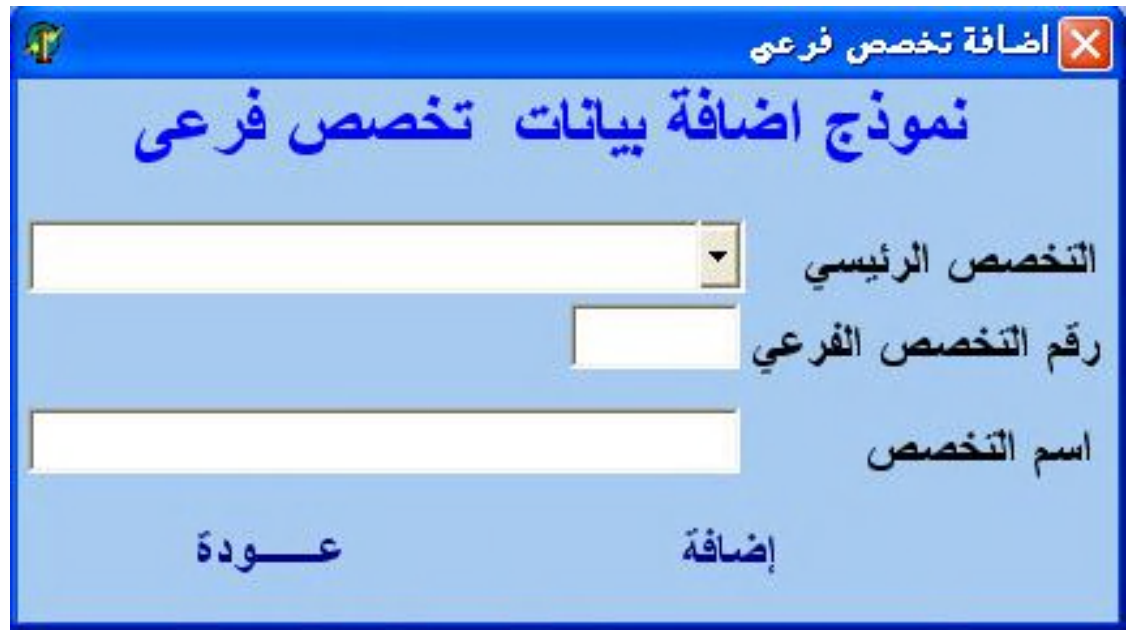

شكل (T)

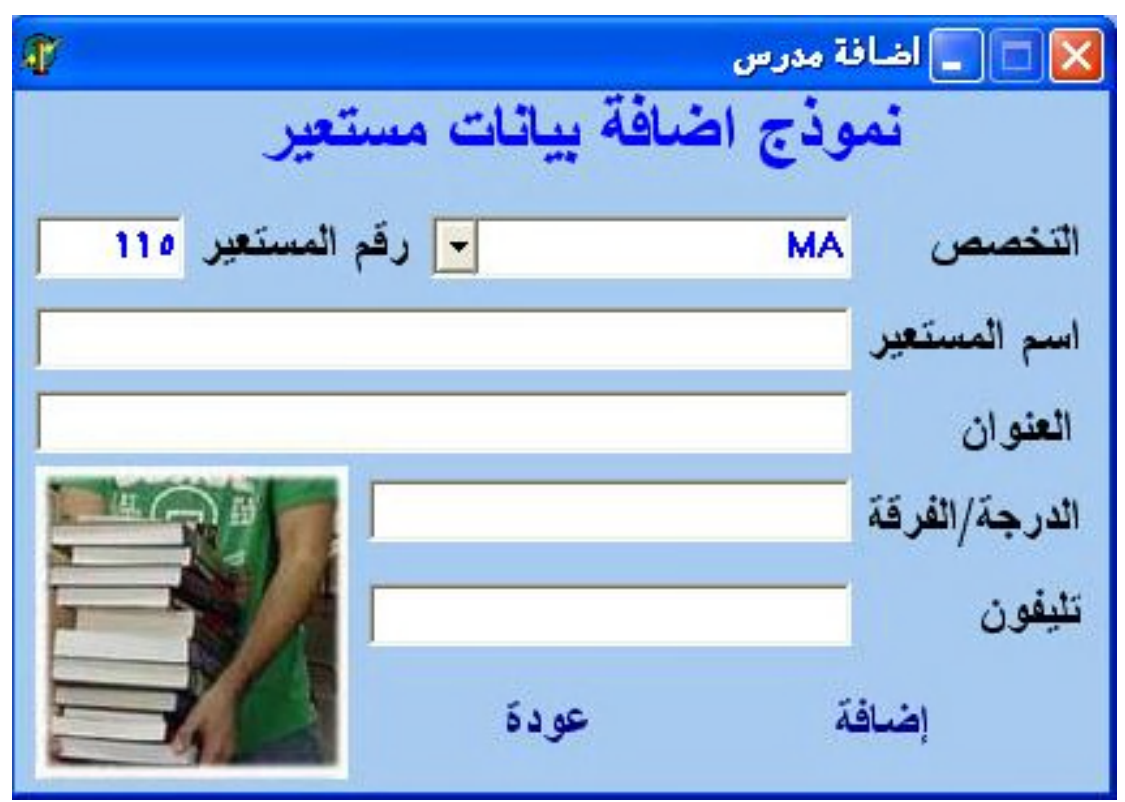

شكل (ع ()) 
- : التعدبل - r

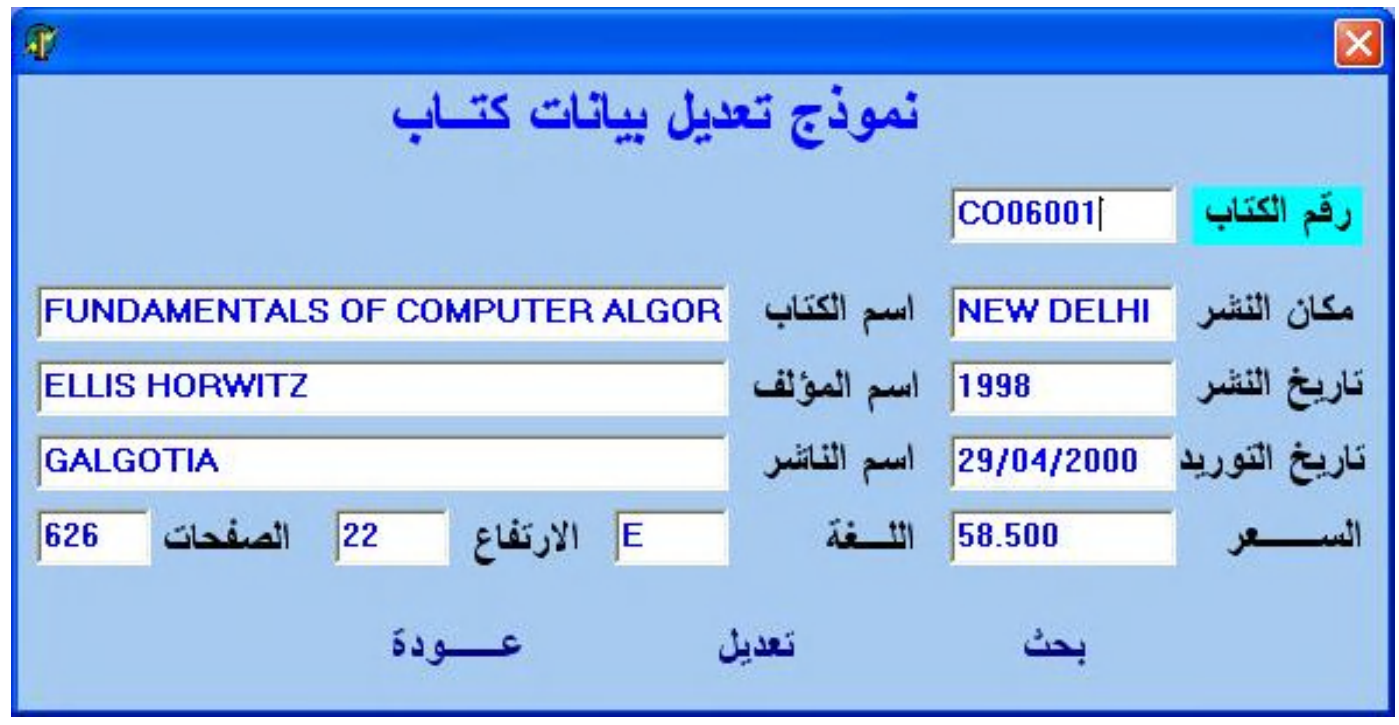

شكل (10) 


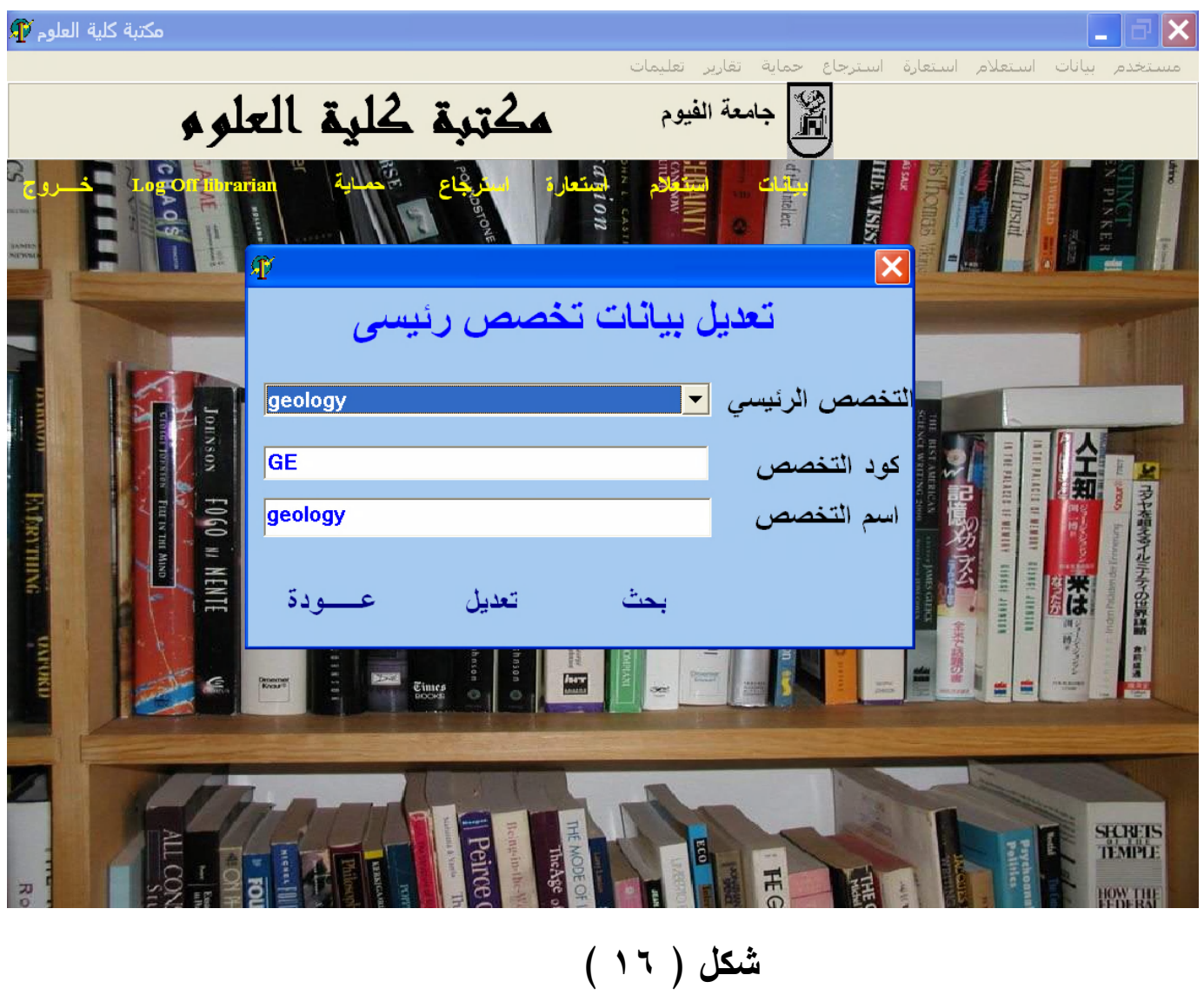




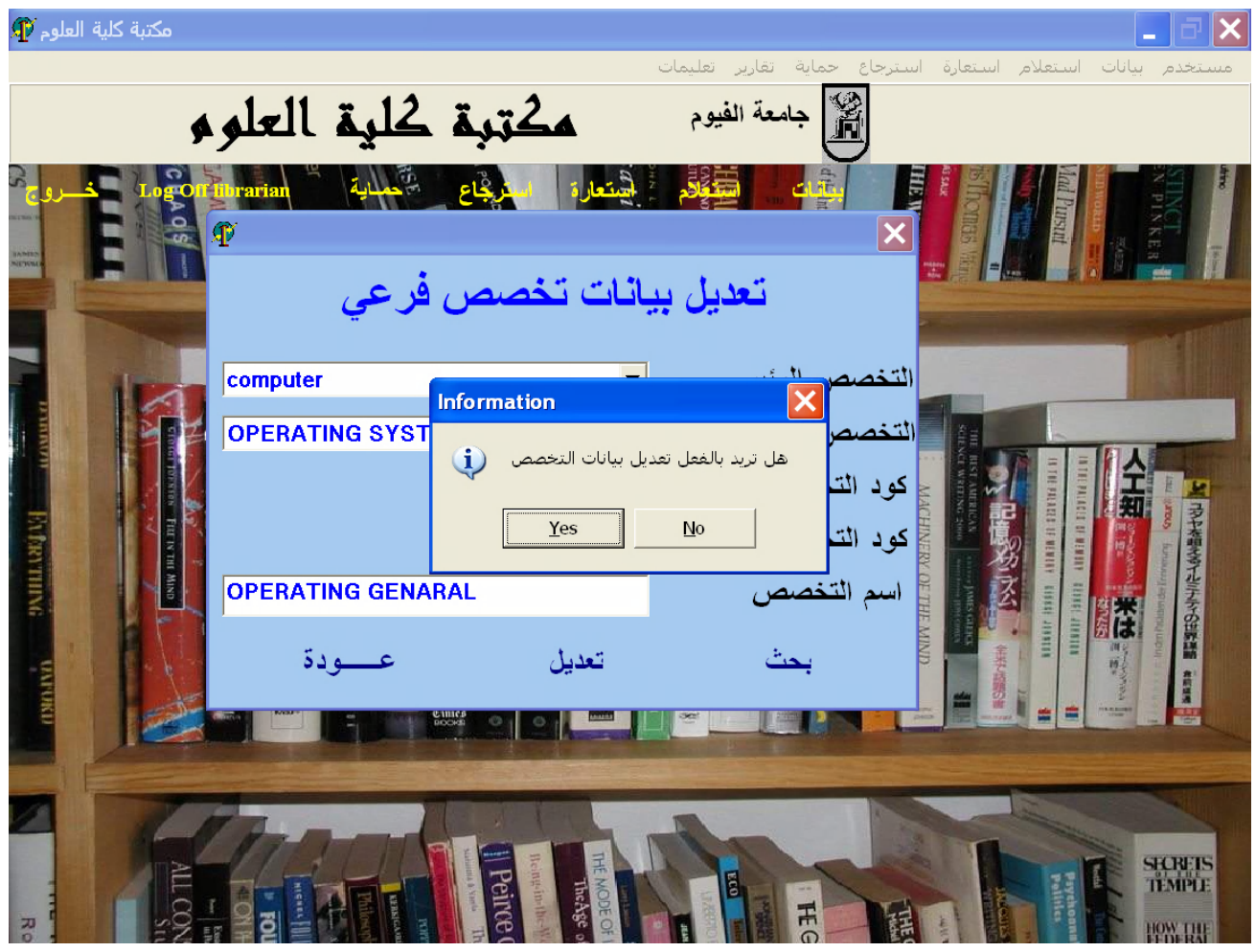

$$
\text { شكل ( IV ) }
$$




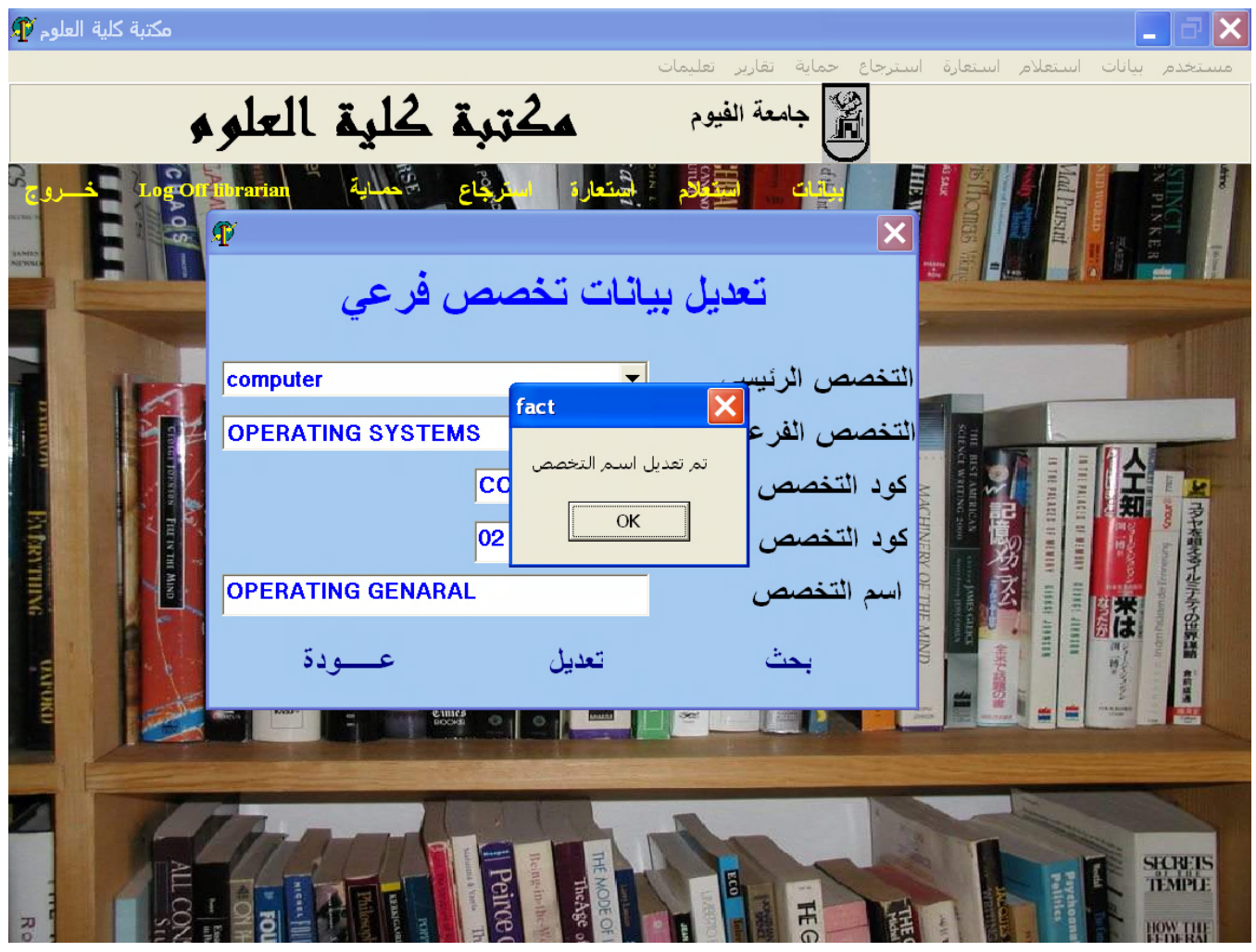

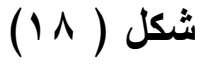




$$
\text { - ب - الحذف - }
$$

ويتم فية حذف كتاب أونسخة من كتاب أو تخصص رئيسي أو فرعي أو

- مستعير

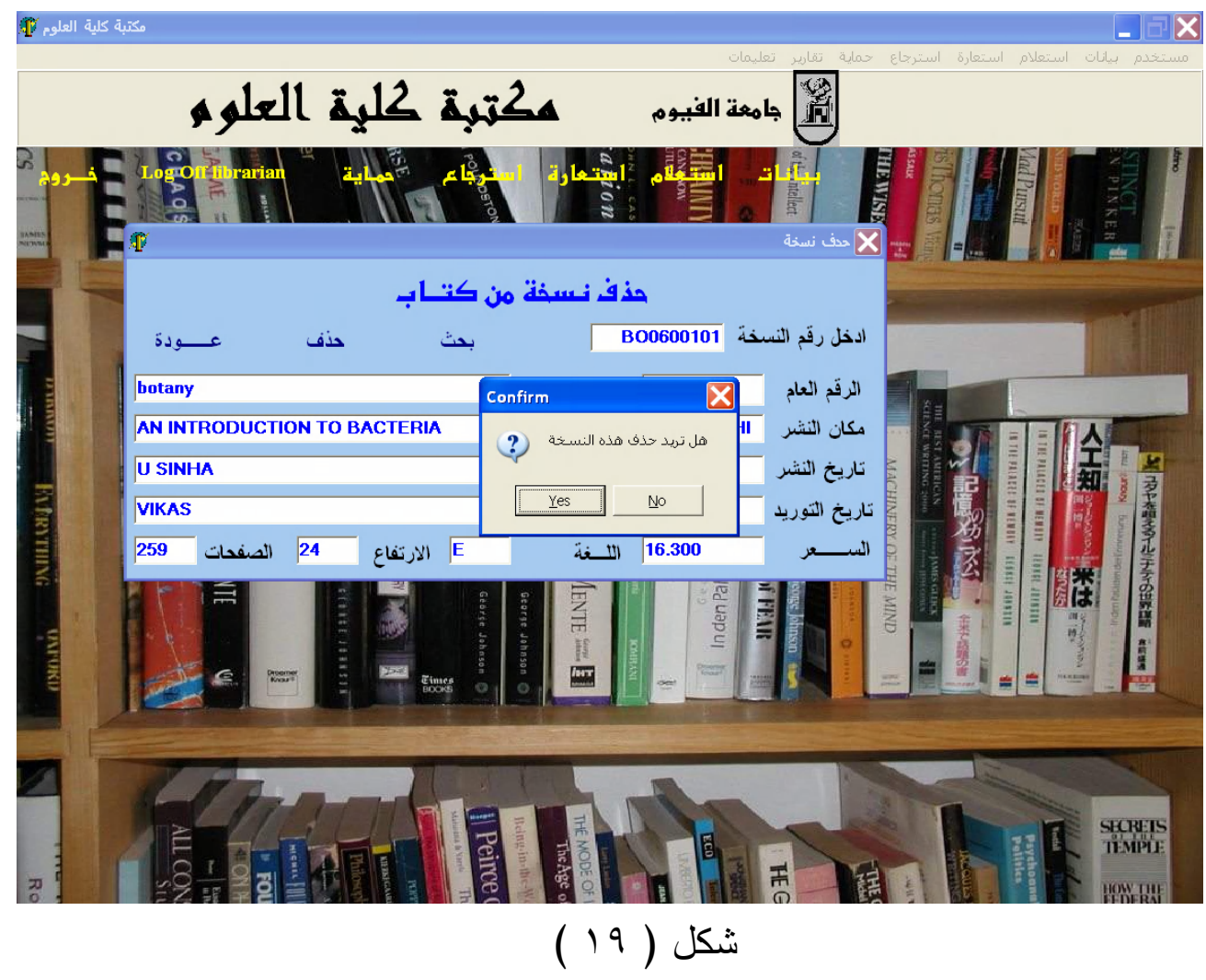

تظهر رسالة تأكيد ( هل نريد حذف هذه النسخة ) فعند الأجابة بـا تختفي هذه الشاشة وعند الأجابة بنعم تحذف نسخة الكتاب ثم تأتي رسالة اخري تقول للك (هل تريد حذف الكتاب نهائيا) وعند الأجابة بنعم فيعني هذا ان الكتاب ونسخة تمت حذفها امـا اذا كانت الأجابـة بـلا فلن تحذف الأ النسخة فقط لكن الكتاب 


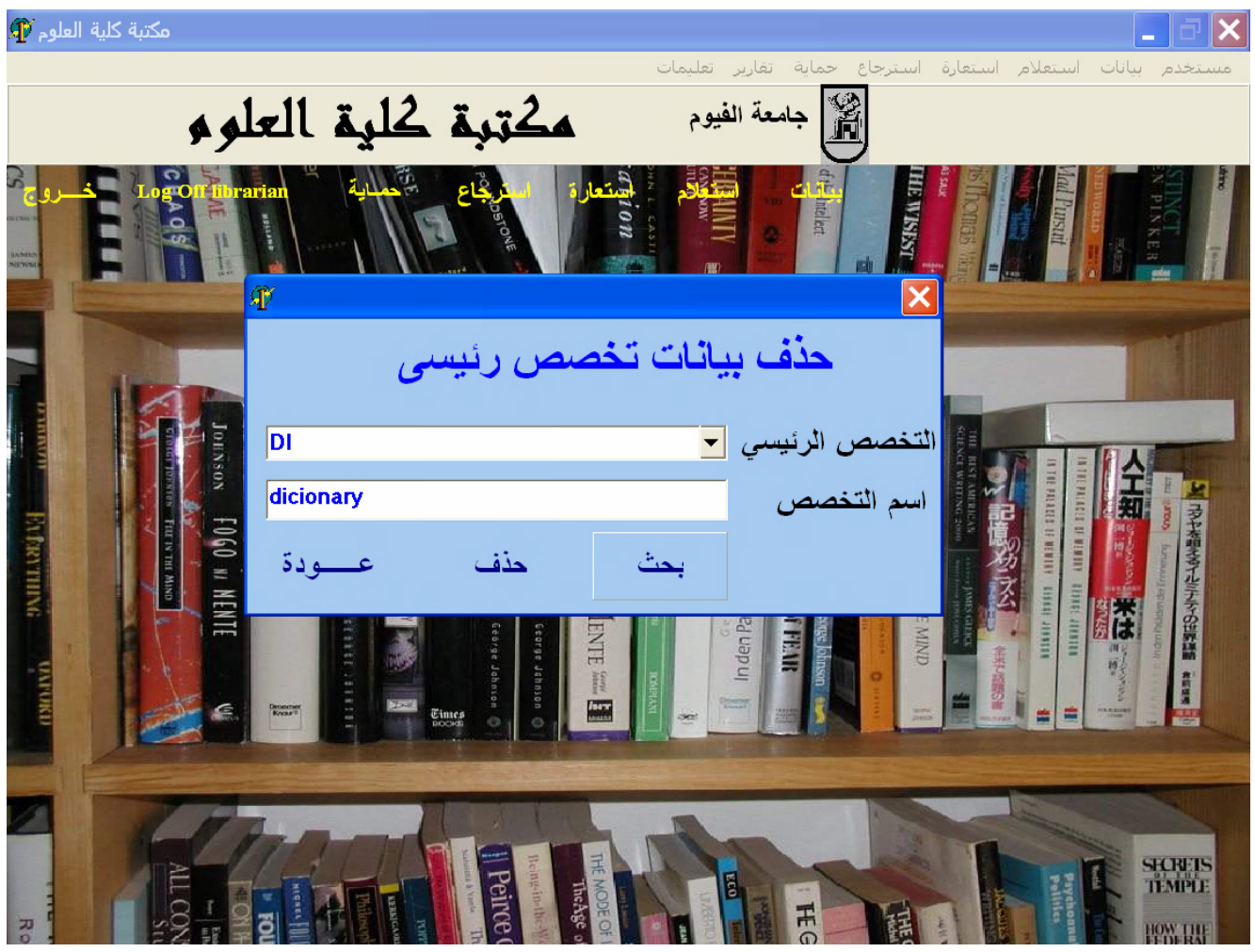

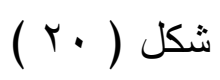




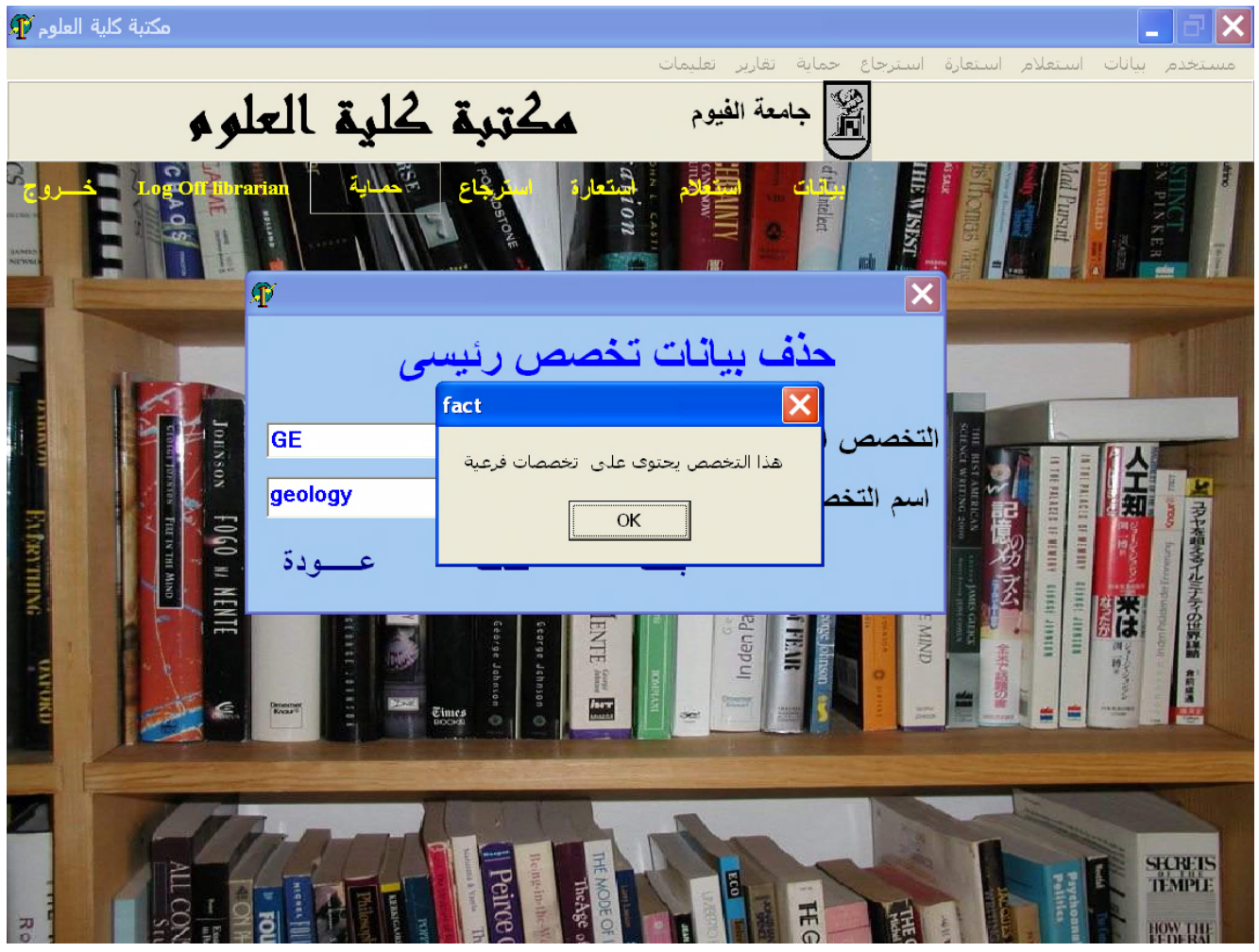

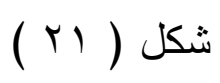

عند حذف تخصص رئيسي فيسأل النظام اذا كان هذا التخصص يحتوي علي تخصصات فرعية مطلوب حذفها ام لا . 


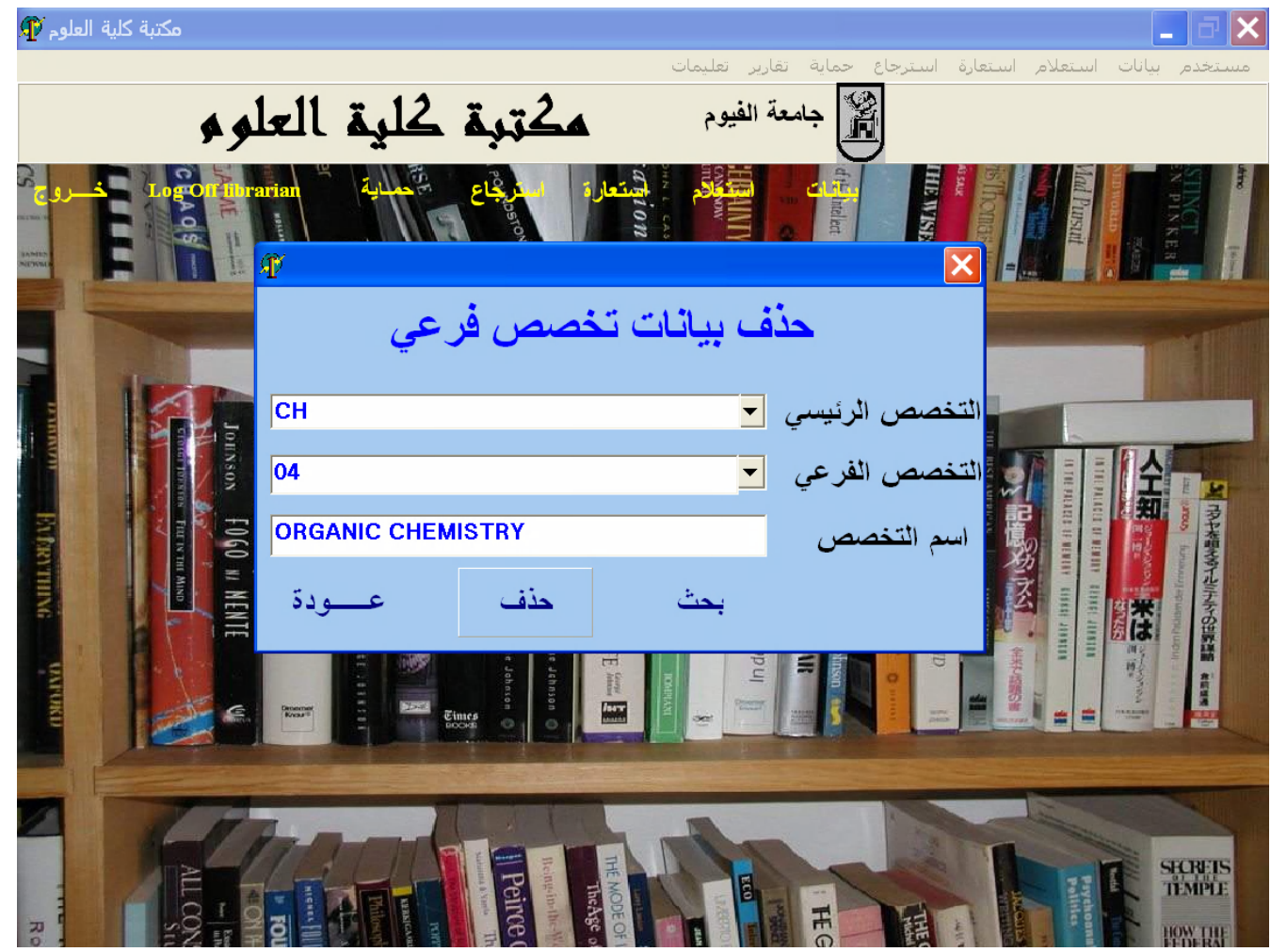

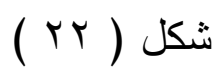




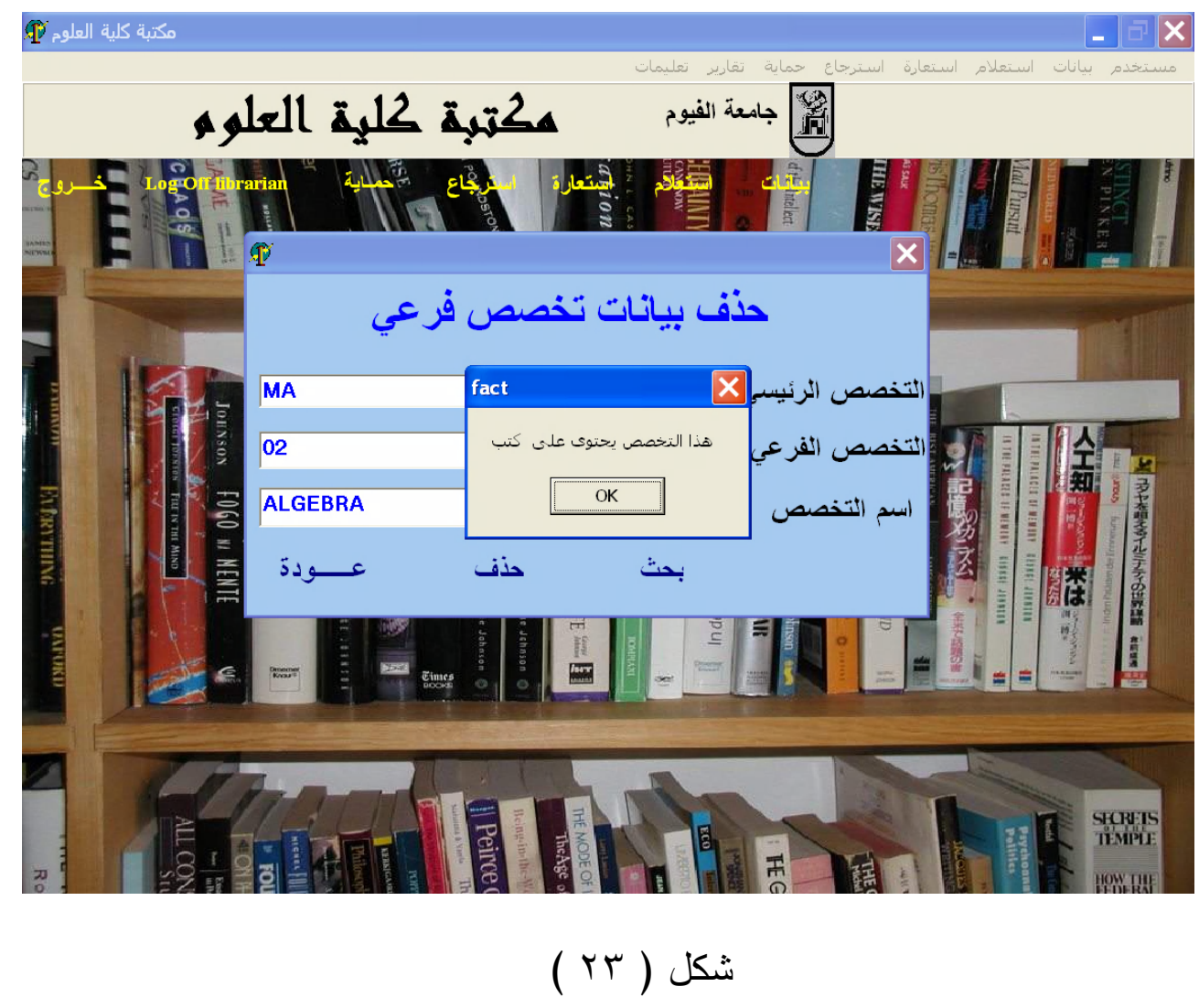

وهنا يتسأل ايضا النظام اذا كان التخصص الفرعي يحتوي على كتب بداخلة سوف يتم حذقها كاملة . 

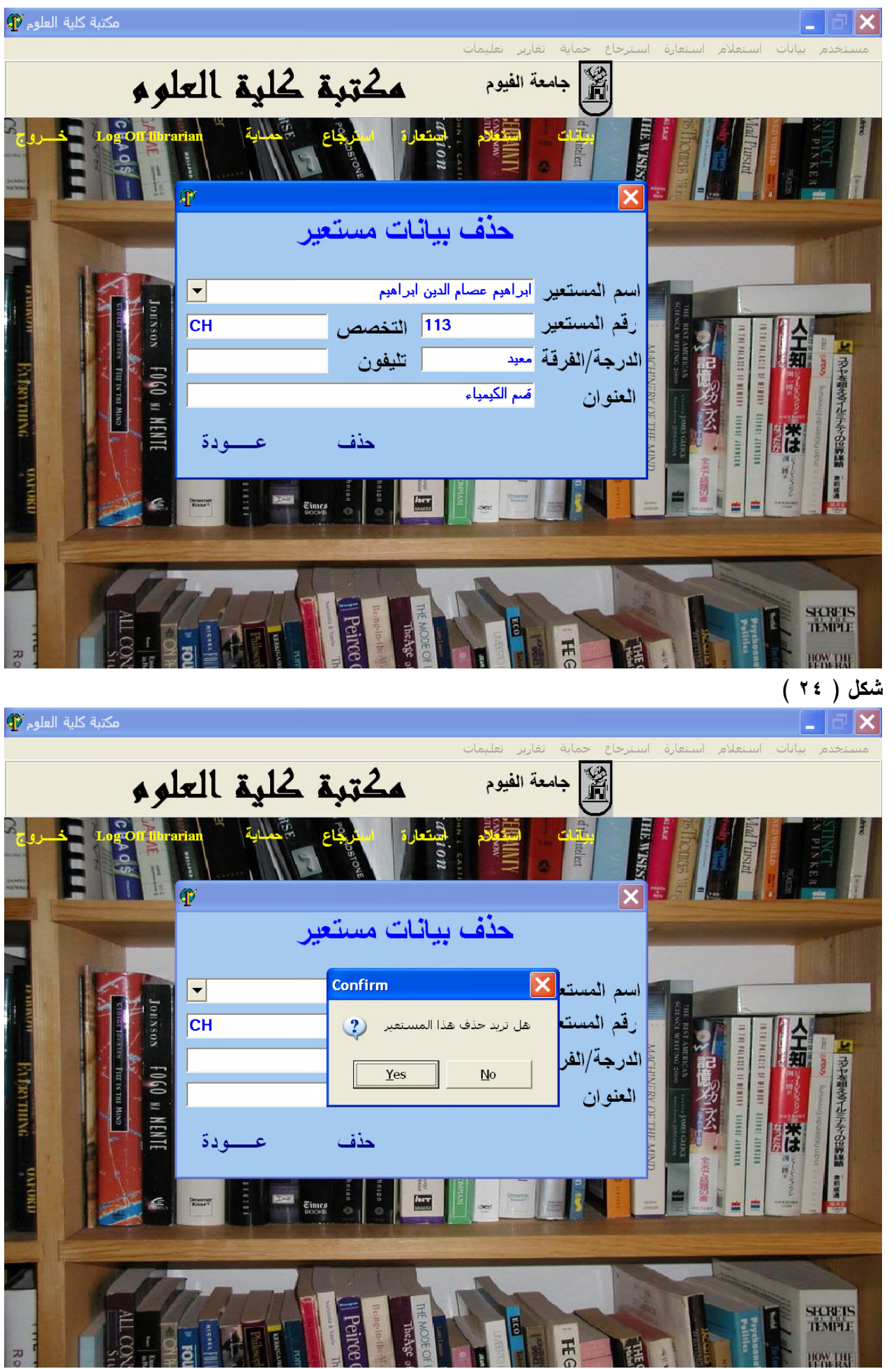


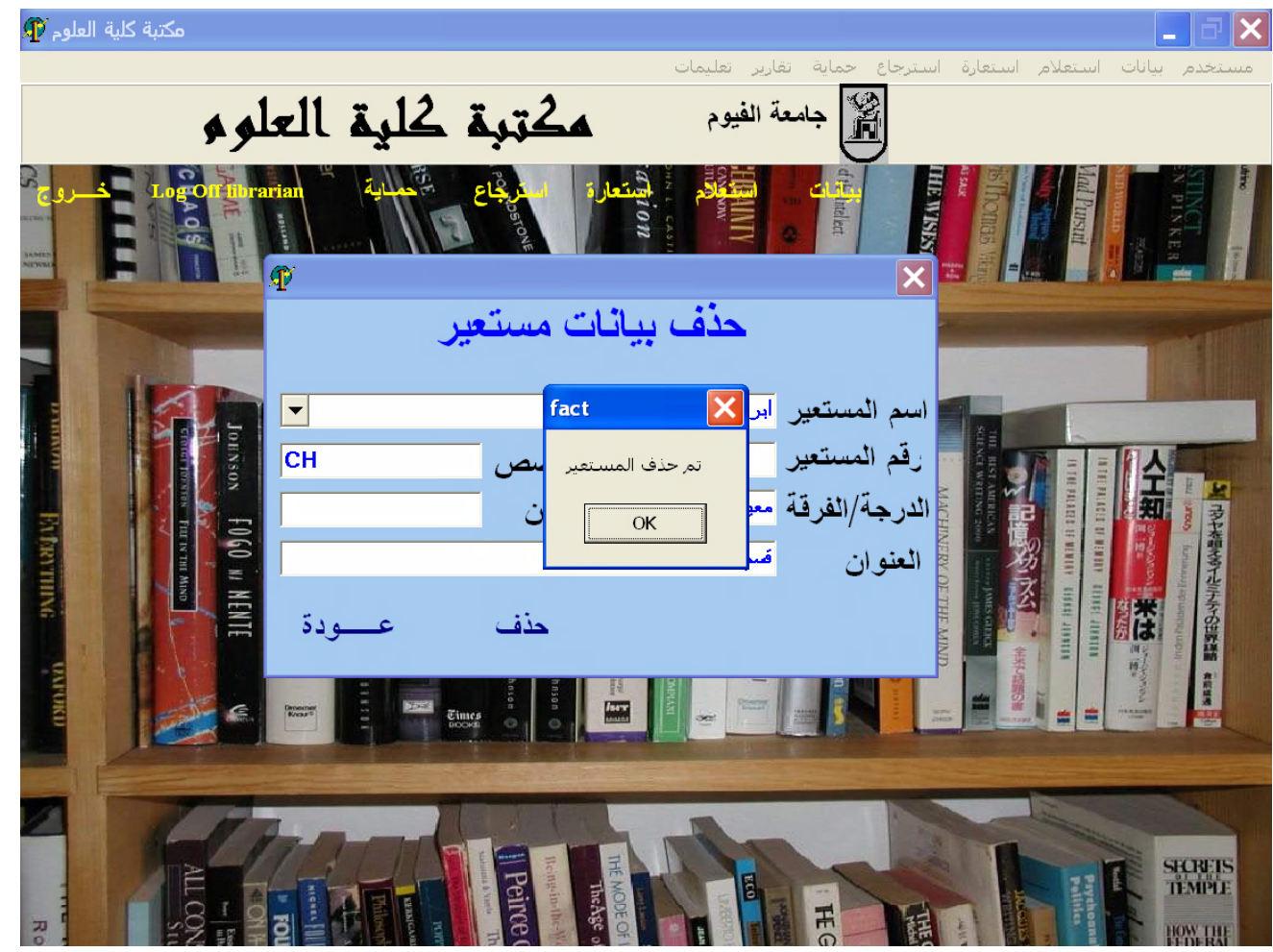

شكل ( דr )

(ثانيا) استعلام:

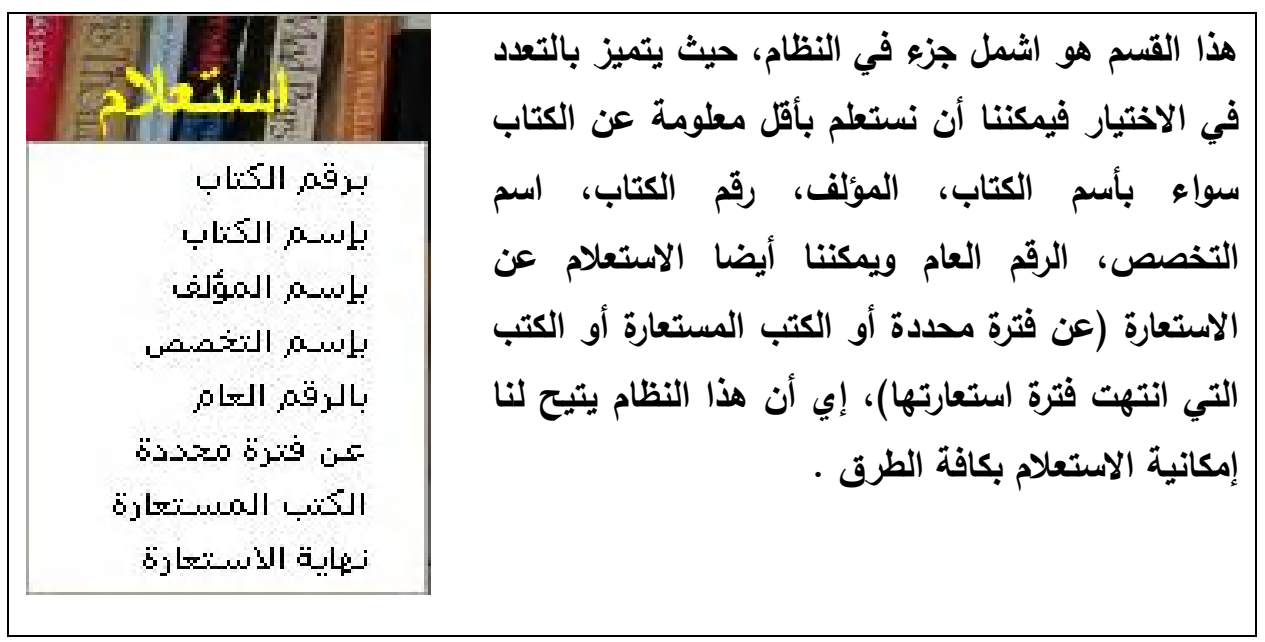




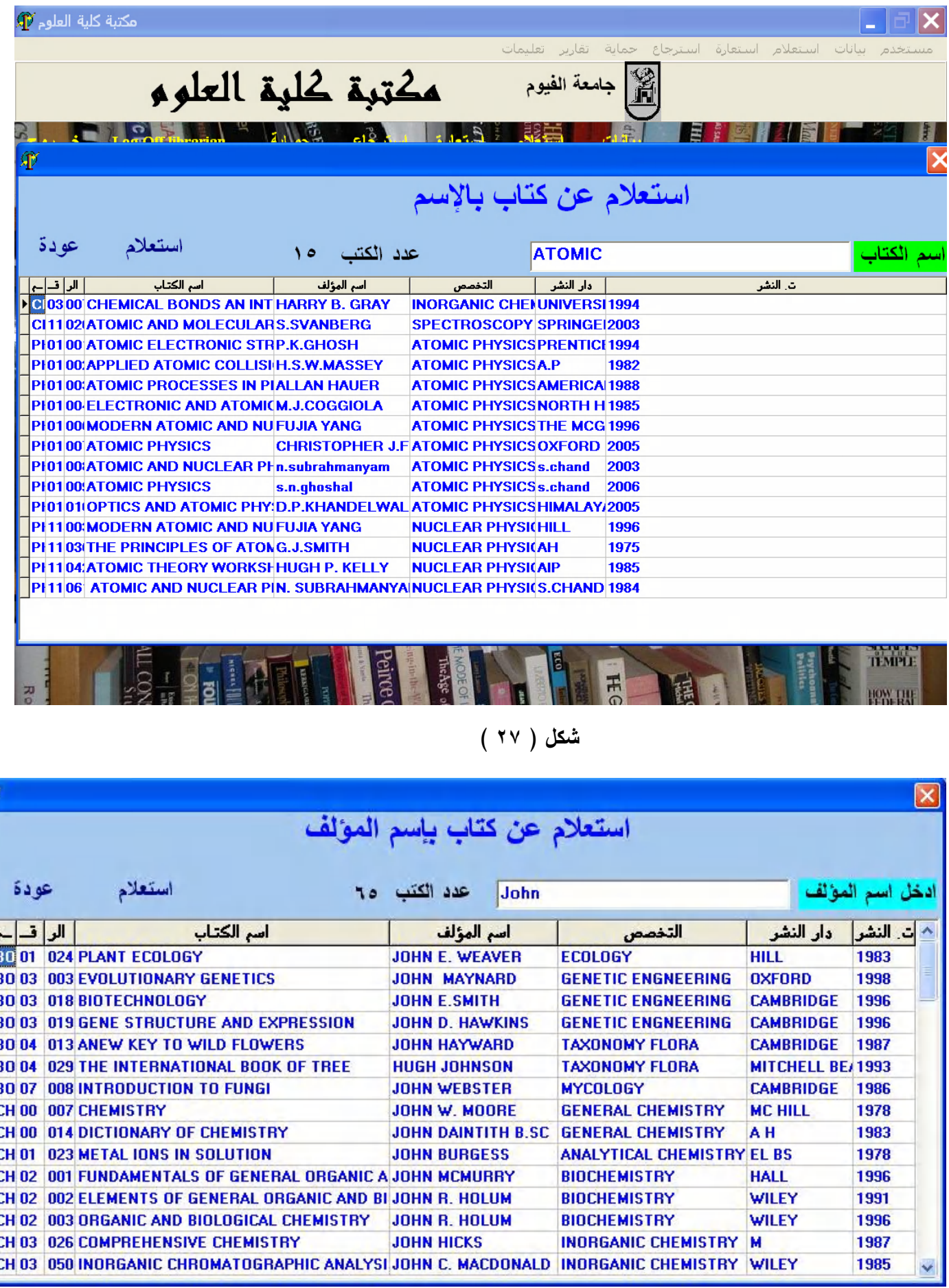

شكل ( ^ ) 


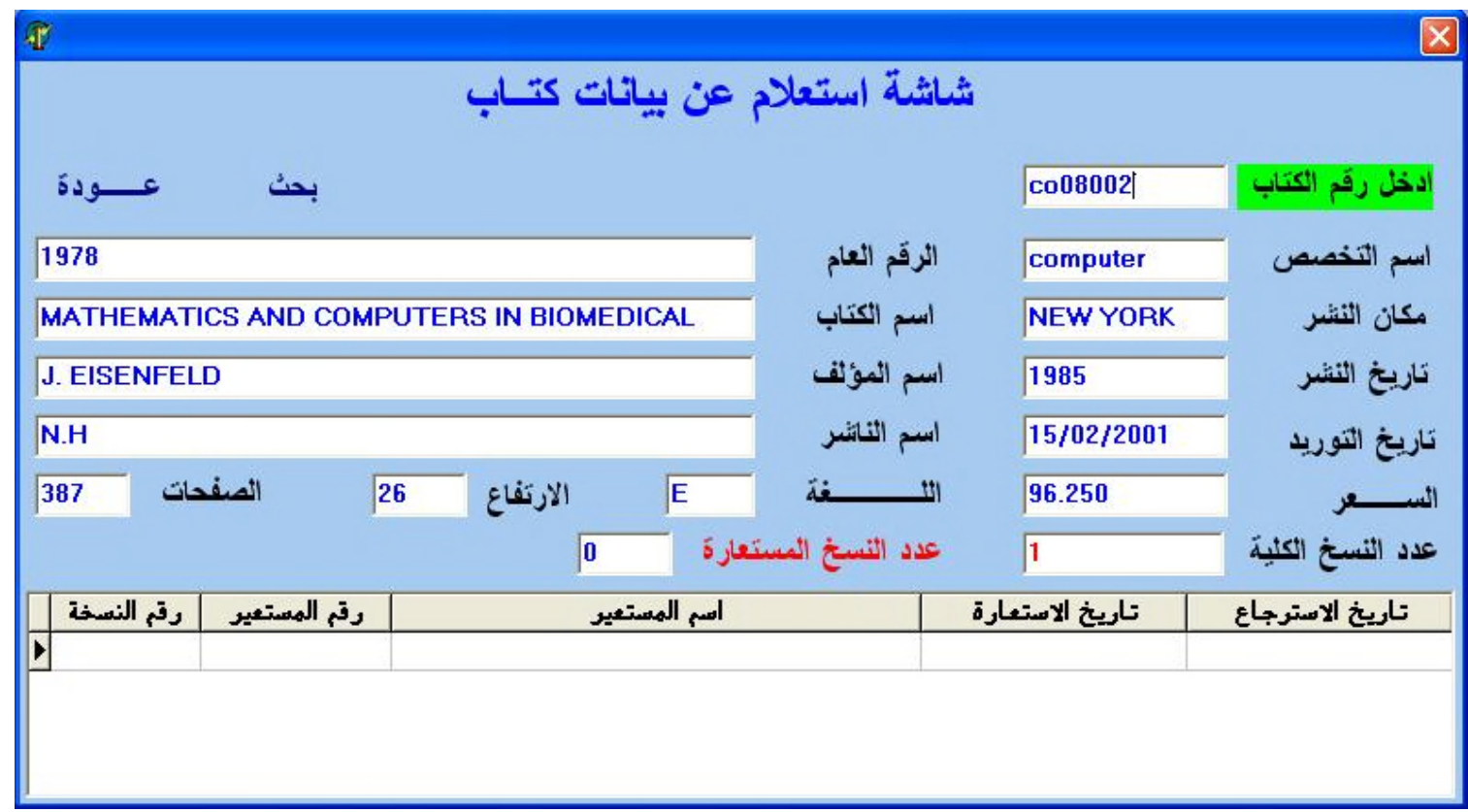

\section{شكل (rq)}

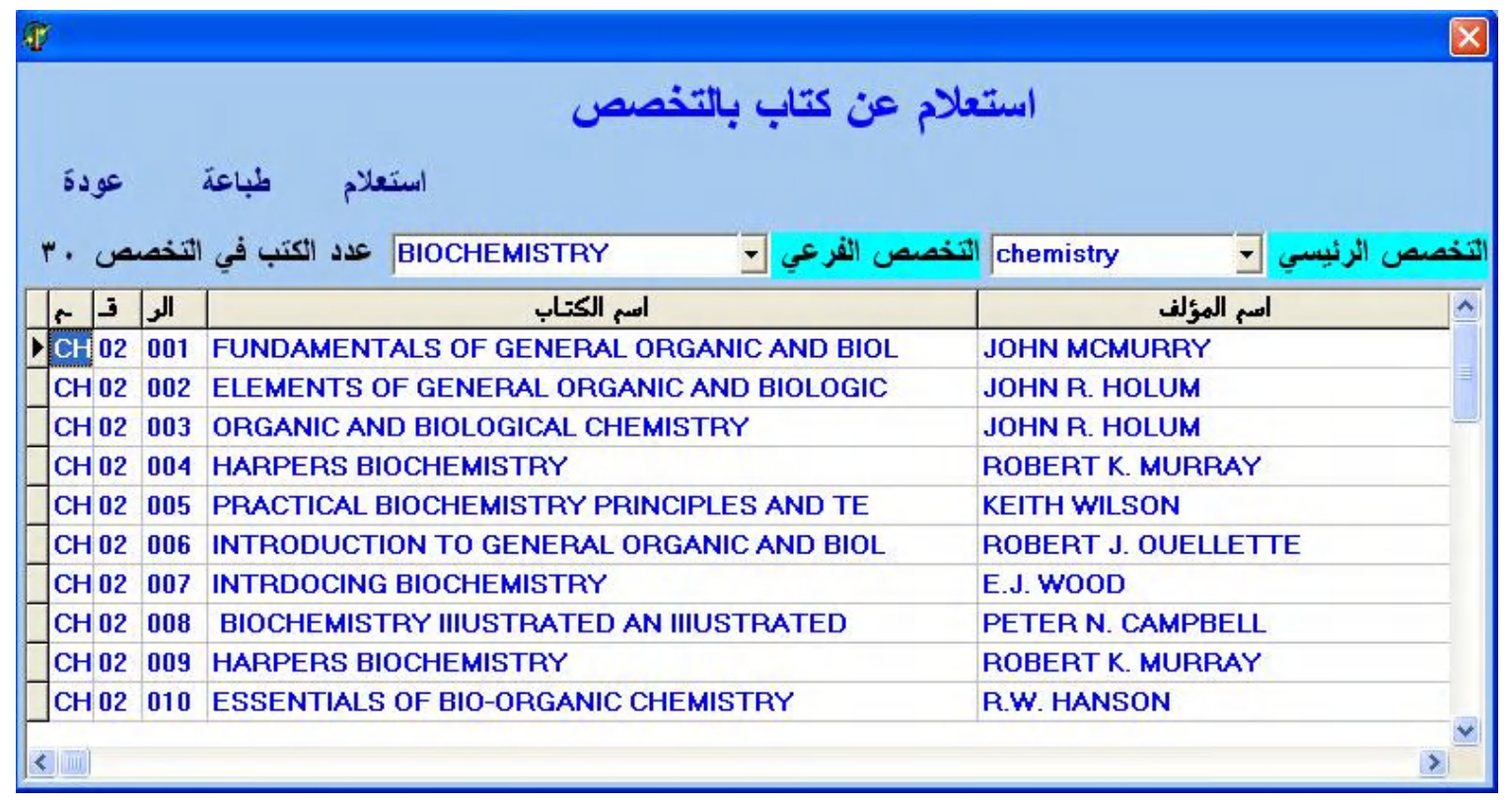

شكل (•) 


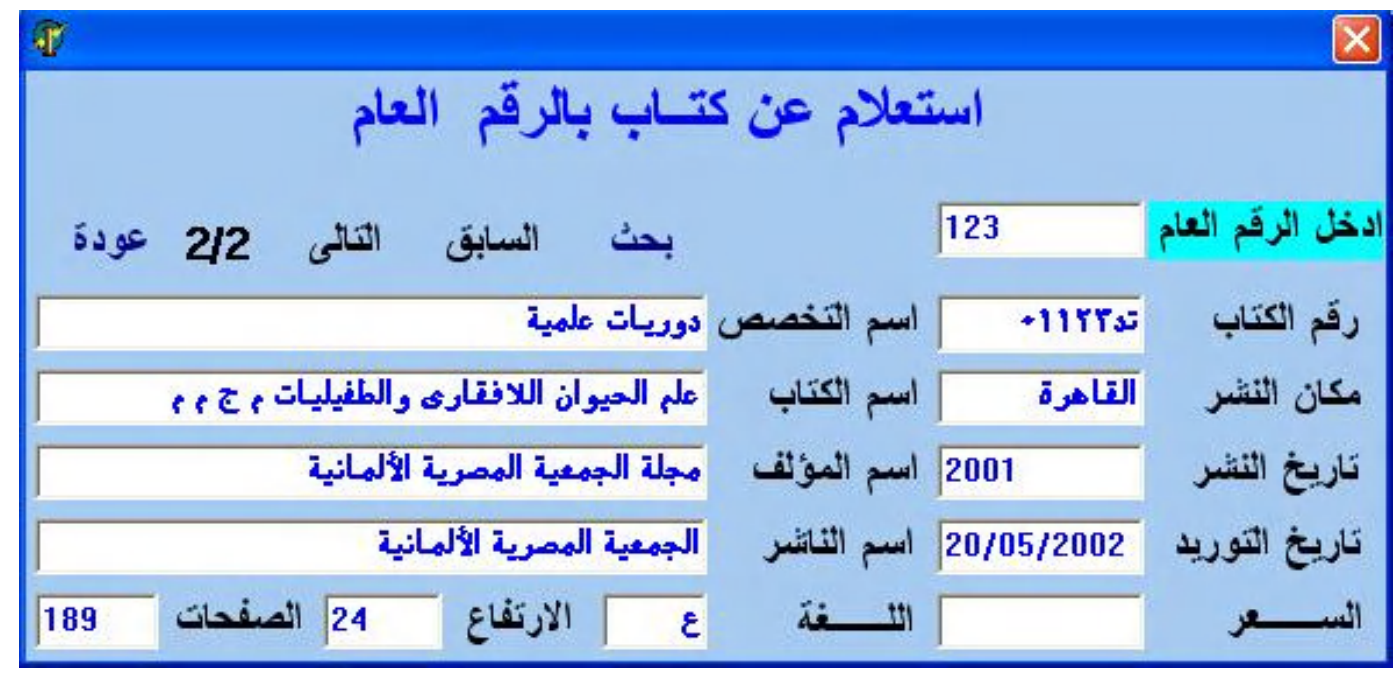

شكل (اי)

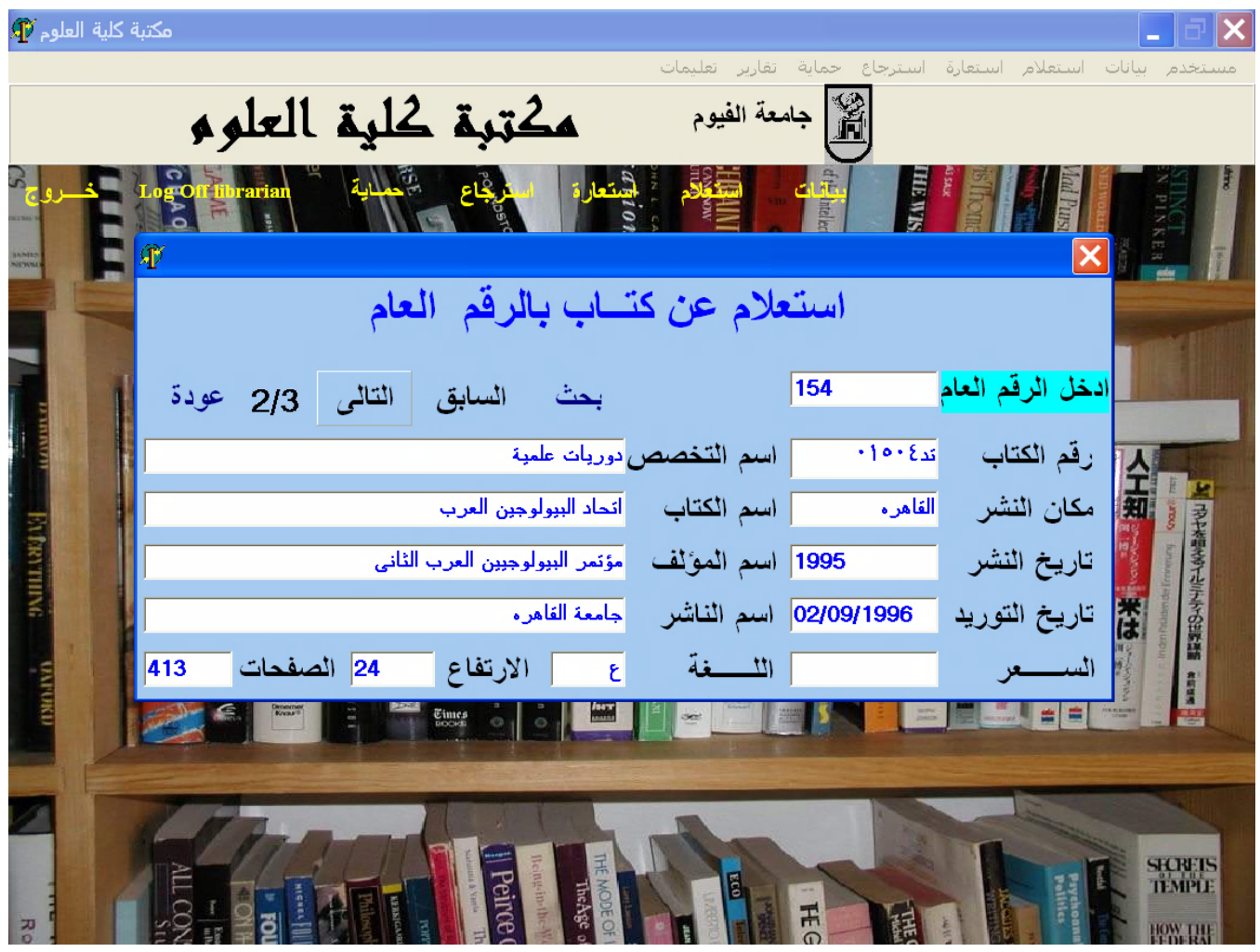

شكل ( r ) 


$$
\text { وأخر اجنبي ودورية ، ويظهر في هذا الثكل أن الرقم مسجل لثلاث كتب وهي هنا كتاب عربي الثكل مفتاح السابق والتالي الذي يظهر }
$$

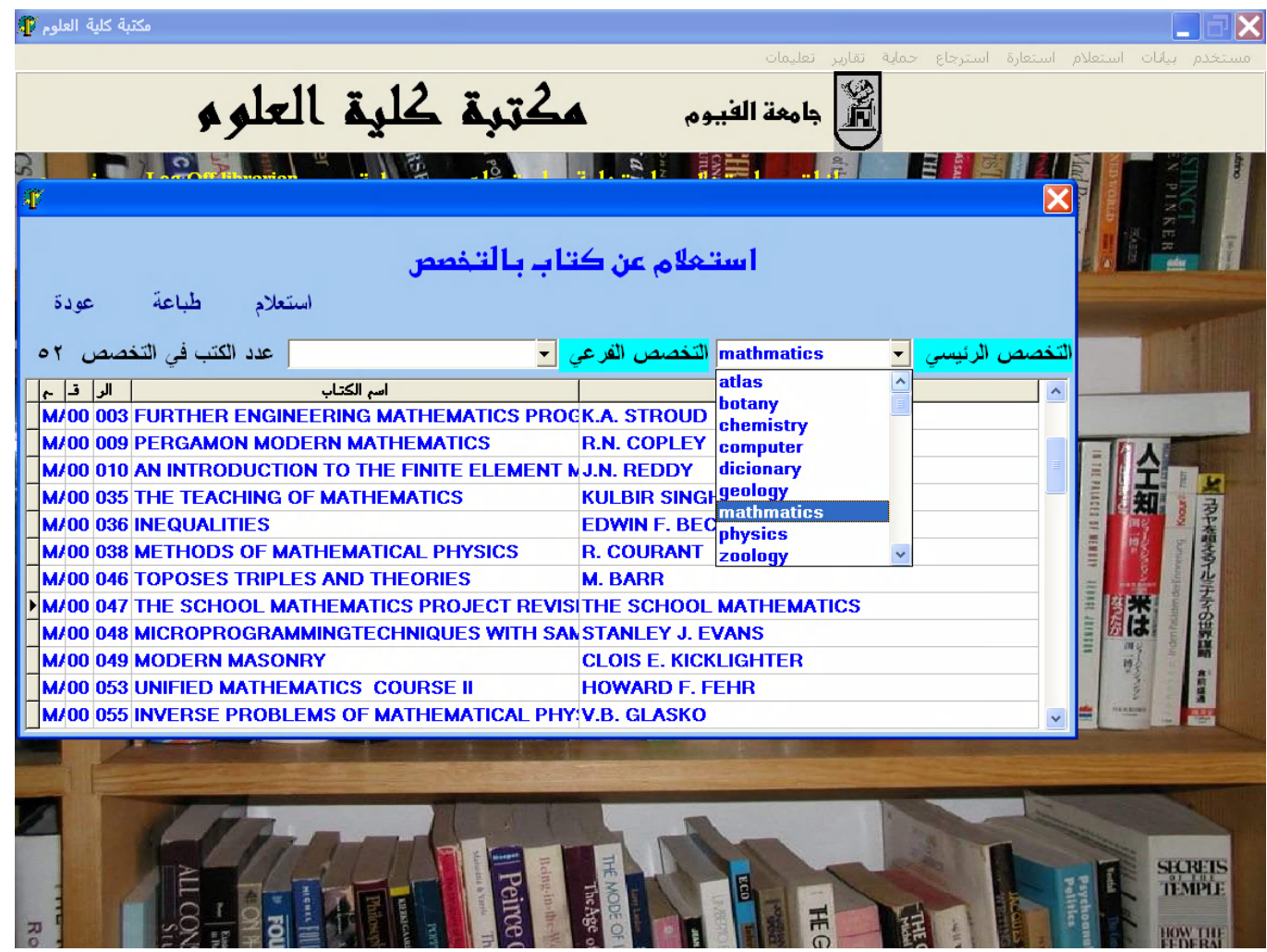

$$
\text { شكل ( rr ) }
$$




\section{تظهر هنا قائمة التخصص الرئيسي التى نختار منها .}

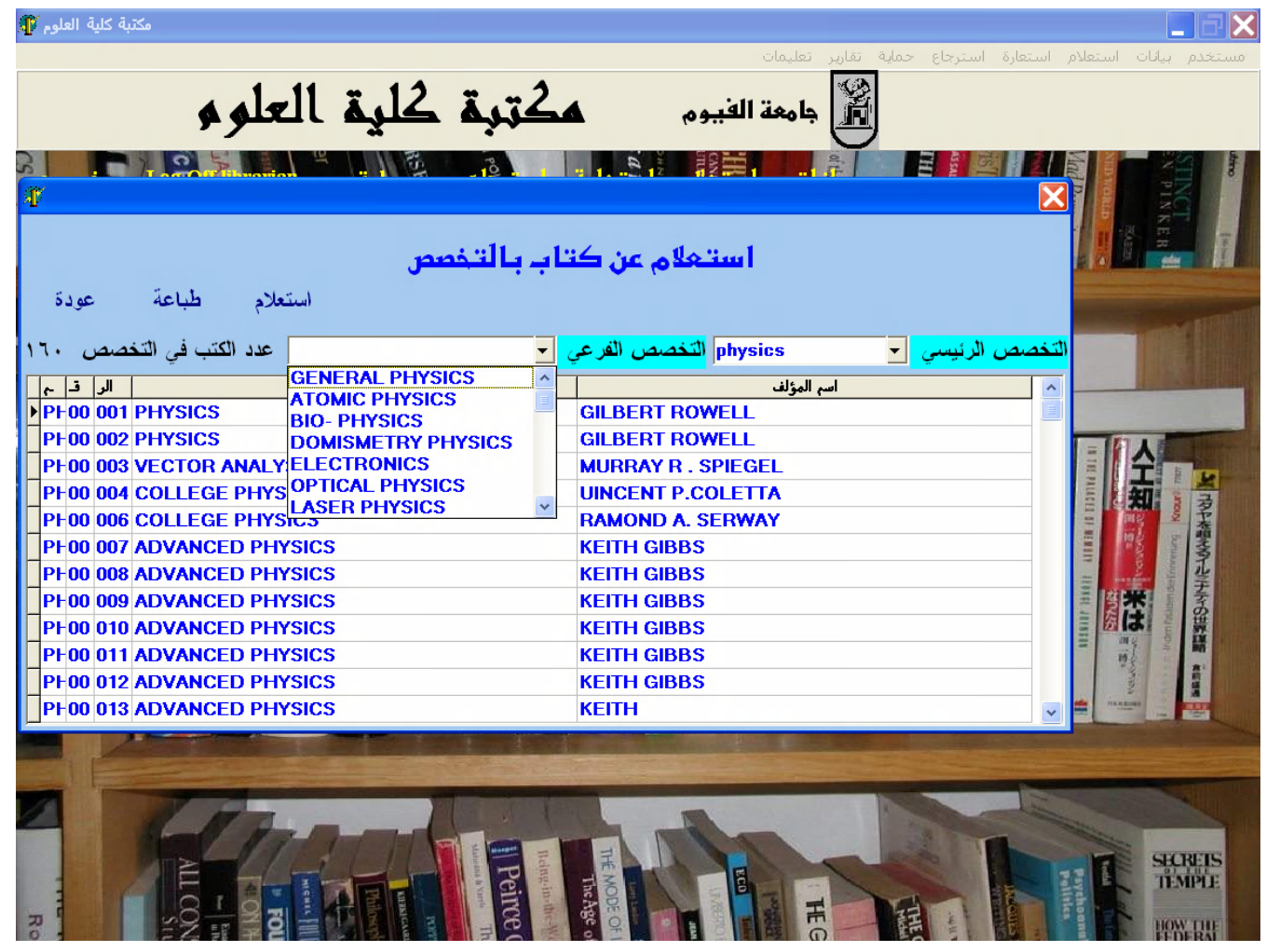

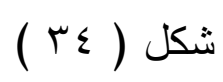


تظهر هنا قائمة التخصص الفرعي التى نختار منها .

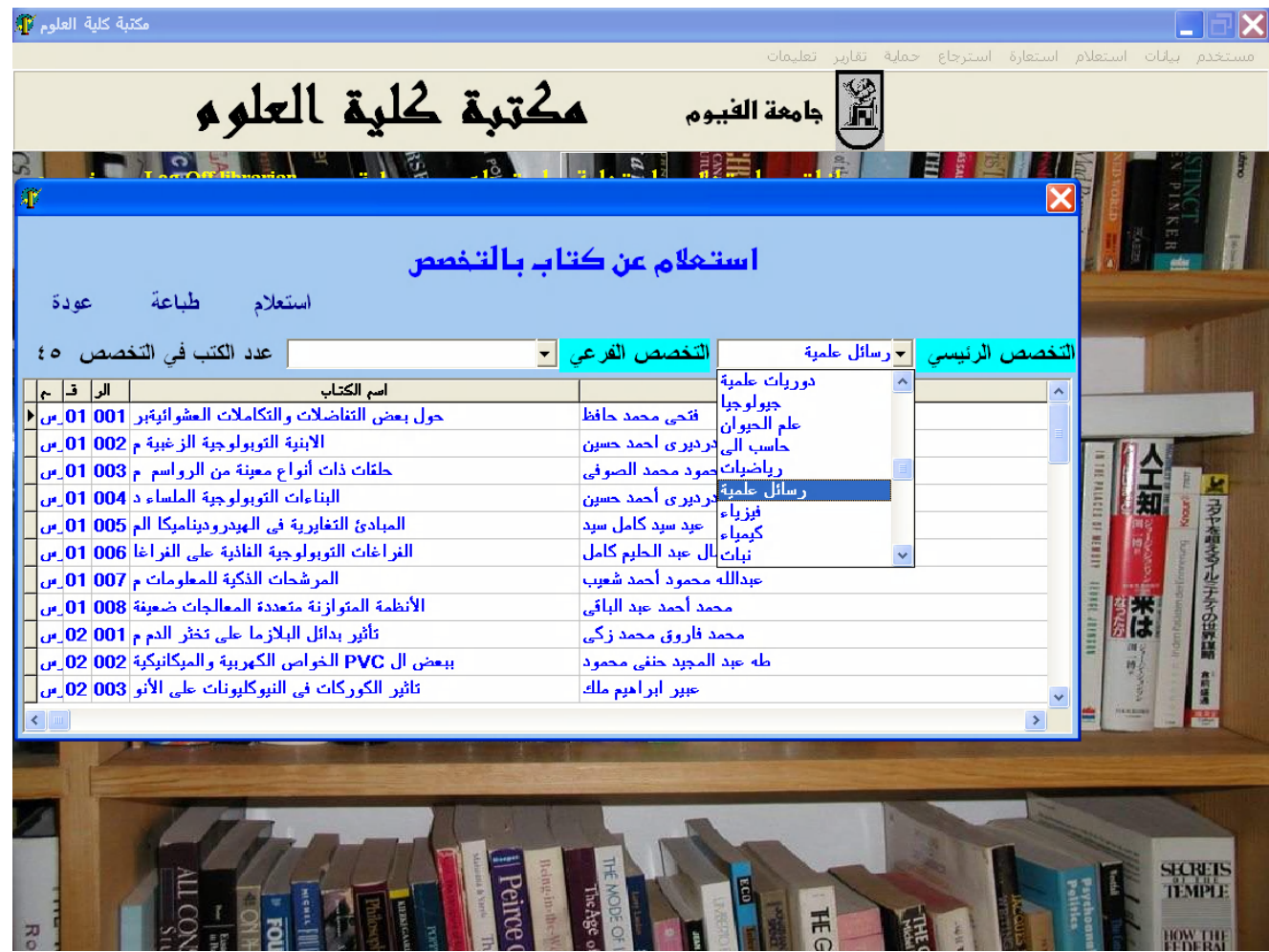

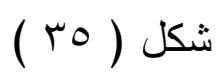

تظهر قائمة الرسائل العلمية حسب التخصص لأختيار ما نختار منه .

يتم عمل استعلام عن الكتب المستعارة ، وايضا التى انتهت فترة استعارتها ، وكذلك يمكن تحديد فترة والتعرف علي ما تم بها من استعارات كما فى الأثكال 


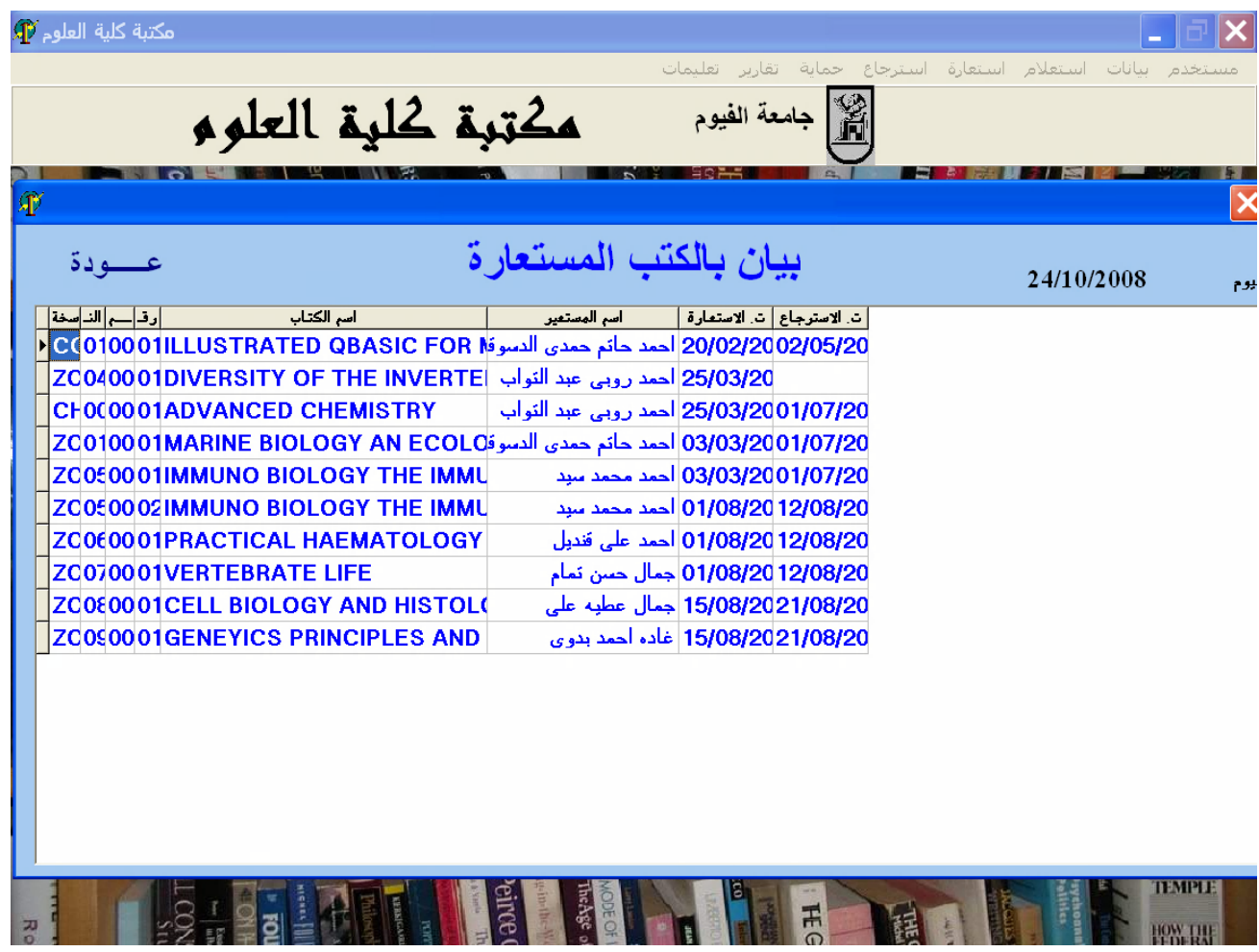

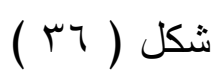




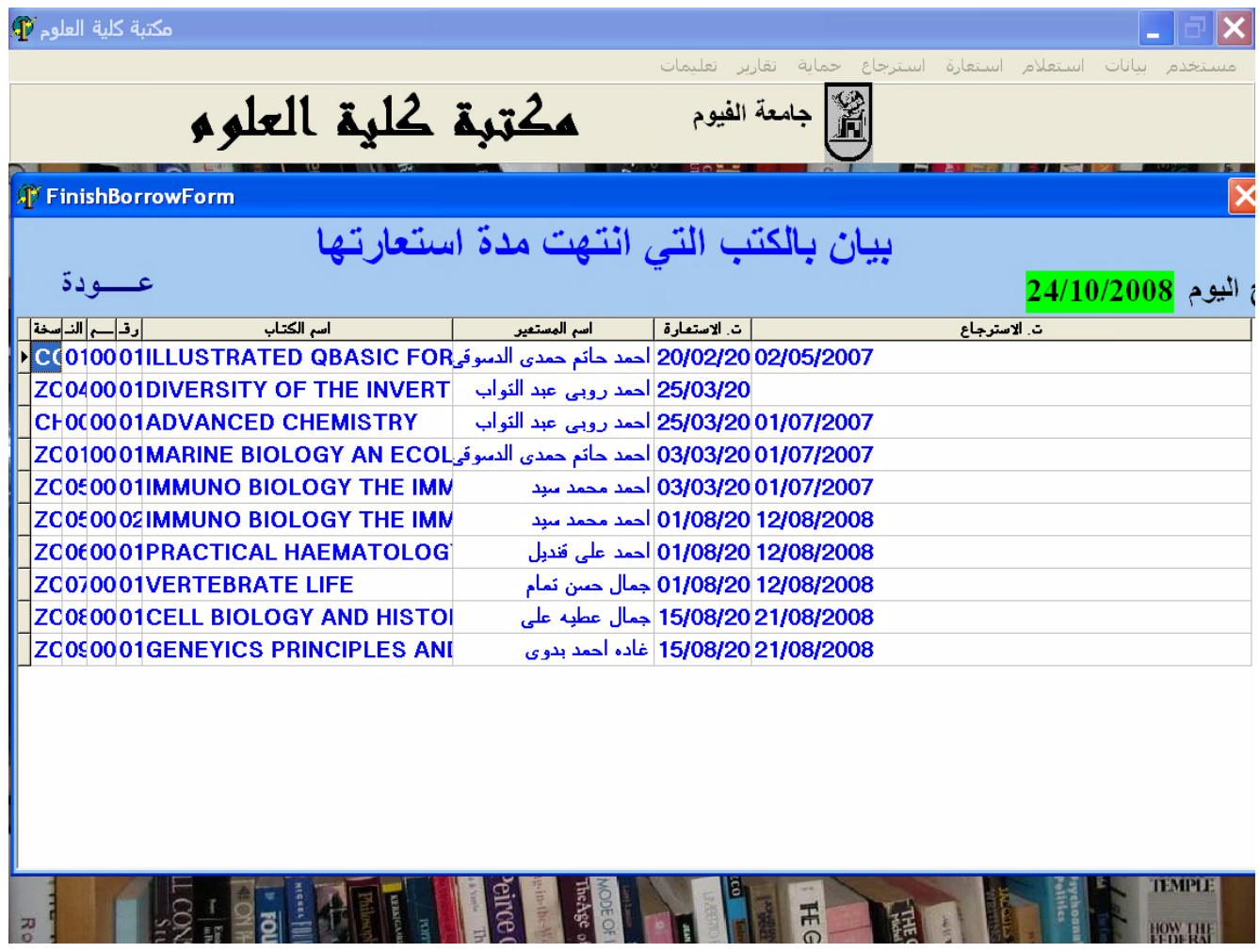

شكل ( ) 


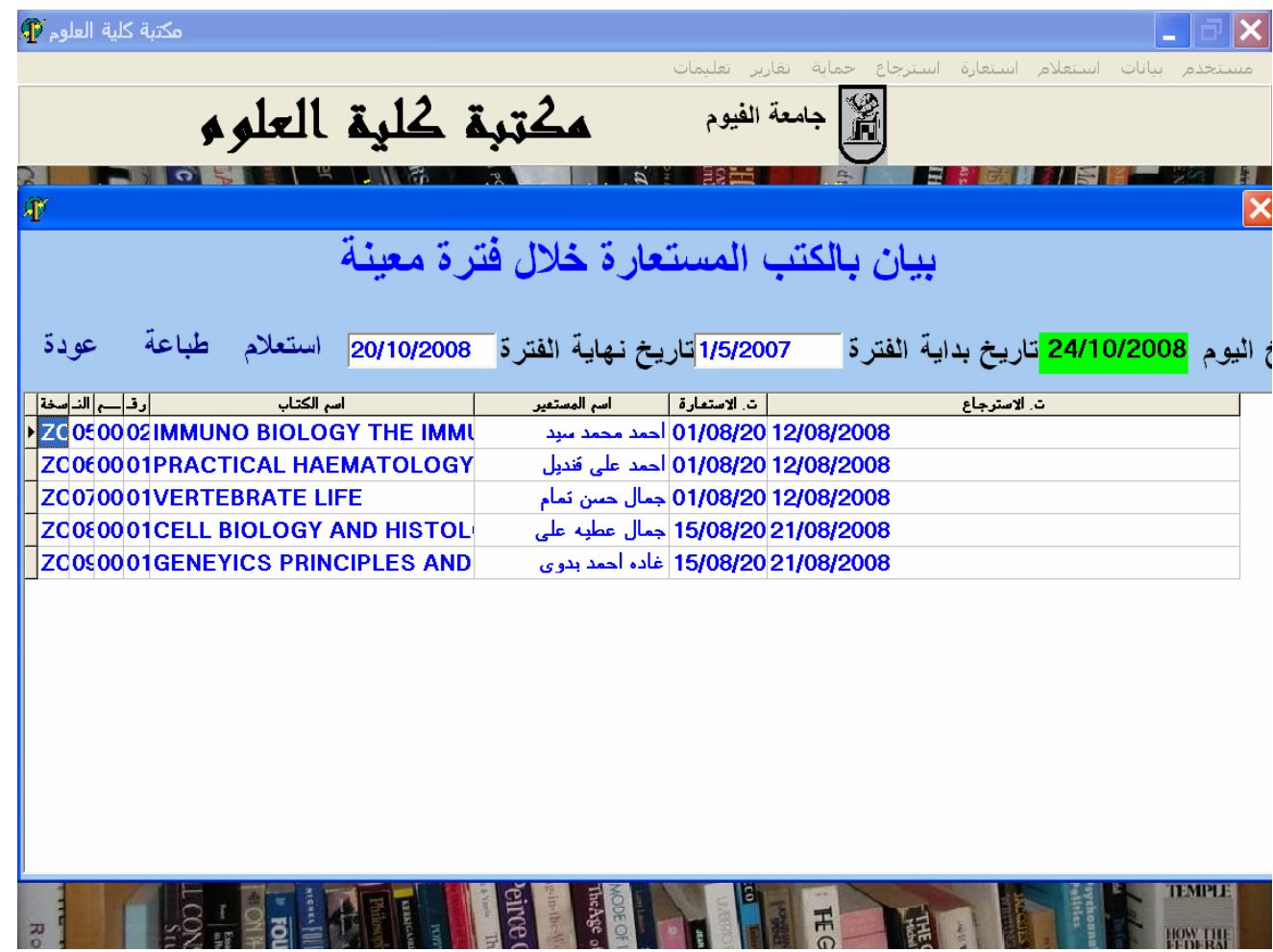

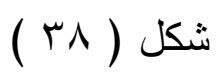

من خلال نموذج الاستعارة بمكننا عمل استعارة كتاب وذلك من خلال إضافة رقم الكتاب واختيار رقم المستعير ثم نسجيل تاريخ الاستعارة والنظام له أمكانية تحديد تاريخ الاسترجاع من خلا المدة التي نحدها للبرنامج (انظر

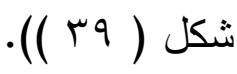




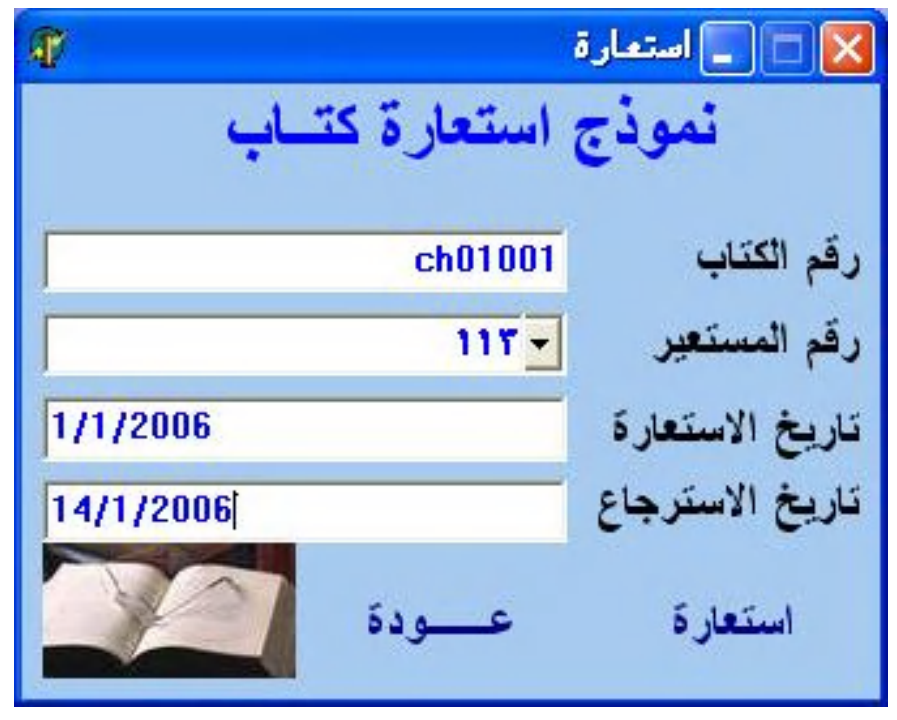

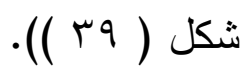

ويمكنتا هنا عمل بيان بالكتب المستعارة ، وأيضا معرفة الكتب التى انتهت فترةقأستعارتها ؛ وذلك من قائمة الأستعلام السابقة . (لايعا) الاسترجاع:

ويقوم النظام هنا بإمكانية استرجاع الكتاب من خلال نموذج استرجاع

كتاب ونسجل به رقم الكتاب فقط ونختار رقم المستعير ونحدد تاريخ الاسترجاع. 


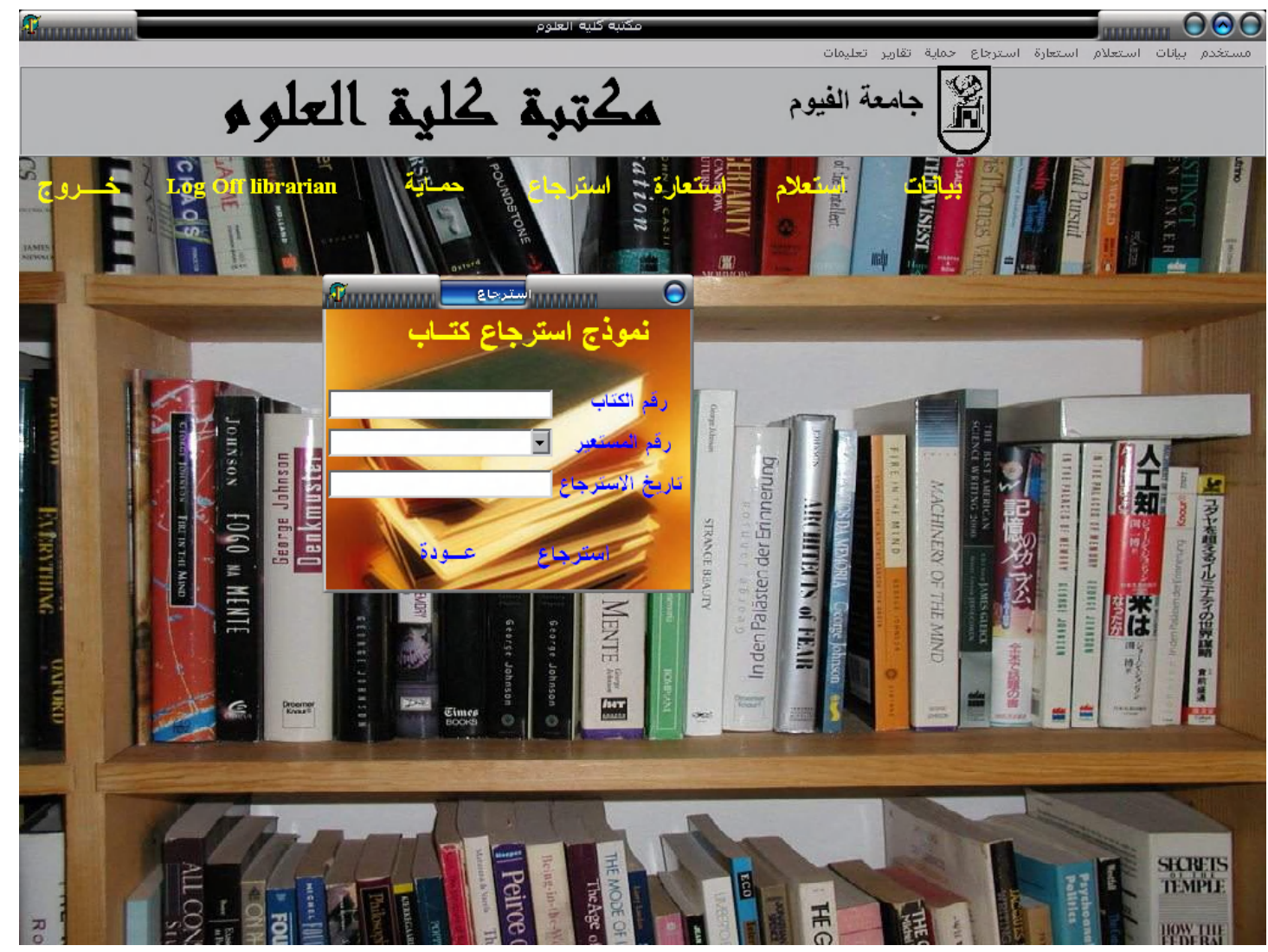

شكل ( • ( ) ( ) 


\section{(خامسا) حماية :}

تظهر هنا إحدى إمكانيات النظام الفريدة، حيث يمكن لمستخدم النظام

تحديد من له حق إضافة بيانات أو تعديلها أو حذفها ومن له حق الاستعلام فقط

عن بيانات وهنا يحدد النظام ثلاث مستويات للحماية (انظر شكل (1)).

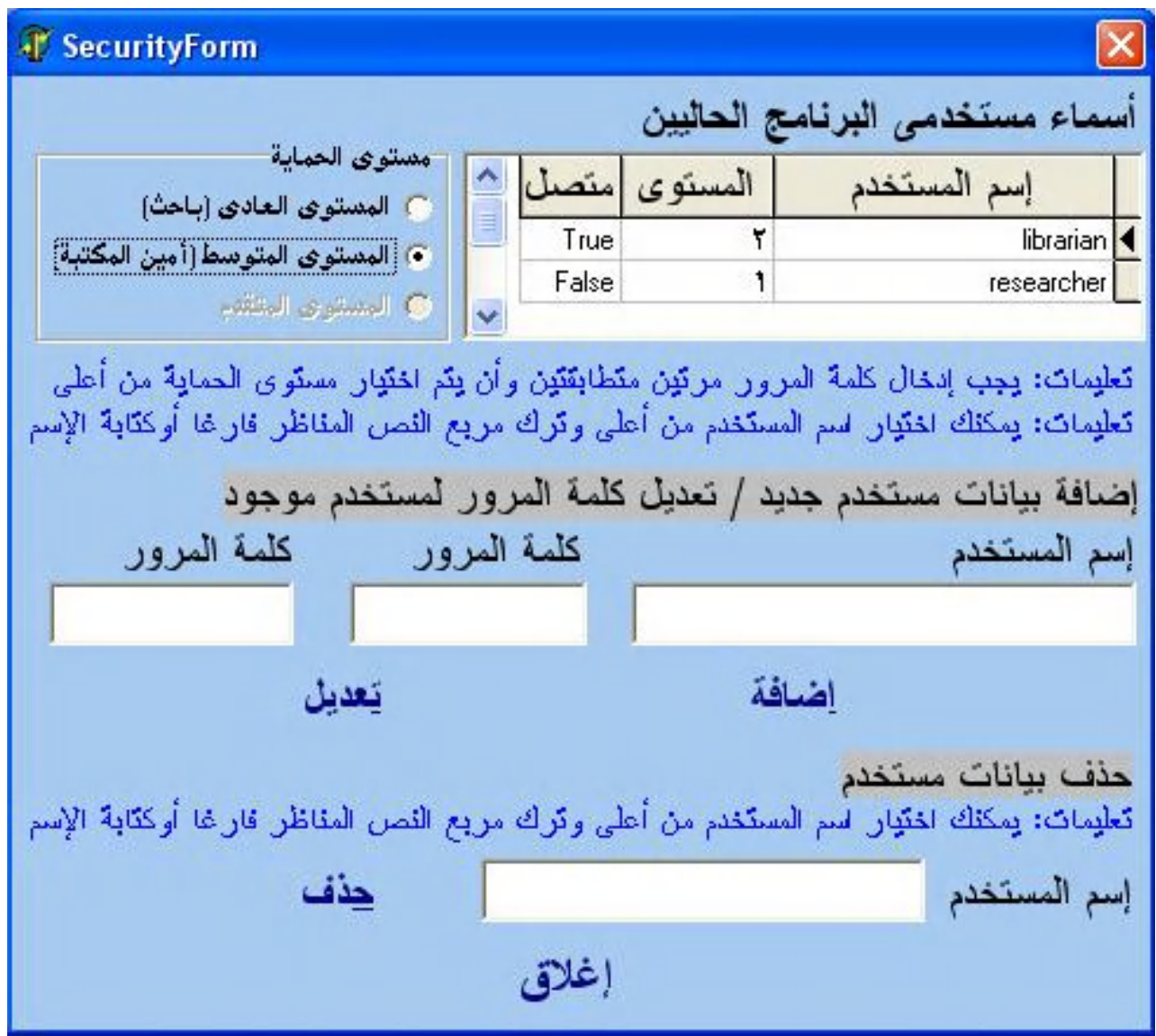

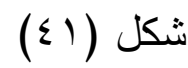

$\varepsilon$ 


\section{(سادسا) خروج مؤقت :}

وهو نظام حماية، من خلال هذا الاختيار يمكننا الخروج من البرنامج ثم الدخول

$$
\text { إليه مرة أخرى بإسم جديد . }
$$

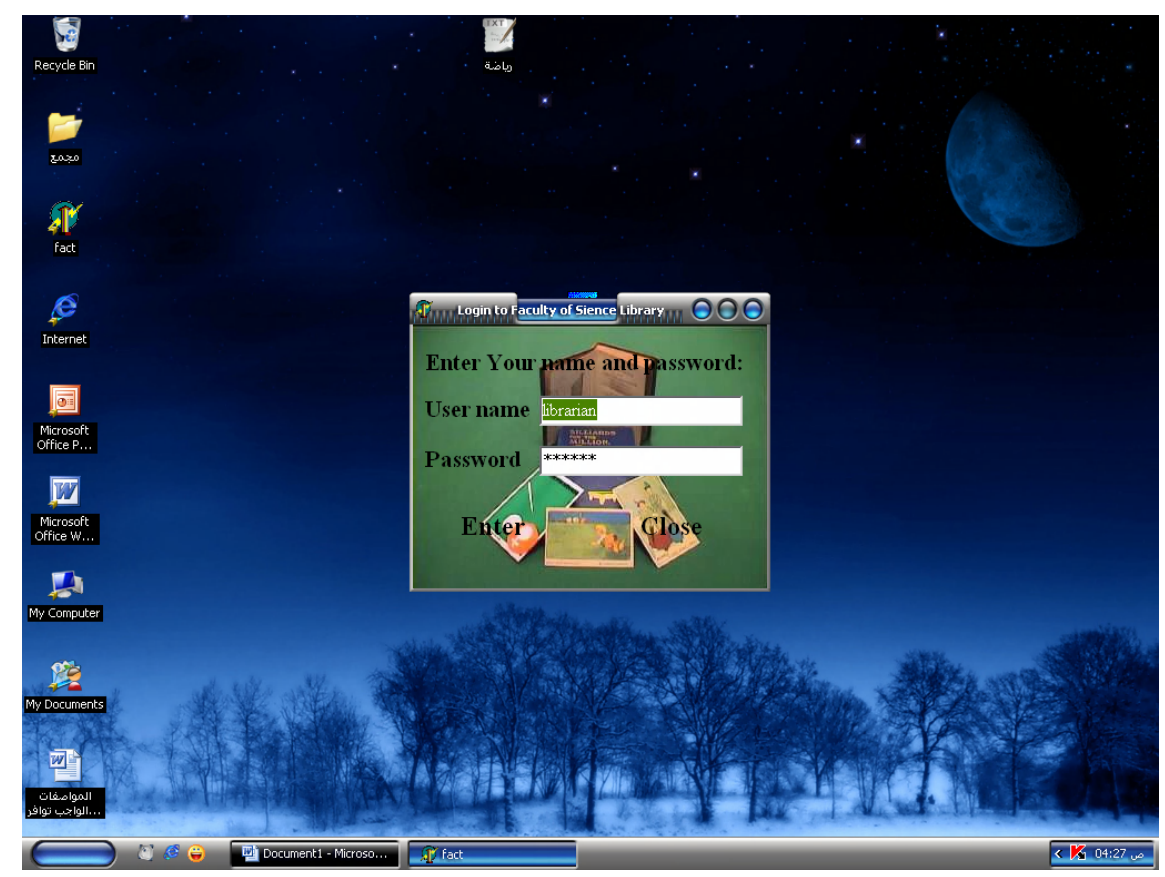

شكل ( ) 


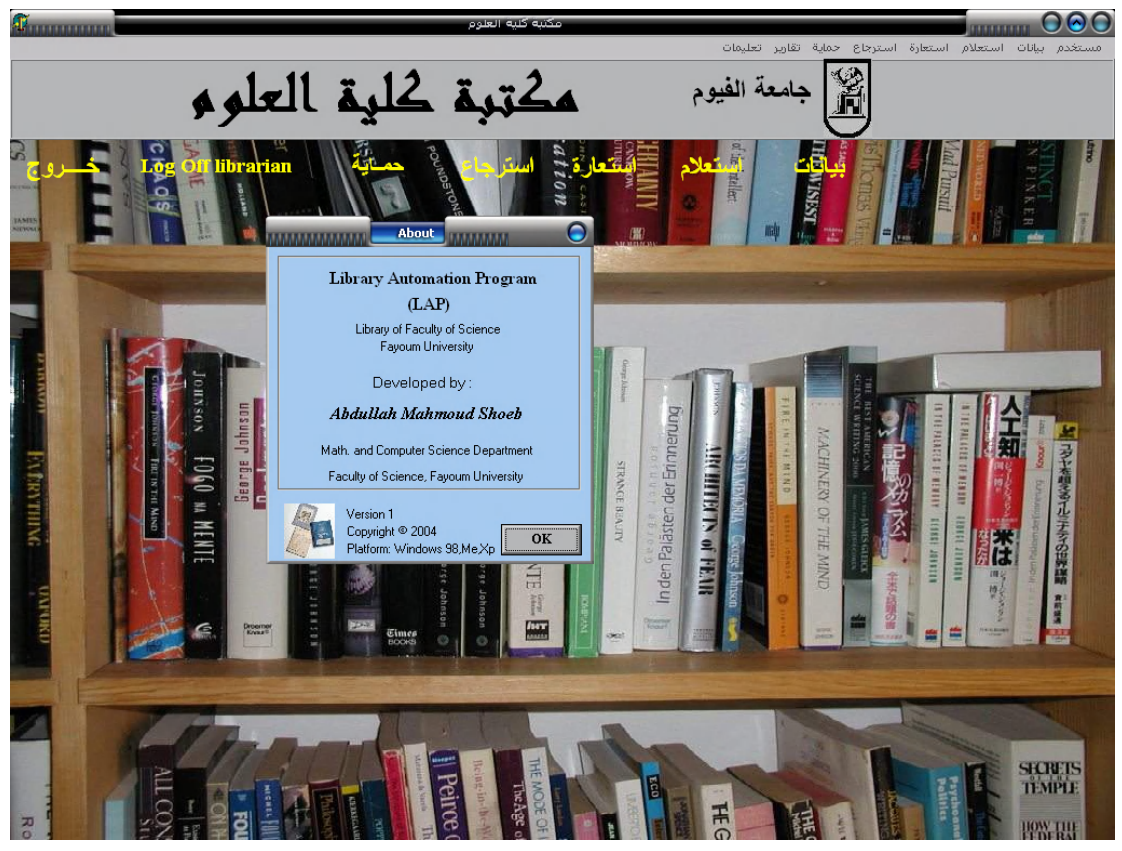

$$
\begin{aligned}
& \text { شكل ( ) ( ) } \\
& \text { وهو يوضح تعليمات لتشغيل البرنامج والتعرف علي البرنامج وعلي } \\
& \text { مصممة . } \\
& \text { - النظام يعمل بطريقة القوائم المنسدلة بالأضافة الى ظهور الثاشات } \\
& \text { الموضحة للنظام : }
\end{aligned}
$$

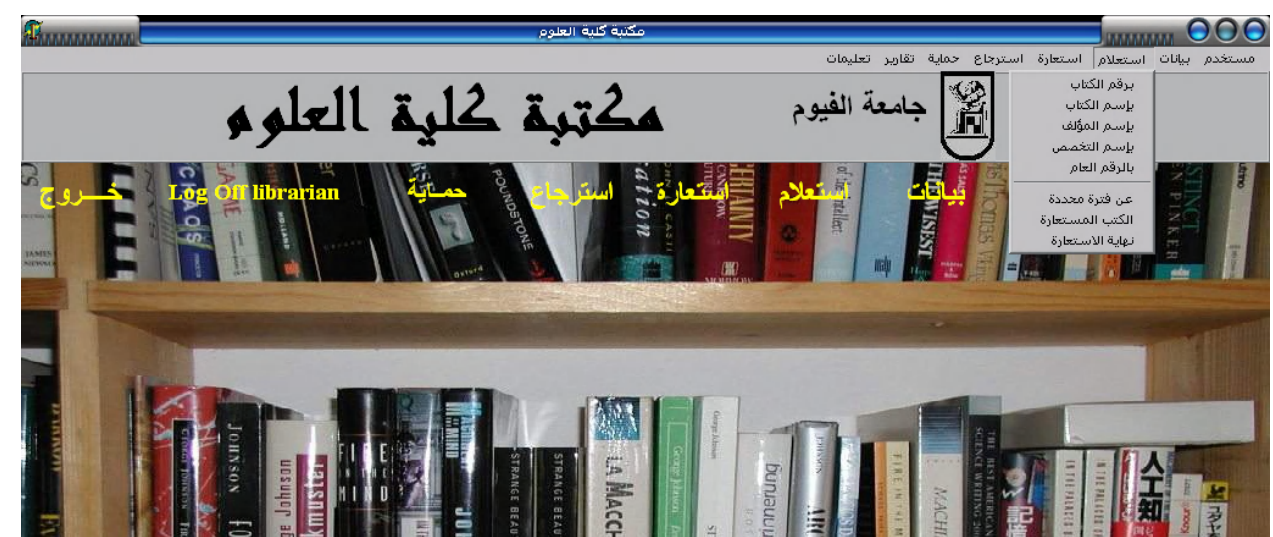




\section{شكل (}

\section{(سابعاُ) التقاريــ}

يستطيع البرنامج أن يعطي العديد من التقارير منل : -

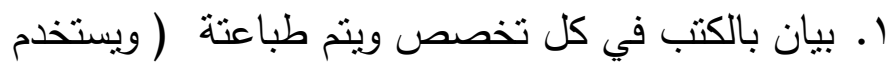

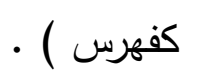

r. بيان بجميع الكتب المستعارة .

r. بيان بالكتب المستعارة خلال فتزرة محددة .

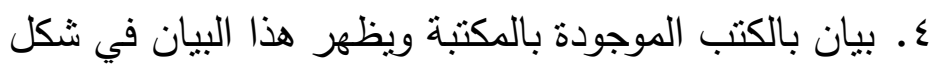

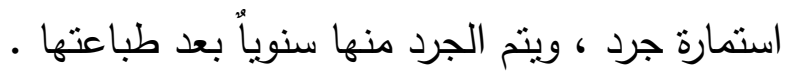




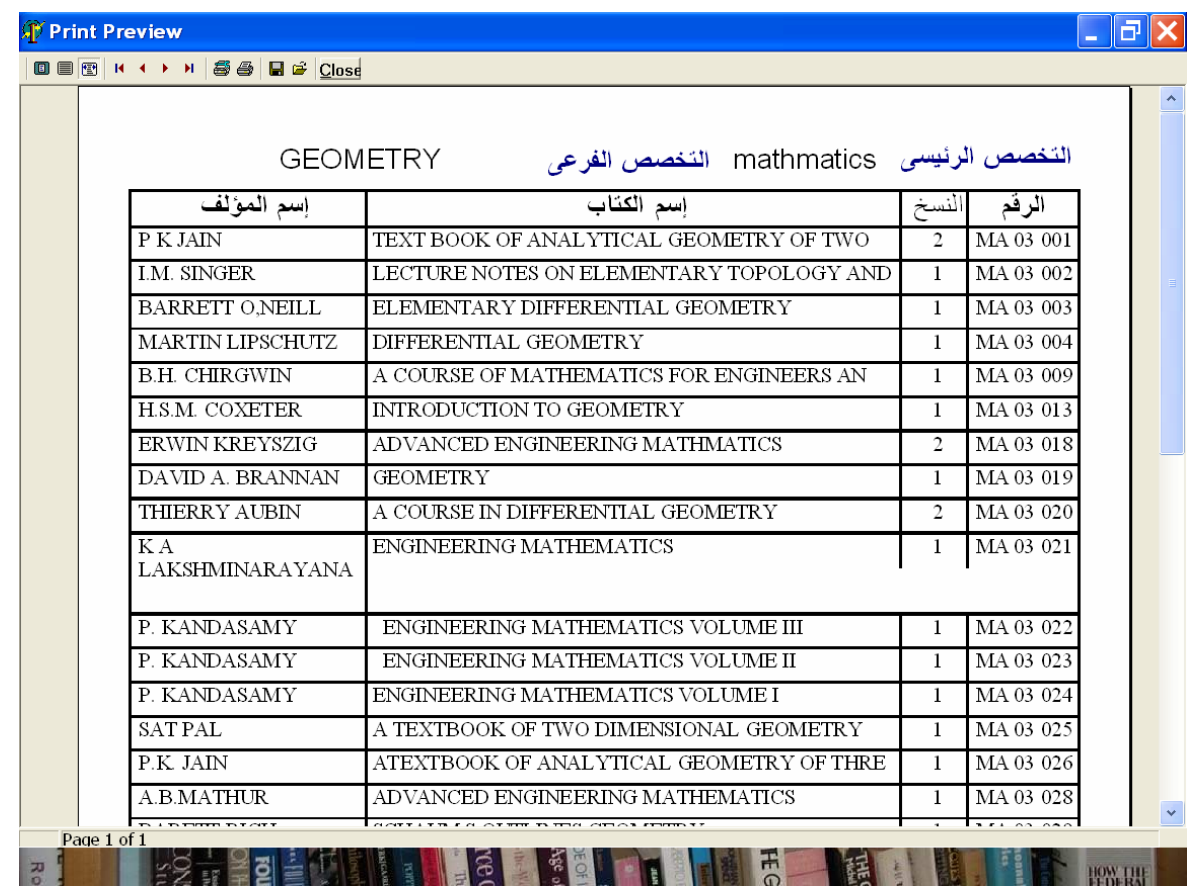

\section{شكل ( 0؛ )}




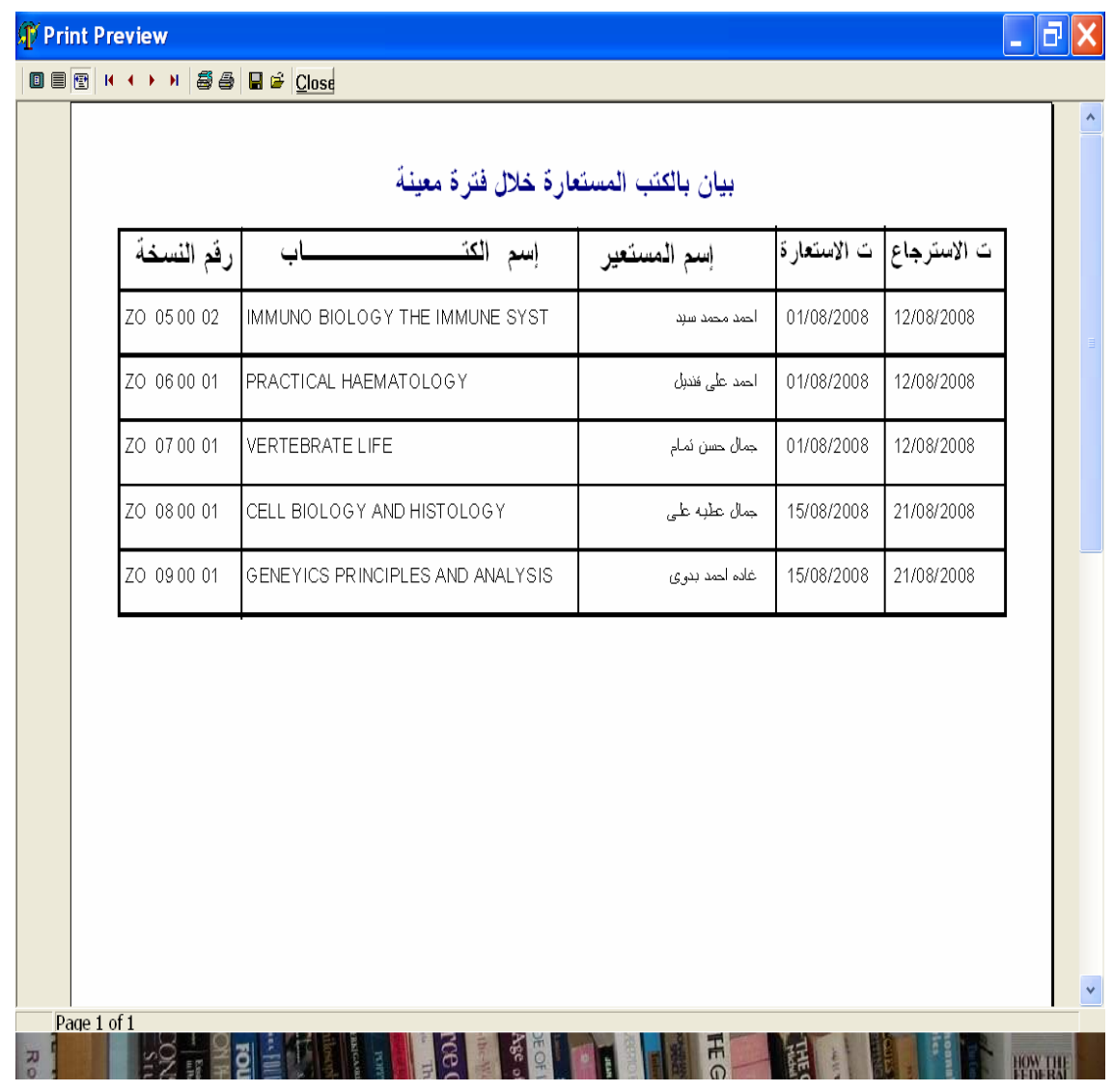

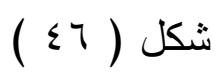




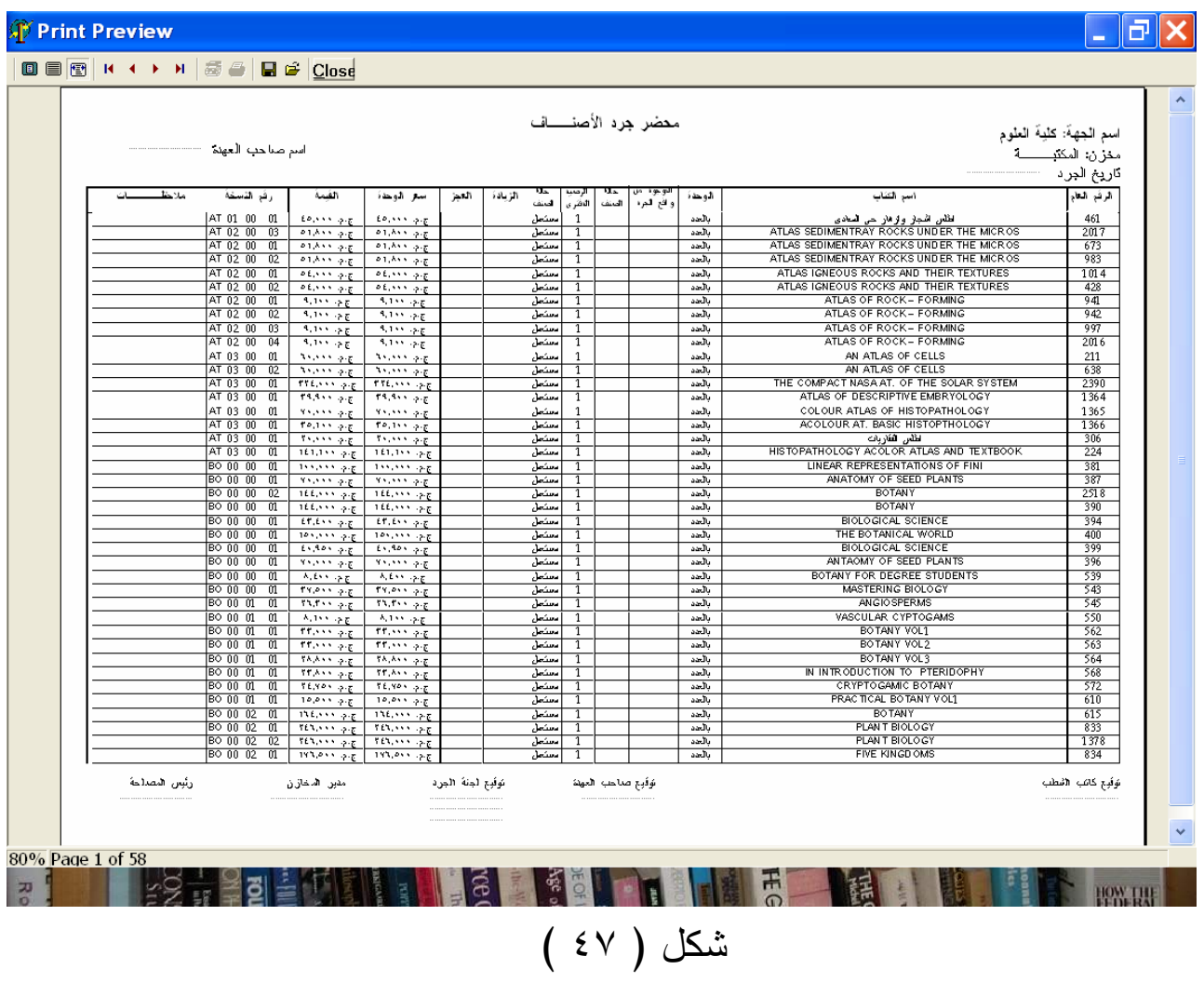

هذا البرنامج كان بعمل بكفأة عالية الى وقت قربب بمكتبة كلية العلوم - جامعة الفيوم ومكتبة كلية الحاسبات والمعلومات - جامعة الفيوم ؛ ولكن هناك أختلافين جـوهربين بـين النسختين الموجـودين بـالمكتبتين ، ففي مكتبـة كليـة الحاسبات والمعلومات نجد زيادة طفيفة في نسخة البرنامج الموجود لديهم ؛ حيث هنـاك أمكانيـة أضـافة محتويـات الكتاب وذلك بتصوير صفحة المحتويـات عن طريق الماسح الضوئي وهناك أختلاف آخر حيث يتم أضافة حقل ISBN عند تسجيل الكتاب وهذه النسخة معدلة حديثا بمعرفة مدير المكتبة والسادة اعضاء هيئة التدريس بكلية الحاسبات والمعلومات . 


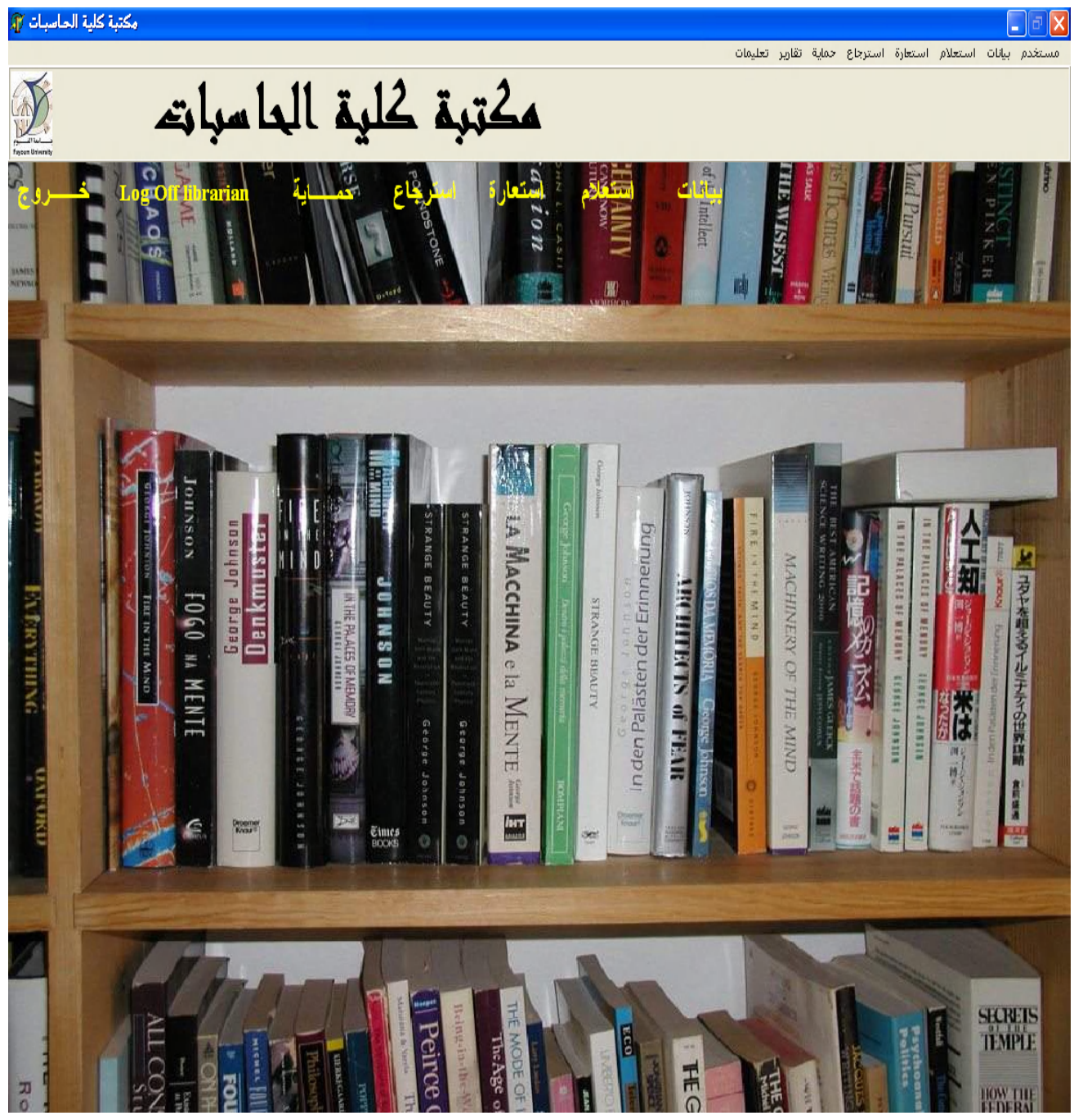

شكل ( ) ) 


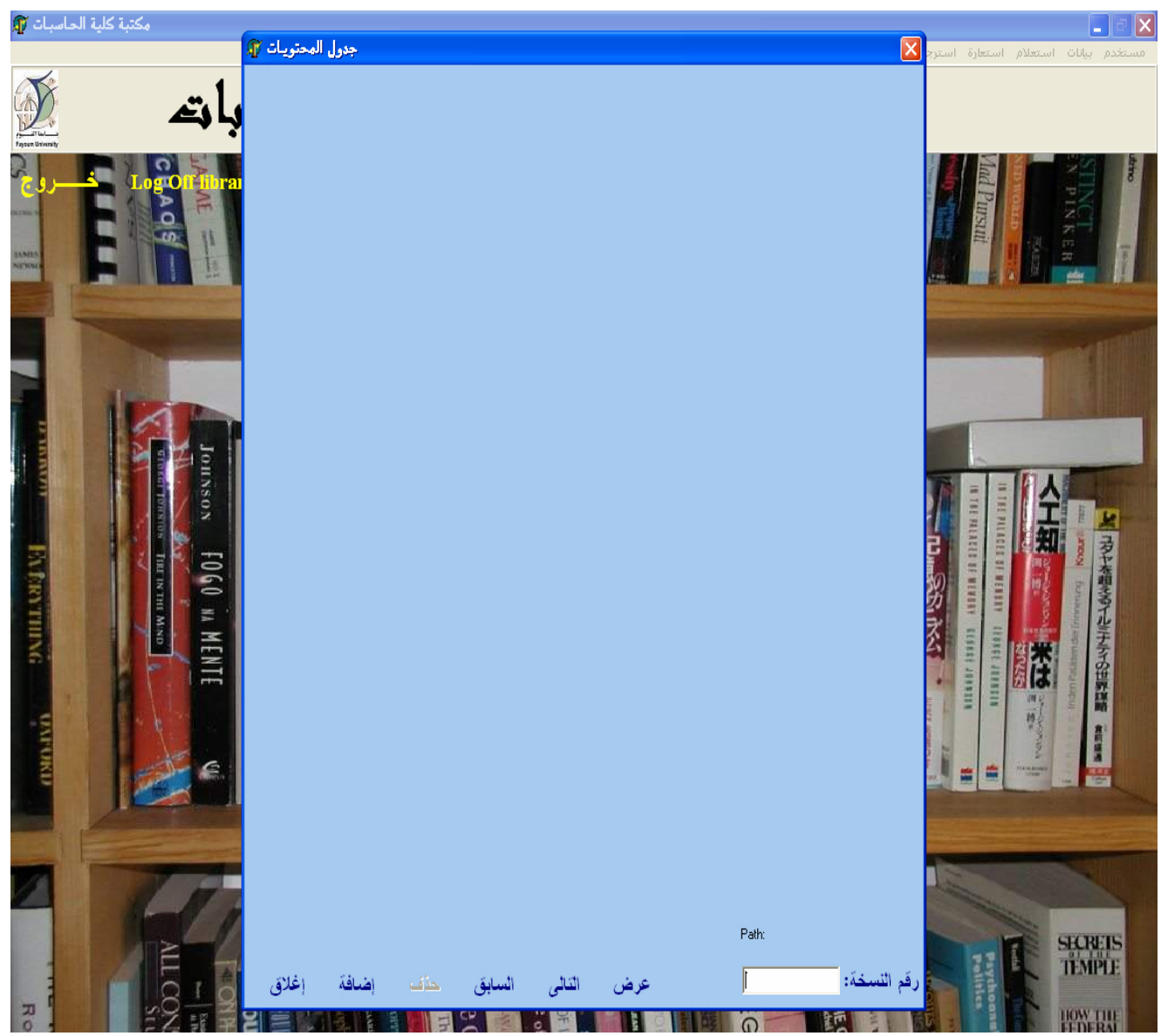

\author{
شكل ( 19 ) ) \\ هنا الصفحة التي يتم بها تصوير محتويات الكتاب وعرضة .
}




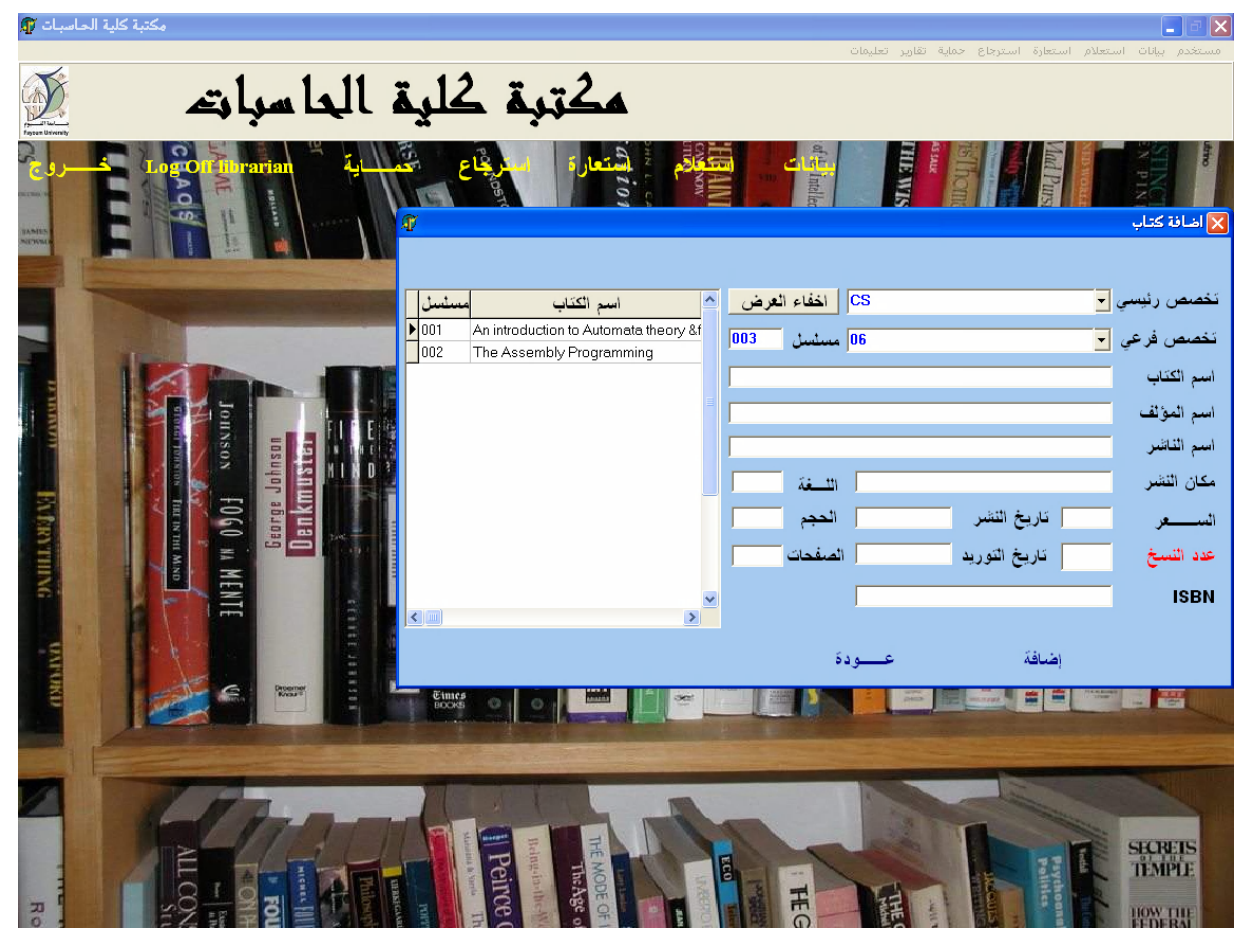

$$
\text { شكل ( ) }
$$

يظهر حقل ISBN ضمن حقول بطاقة الكتاب .

ونستطيع من خلال دراسة هذا البرنامج والعمل من خلالة التعرف علي اوجة القوة

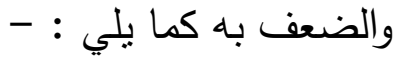

\section{- أولا ) معيزلت البرنامجج}

$$
\text { ا ـ سهولة استخدام القوائم المنسدلة والتقريعات الموجودة بها . }
$$

r. سهولة الأضافة داخل البطاقات وعدم وجود تفربعات بداخل البطاقه كما

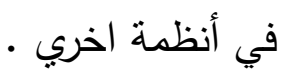

r. سهولة التعديل في الأضافات الموجودة بالبرنامج سواء اضافة ( الكتب

$$
\text { ع. سهولة عملية الحذصفات ، المستعيرين ) . }
$$

0. ظهور رسـائل تأكيديـه ، لتأكيـ أجـراء عمليـه الأضـافة ، التعـديل ، او

$$
\text { الحذف. }
$$


T. الأمسن والسرية التي يتصف بها البرنـامج في عمليه الدخول وأعطساء

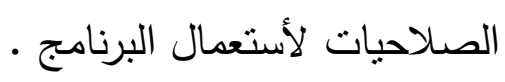

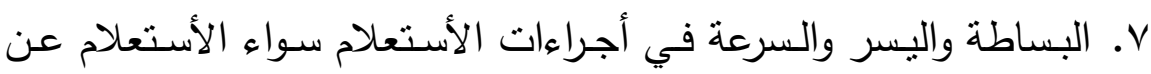
كتاب ، مؤلف ، تخصص أو عن الأستعارة .

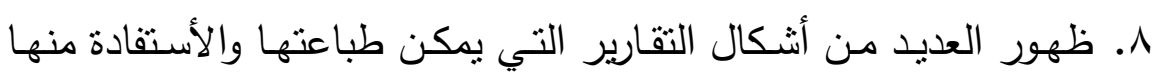
لعمل الأحصائيات ، او الفهارس الورقية او الجرد السنوي •

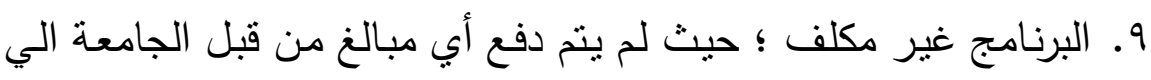

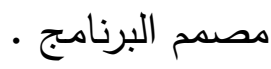
• 1 - يمكن أجراء التعديل والتحديث في البرنامج ببساطة ويسر .

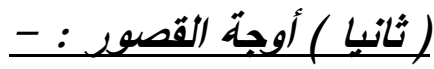

I. عدم أتاحتة من خلا الإنترنت .

r. التفرد في التصميم لشخص واحد عند وجود مشكلة

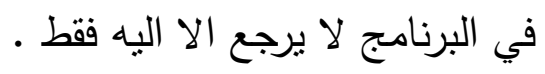

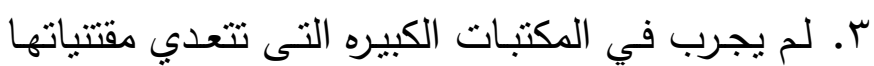

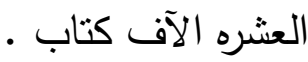

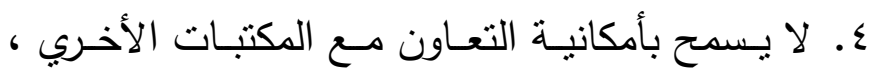

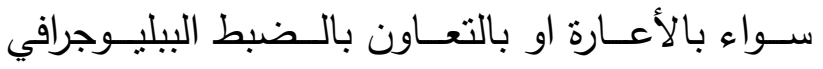

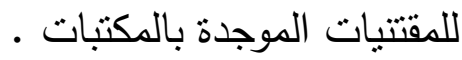
ه. مشكلأت قواعد البيانات المعتاد ، كأن يفقد أمر أو باله

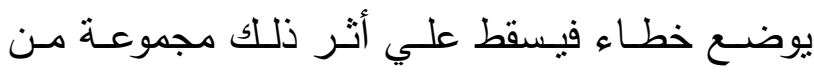

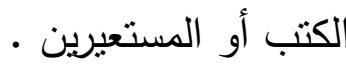

\section{نظام المستقبل لمكتبات جامعة الفيوم:} يسعى اتحاد المكتبات الجامعية المصرية بالتعاون مـع مركز تقنتيه المعلومات المعات و الاتصالات بجامعة المنصورة الى تطوير نظام المستقبل لميكنة اجراءات التهات العمل 
فى المكتبات و مراكز المعلومات بحيث يتوافق مع المتطلبات و المعايير العالمية للانظمة الالية فى المكتبات و مؤسسات المعلومات المات

\section{ميكنة مكتبات الجامعات المصرية}

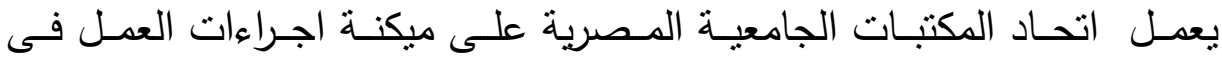

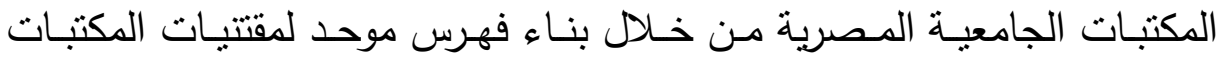

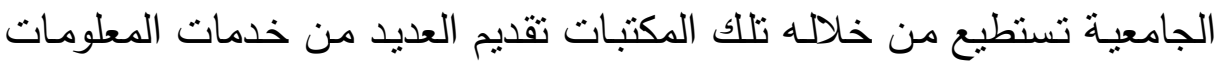

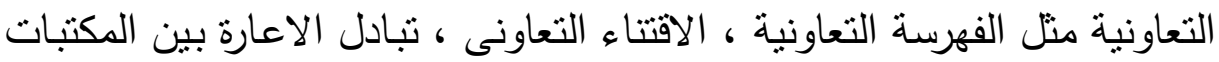

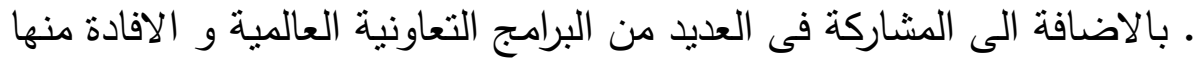

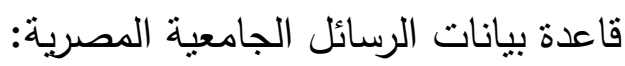

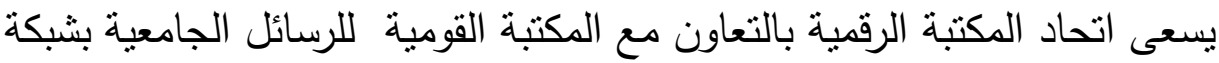

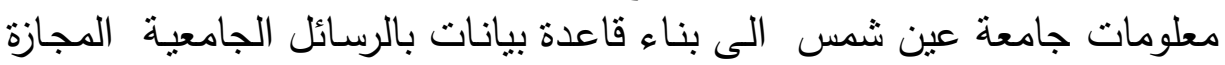

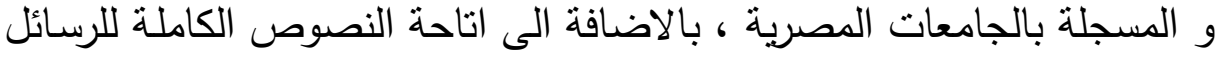

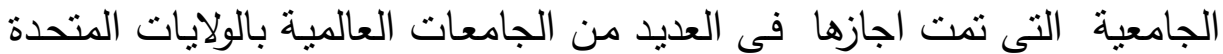

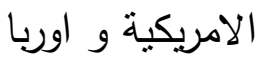
المكونات الرئيسية للنظام :- الائا

(الفهرسة - ضبط الدوريات - القوائم الاستتادية - الاستعارة - الجرد - صيانة

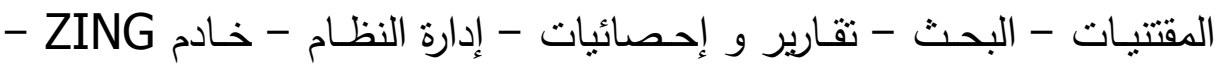

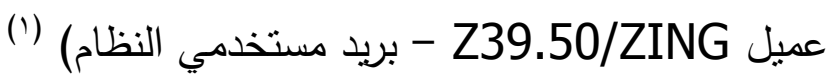

$$
\text { أ - أفهرسة - 20 - n }
$$

• • النظام يدعم معيار مارك (ب في فهرسة الأوعية

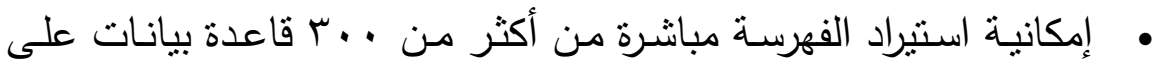
مستوي العالم مجاناً • •

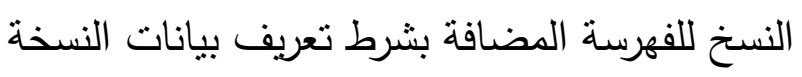
• إمكانية استيراد/تصدير الفهرسة بواسطة ملفات (MARC Row)

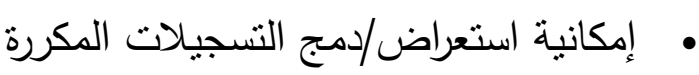




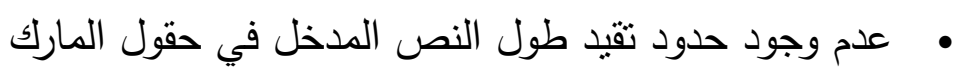

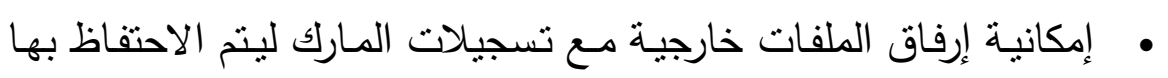

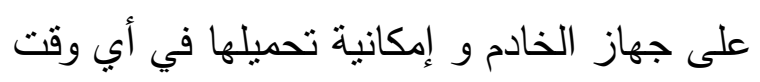

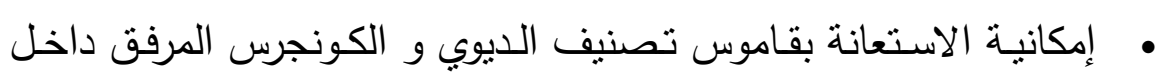
النظام للبحث عن أرقام التصنيف بسهولة لوضعها بالتسجيلات

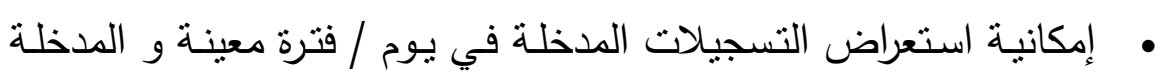
بواسطة شخص محدد و المدخلة في مكتبة بعينها

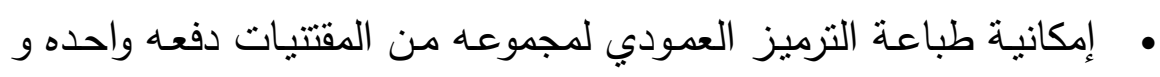

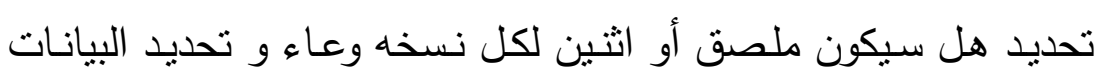
التي ينم طباعتها في كل ملصق على حدى و يمكن استخدام الطابعات العادية و أوراق A4 للطباعة .

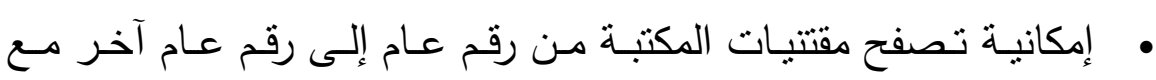

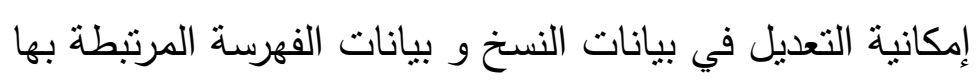

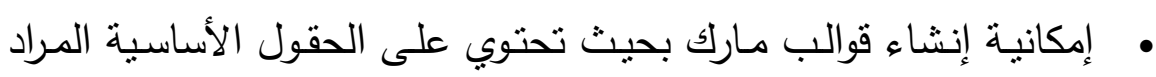

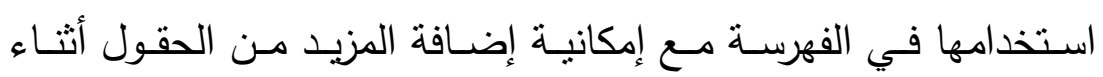
الفهرسة

• دعم نظام الملكية المكانية و الثخصية للنسجيلة في التعامل مع التعديل و الحذف دم: نمان • • إمكانية إنشاء تلقائي لرقم الاستدعاء للنسخة

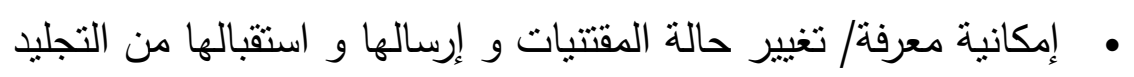

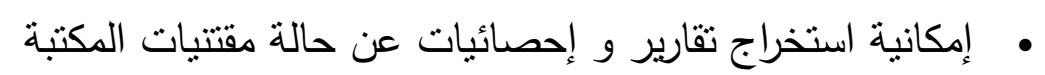

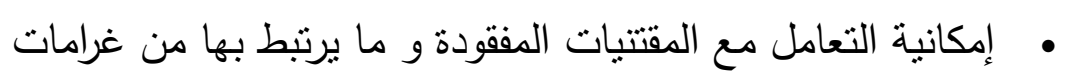




$$
\begin{aligned}
& \text { • • }
\end{aligned}
$$

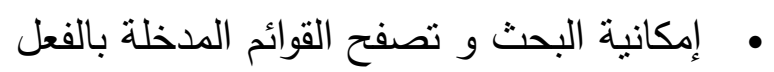

$$
\begin{aligned}
& \text { • • }
\end{aligned}
$$

$$
\text { جـ - ضبط الدوريات }
$$

• إمكانية إنثاء أنماط التتبؤ المختلفة

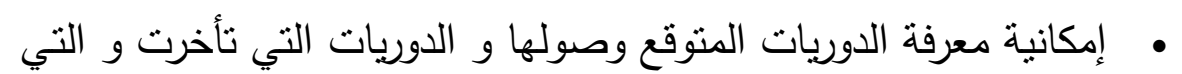

$$
\text { دم - الاستعارة }
$$

• تسجيل وتعديل بيانات المستعيرين أو استيراد البيانات من برنامج شئون

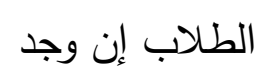

• ضبط صـلاحيات الإعارة و التي تعتمد على الموقع و فئة المستفيد و

$$
\text { نوع الوعاء }
$$

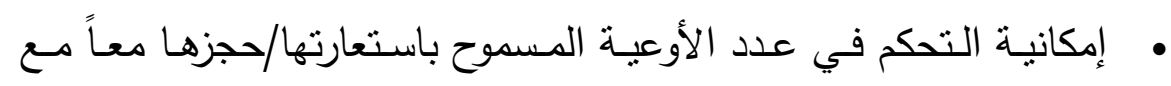
تحديد الفترة التي ينتهي معها الاستعارة/الحجز و عدئ عدد مرات التجديد

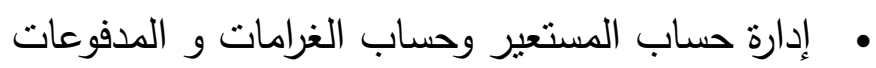

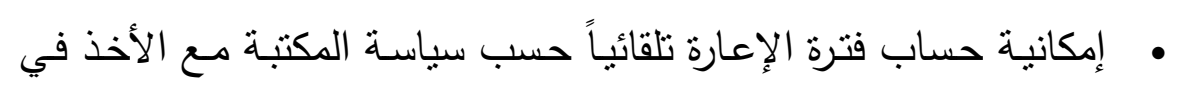

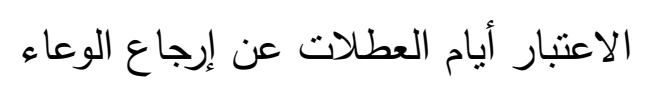

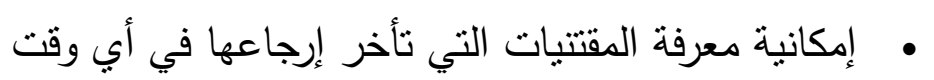

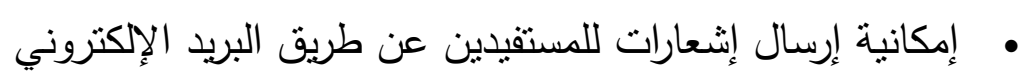

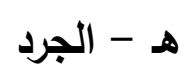


• إككانية جرد العناصر عن طريق ماسح الترميز العمودي

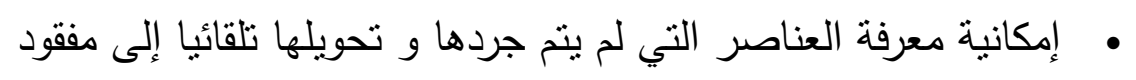

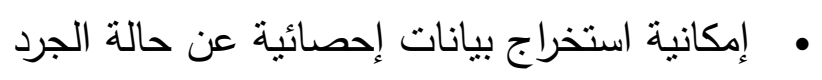
• • إمكانية تصدير نتيجة الجرد إلى صيغة الأكسل

$$
\text { و - البحث }
$$

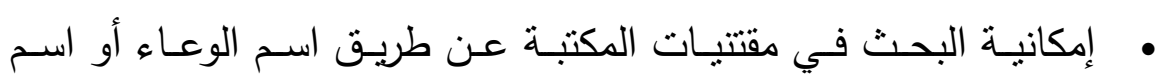

المؤلف أو البحث بالموضوع أو الناشر أو جدول المحتويات ....

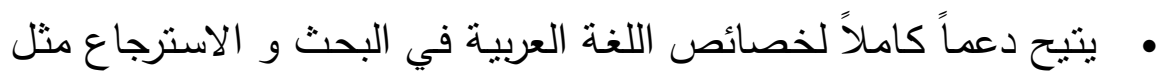

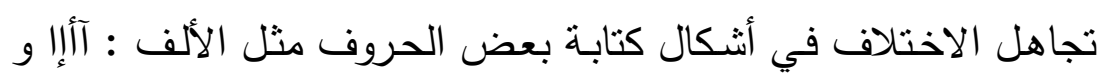

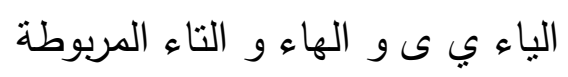

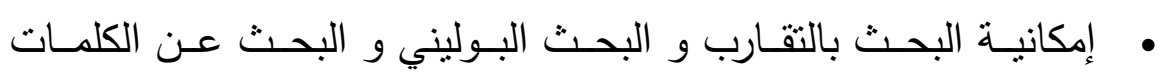
الناقصة

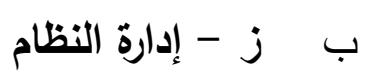

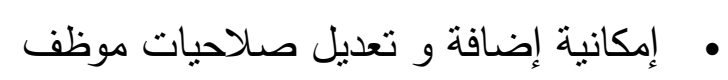

• •

$$
\text { مما يوفر المزيد من الأمان }
$$

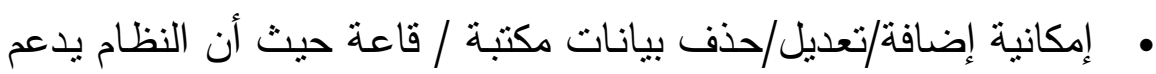

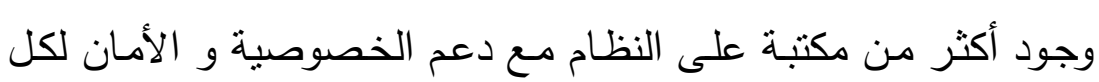

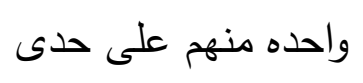

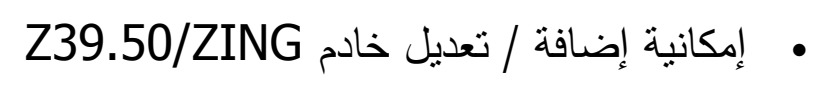


إمكانية إرسال رسائل مع مرفقات إلى موظف أو إلى موظفي مكتبة معينه أو إلى إلى

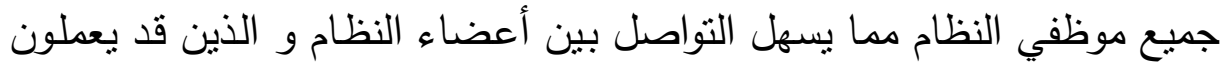
في أماكن منباعدة

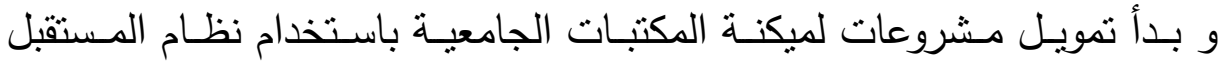

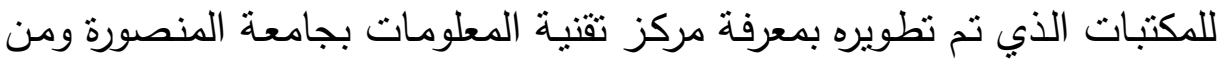

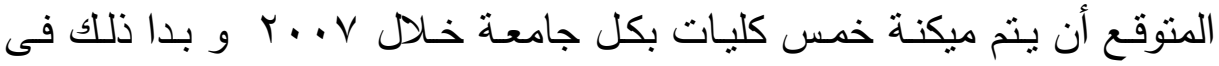

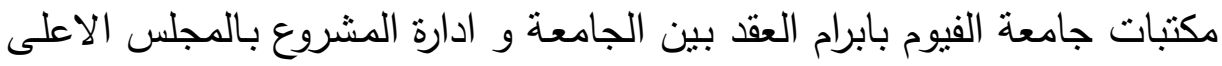

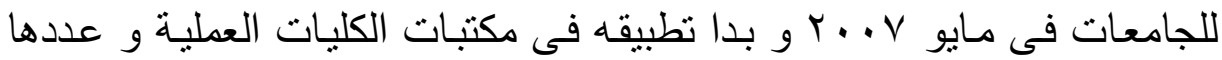

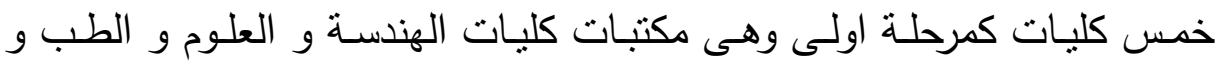

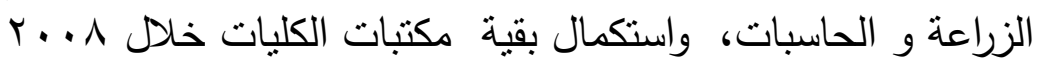
و فيما يلى احصاءات عن مراحل الادخال فى مكتبات جامعة الفئن الفيوم

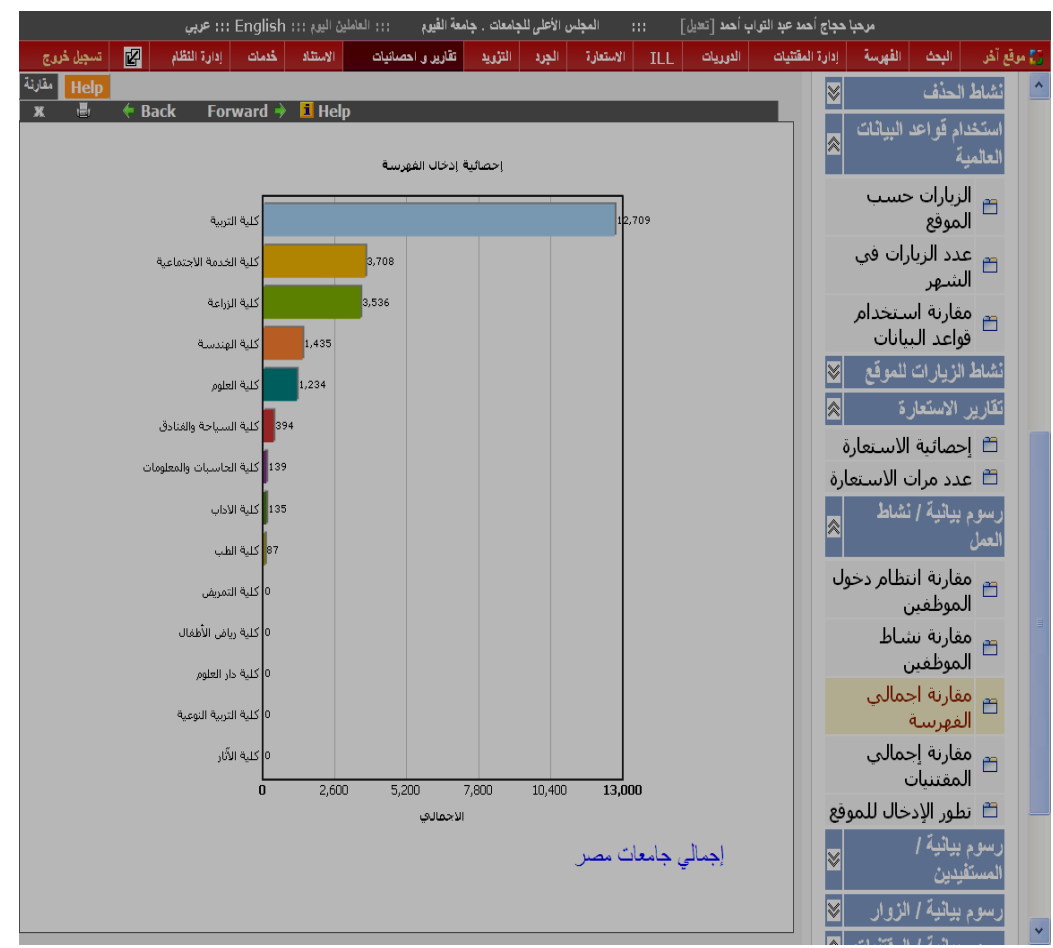

و نلاحظ من الرسم البيانى السابق ان مكتبات جامعة الفيوم قد سبقت مكتبات

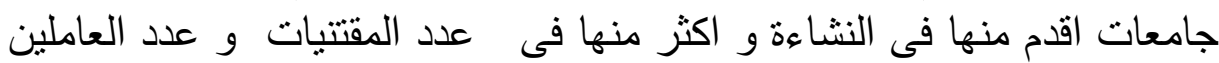

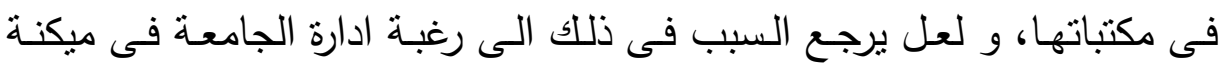

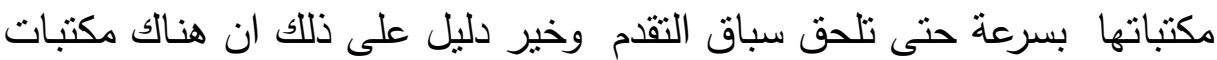




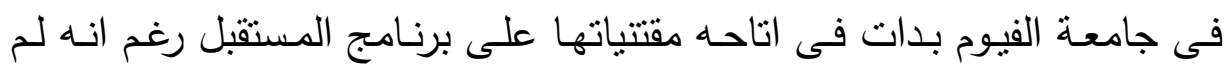

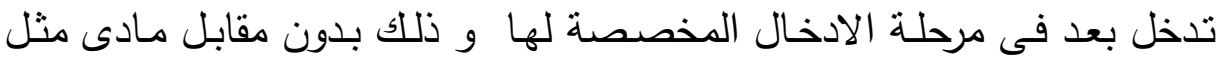

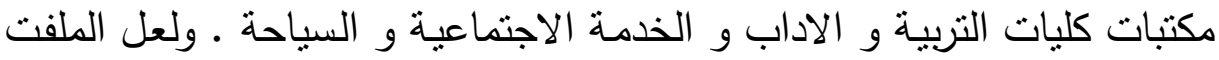

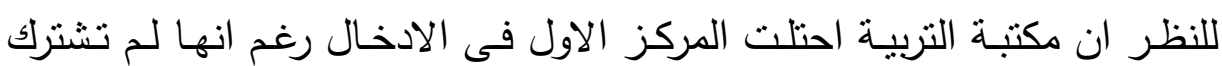

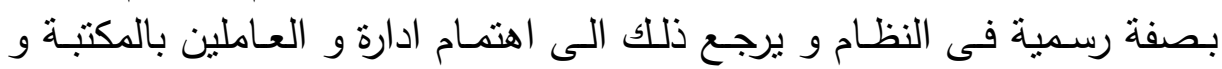

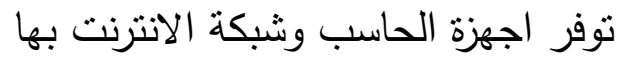

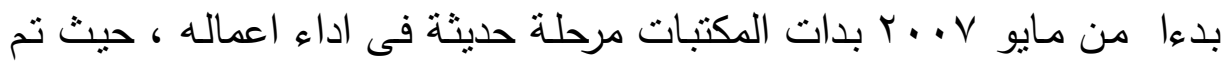

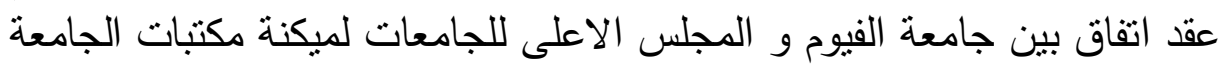

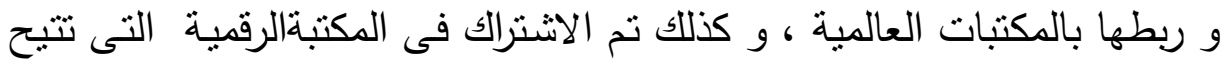

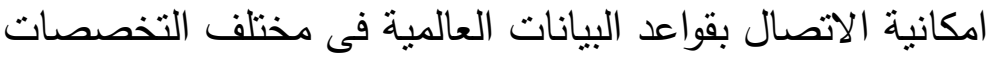

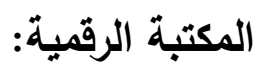

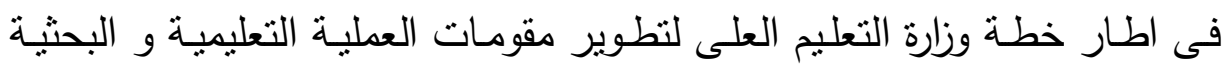

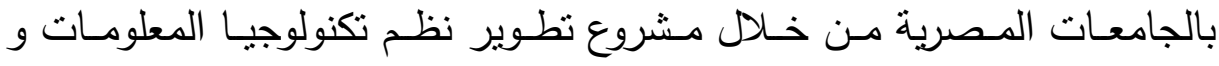

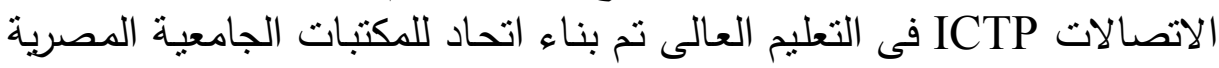

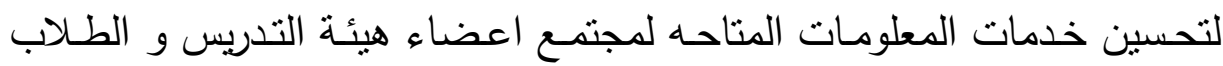

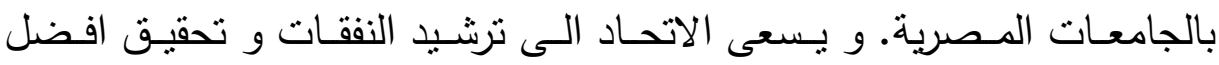

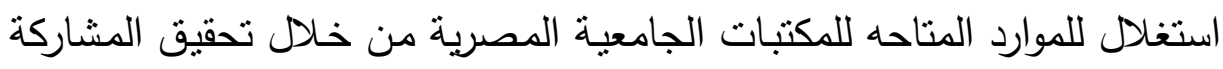

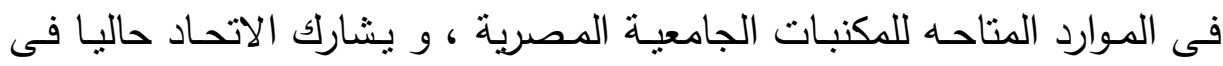

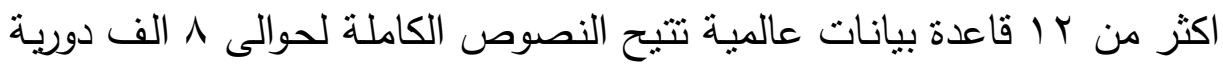

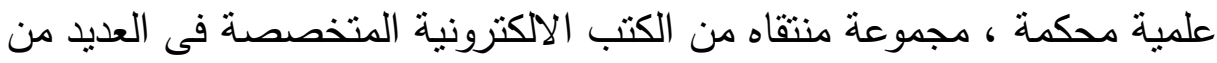

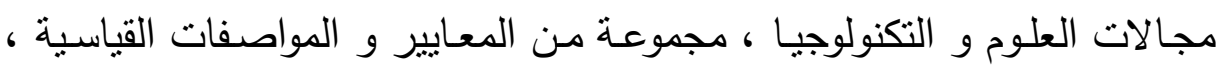

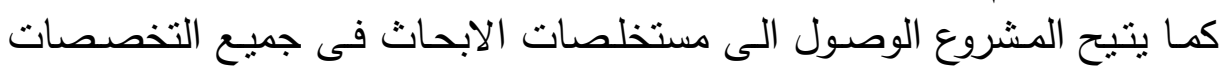

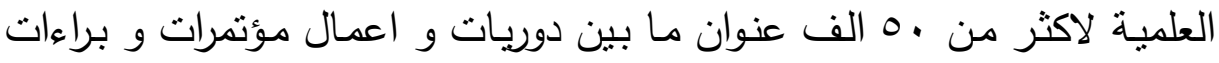

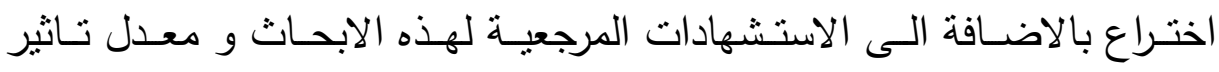

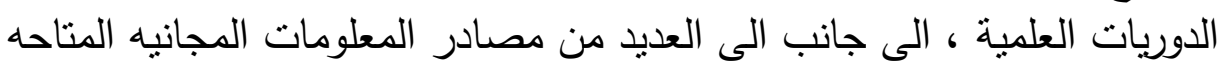

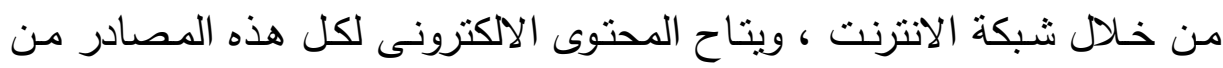

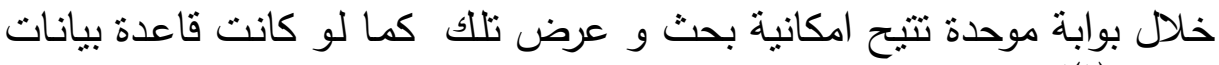

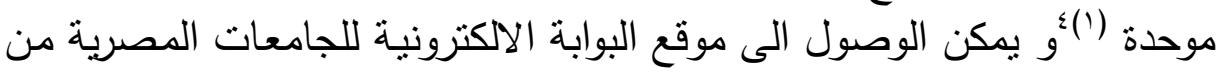
خلال العنوان التالى: 
http://www.eul.edu.eg

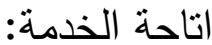
خدمات اتحاد المكتبات الجامعية المصرية متاحه لجميع اعضاء هيئة التدريس و

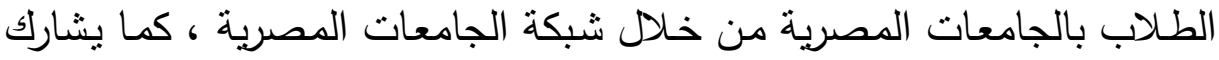

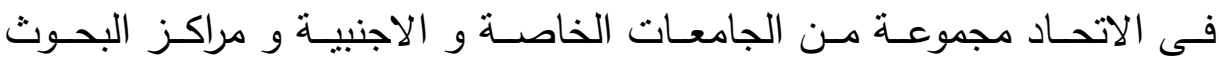

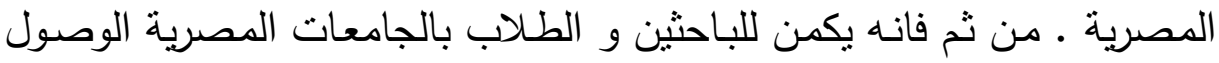

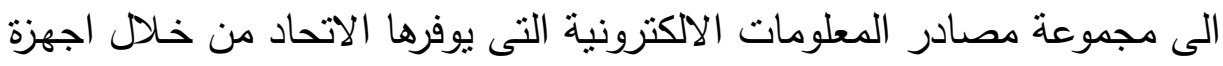

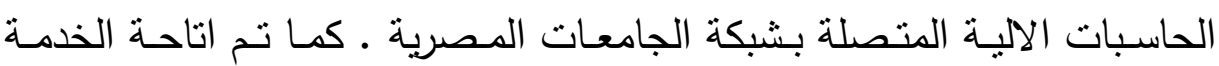

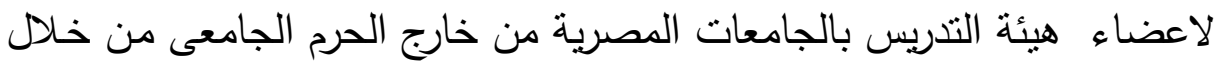

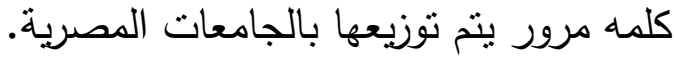

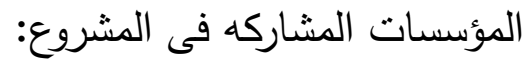

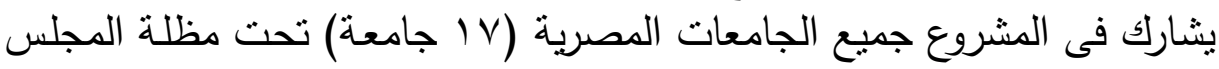

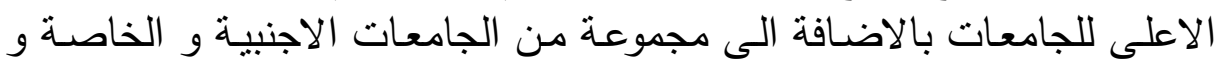

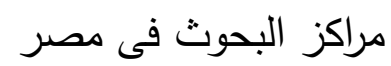

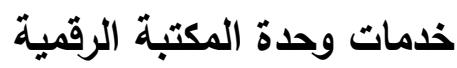
1- البحث فى قواعد البيانات و مصادر الباتة الانترنت

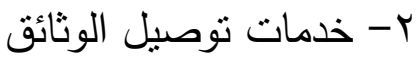
r- ب الاستشارات المكتبية

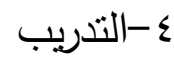

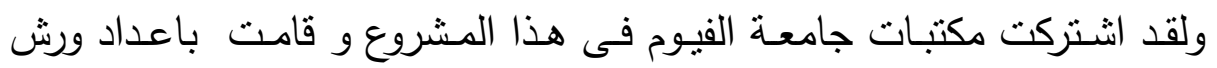

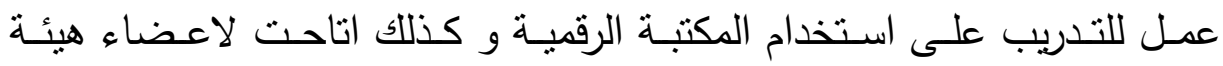

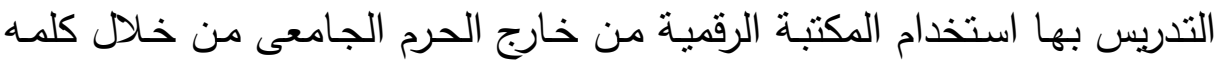

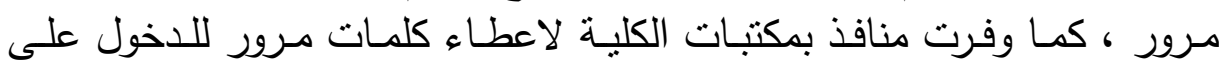

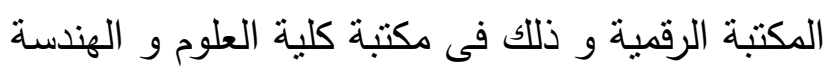

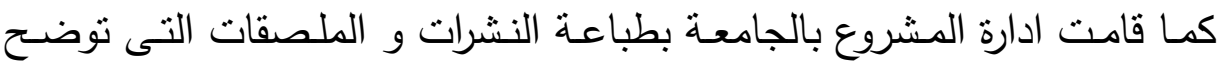

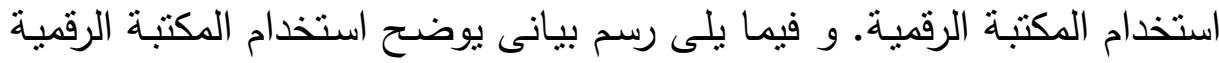

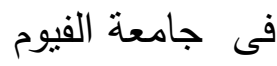

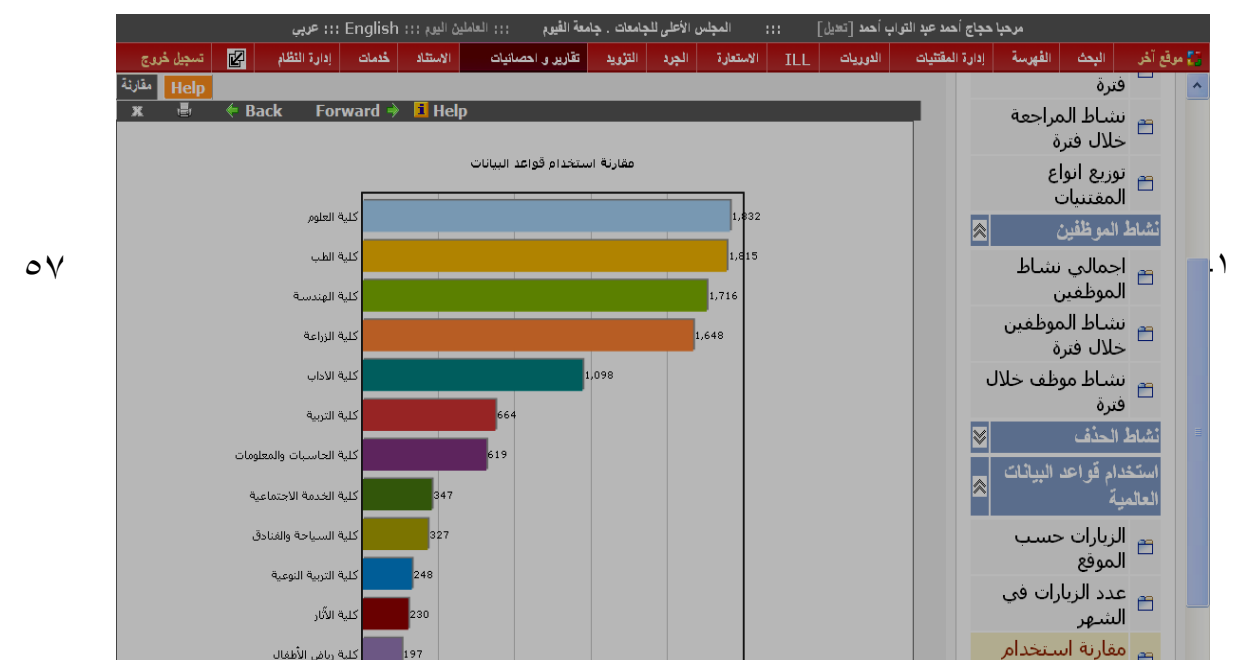




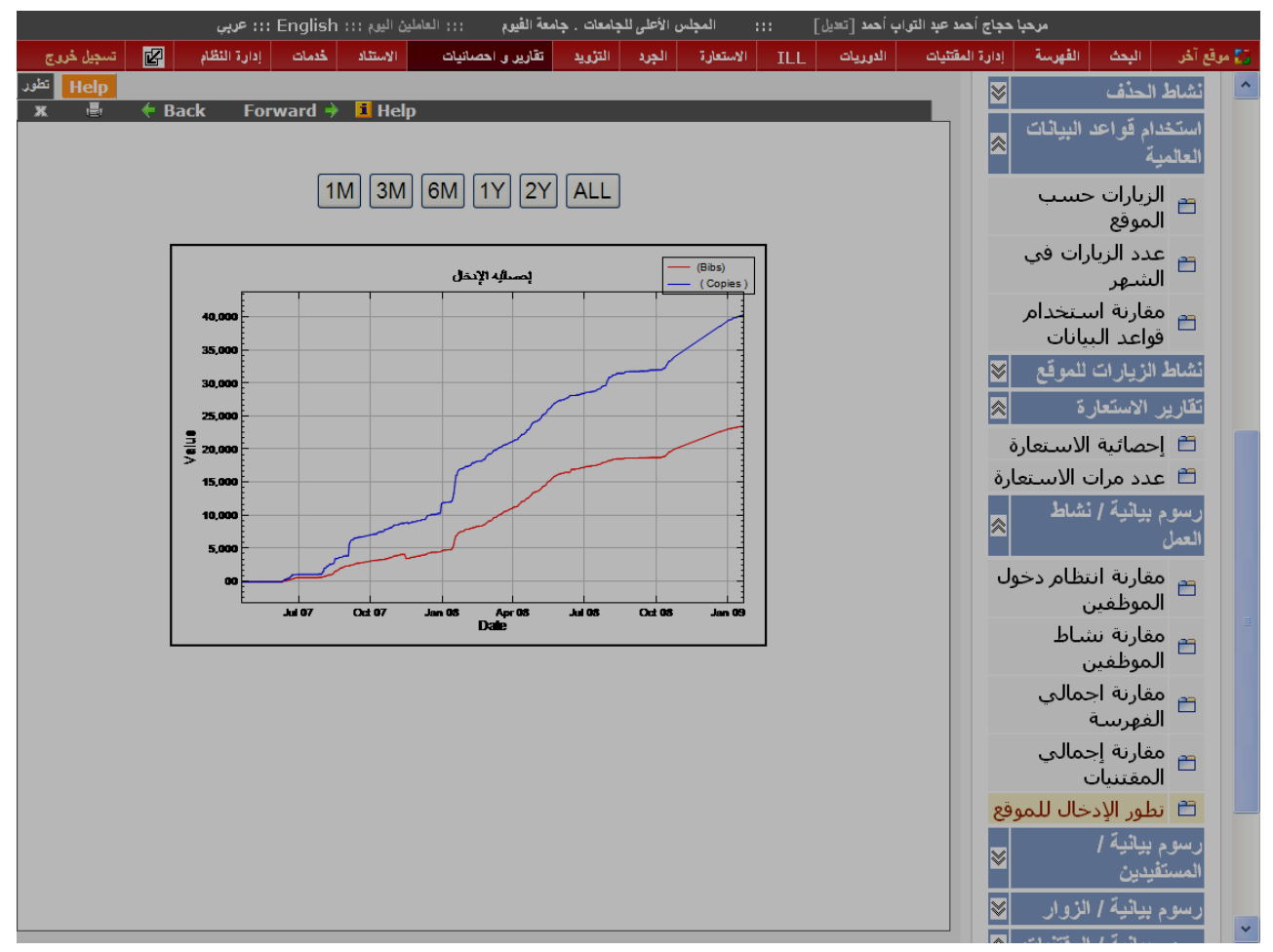


نلاحظ من الرسم السابق ان هناك زيادة فى اعداد مستخدمى المكتبـة الرقميـة

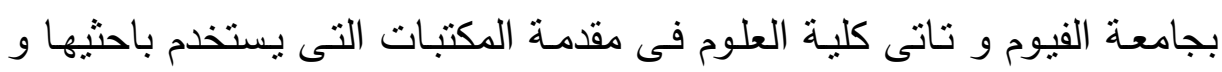

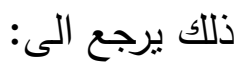

- ان العاملين فى المكتبة من المؤهلين علميا و فنيا على المئ

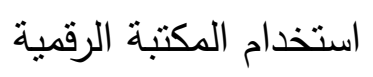

- ان اغلب الموضوعات التى تغطيها المكتبة الرقمية هى ملئه

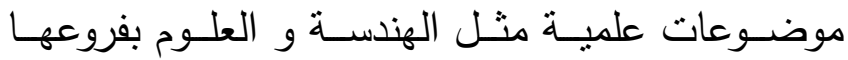

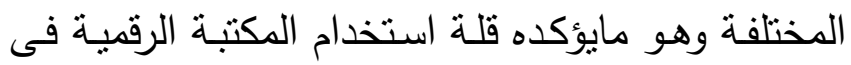

مكتبة دار العلوم وهى احتلت المركز الاخير

الخدمات

تقتصر مكتبات جامعة الفيوم على تقديم خدمتين هما الاطـلاع الداخلى و

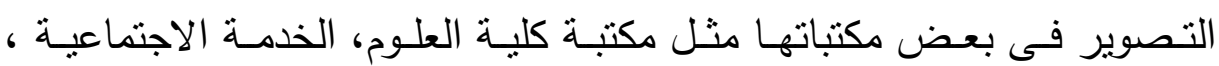
الهندسة ، التربية ، و تقتصر الاستعارة على اعضاء هيئة التدريس فى معظم

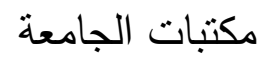

\section{العاملين فى مكتبات جامعة القيوم}

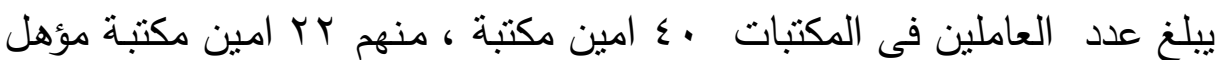

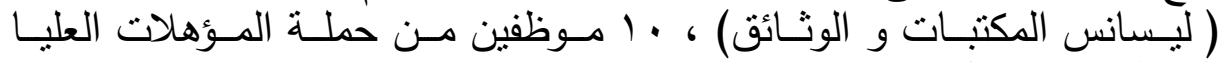

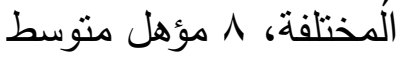


و يوضح الجدول التالى اعداد العاملين فى كل مكتبة و مؤهلاتهم:

\begin{tabular}{|c|c|c|c|c|}
\hline الاجمالى & متوسط مؤهل & مؤهلات عليا & عدد المؤهلين & المكتبة \\
\hline$v$ & r & 1 & $\varepsilon$ & الاجنماعة \\
\hline$\varepsilon$ & $r$ & --- & $r$ & العلوم \\
\hline$\varepsilon$ & --- & $r$ & $r$ & التربية \\
\hline$r$ & --- & ---- & $\mu$ & الهندسة \\
\hline$r$ & 1 & 1 & 1 & زراعة \\
\hline$r$ & 1 & 1 & 1 & الطب \\
\hline$r$ & --- & $r$ & --- & تربية نوعية \\
\hline$r$ & 1 & 1 & 1 & الحاسبات \\
\hline$r$ & --- & --- & 1 & الاداب \\
\hline$r$ & --- & --- & $r$ & السياحة \\
\hline r & 1 & --- & 1 & الاثار \\
\hline$r$ & --- & 1 & 1 & دار العلوم \\
\hline 1 & --- & --- & 1 & رياض الاطفال \\
\hline$\varepsilon$. & $\Lambda$ & 1. & rr & الاجمالى \\
\hline
\end{tabular}

و قد كان لمكتبة الخدمة الاجتماعية النصيب الاكبر فى عدد العاملين المؤهلين

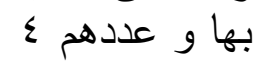
تلايها مكتبة كلية الهندسة بعدد ب امين مكتبة مؤهل، بينما اقلها فى عدد العاملين المؤهلين كانت كلية رياض الاطفة بطال

ولقد كان حرص الجامعة على وجود مكتبى مؤهل على الاقل فى كل مكتبة اثره

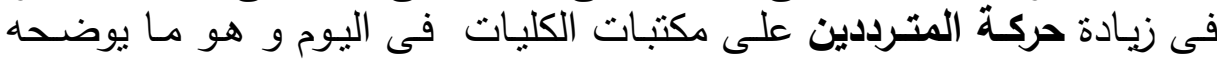

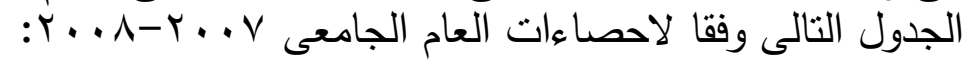
7. 


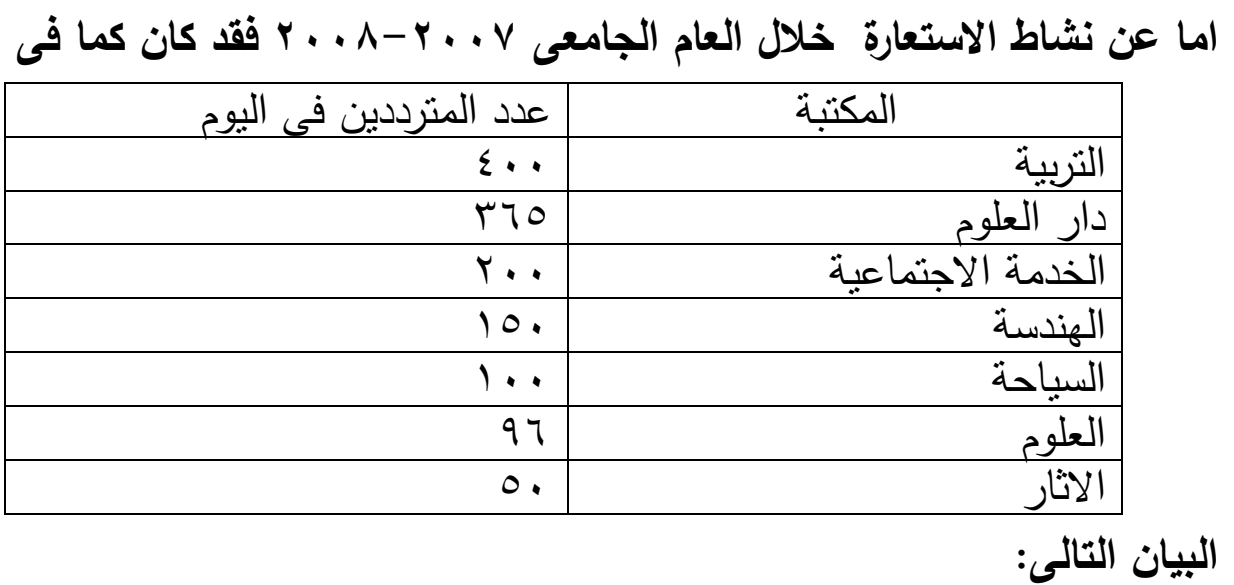

\begin{tabular}{|c|c|c|}
\hline أعضاء هيئة التلريس & لطلاب المستعرون خلال العام & المكتبة \\
\hline $1 \ldots$ & $0 \ldots$ & الزئدة \\
\hline 11 & $r r$. & الطب \\
\hline$r \cdot$. & -- & الزراعة \\
\hline iro & -- & 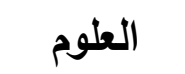 \\
\hline $1 \cdot 1$ & -- & التربية \\
\hline VI & 11 & 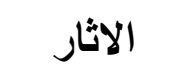 \\
\hline$\varepsilon 9$ & -- & السياحة \\
\hline$\varepsilon 0$ & $\wedge \wedge$ & الخدمة الخة \\
\hline & & الاجتماعية \\
\hline 10 & -- & دار العلوم \\
\hline
\end{tabular}




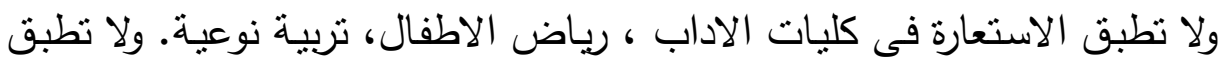

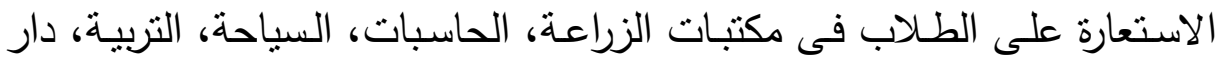

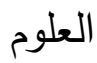

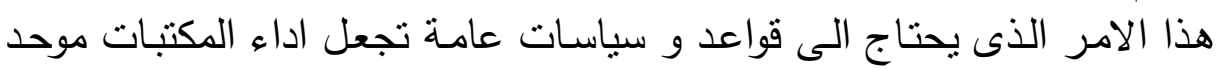

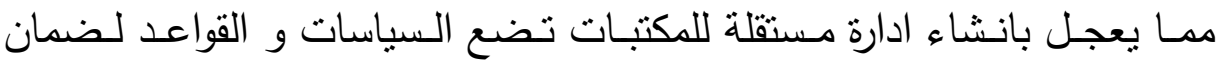
التوحيد فى الاداء بين المكتبات فى الجامعة الواحدة

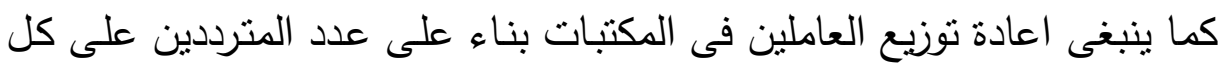

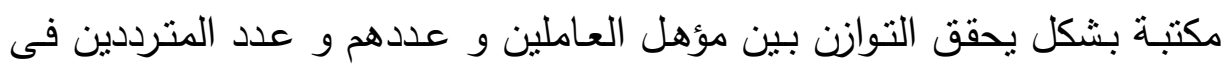
اليوم الواحد و الانشطة و الخدمات التى تؤديها المكتبة واذا وجد عجز فى تحقيق

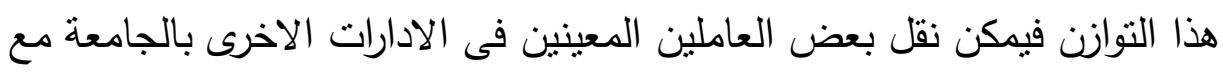
تدريبهم الندريب المناسب الذى يجعهم قادرون على اداء الاعمال

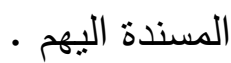

الصعويات التى تواجه مكتبات جامعة الفيوم و كيفيه التظلب عليها: 
تواجه اجامعة الفيوم بعض الصعوبات و المشاكل التى قد تعوق تطوير اداء

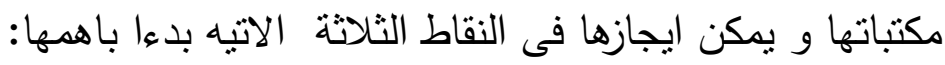

$$
\text { r- r- مشاكل ادارية }
$$

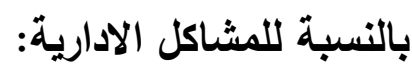

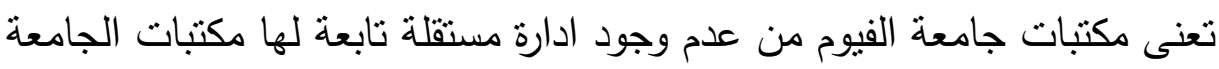

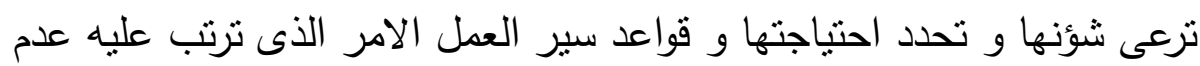

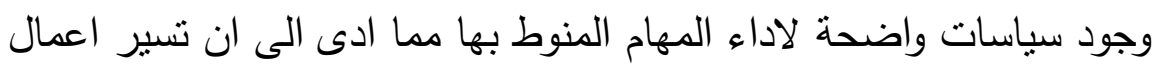

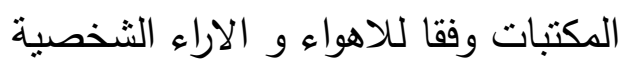

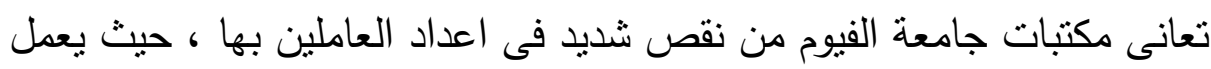

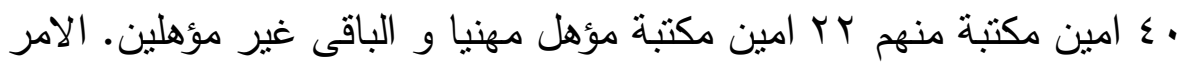

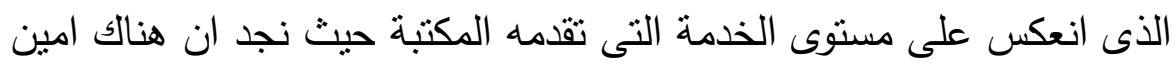

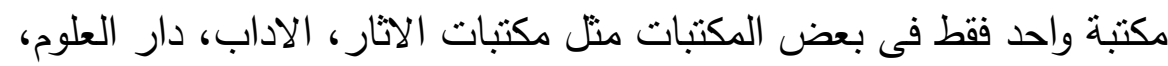

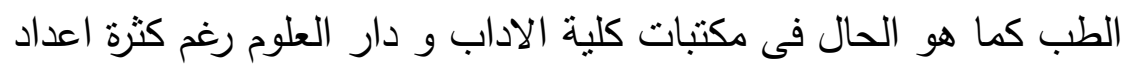

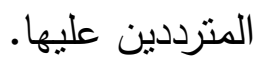

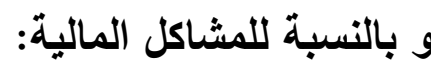

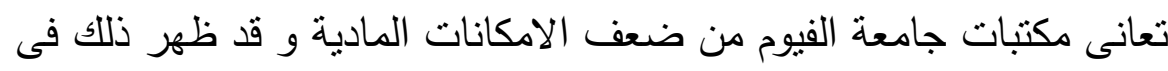

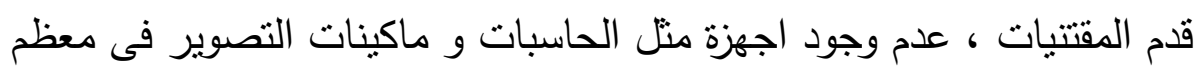

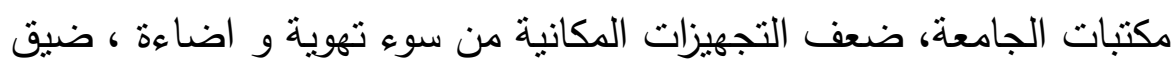

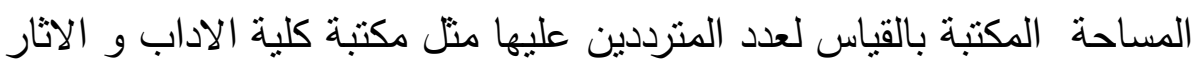
و السياحة حرمان امناء المكتبات من الحصول على اى حوافز مالية مساواه بباقى العاملين

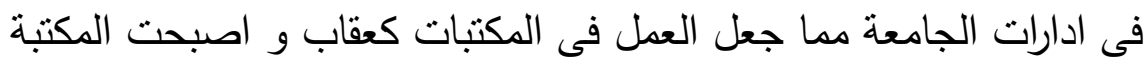
مكان للطرد و ليس للجذب في العمل بها

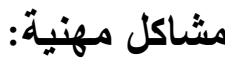


انعدام الدورات التنريبية للعاملين فى المكتبات اثر سلبا على مستوى اداء العاملين فى المكتبات ، و و تاخرهم عن ملاحقة التطور فى المجال.

و لذلك فاننى اقترح لحل المشكلات السابقة فى النقاط التالية:

1- انثاء ادارة مسنقلة للمكتبات الجامعية و ان تكون تابعة مبانشرة الى نائب رئيس الجامعة للدراسات العليا

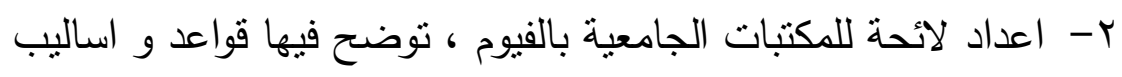

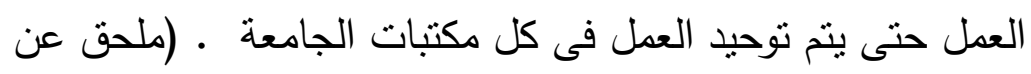
تصور مقترح للائحة مكتبات جامعة الفيوم )

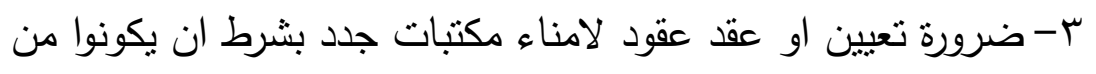

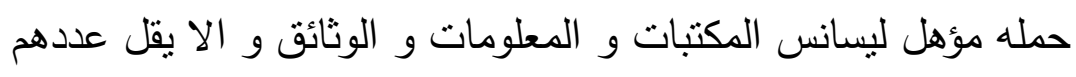
عن 10 موظف. ينت توزيعهم حسب احتياج كل مكتبة.

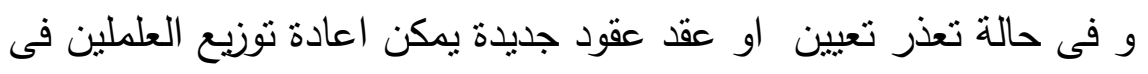

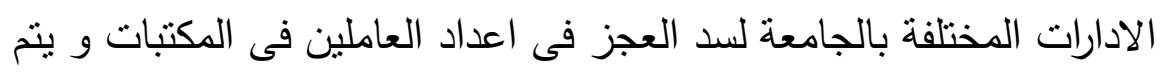
تدريبهم على اساليب العمل فى المكتبات.

ع - ضرورة صرف حوافز مالية للعاملين فى مكتبات الجامعة وذللك من

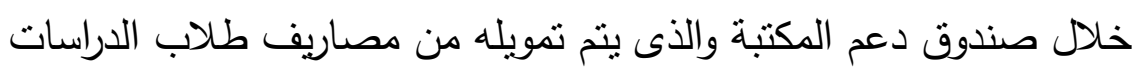

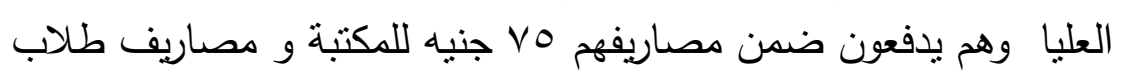
المرحلة الجامعية الاولى و الذين يدفعون خمس جنيهات الئهات للمكتبة فيتم

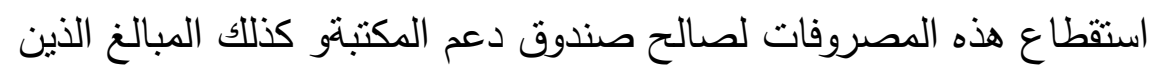

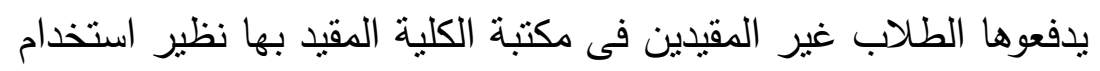
المكتبة وفقا لنص اللائحة المقترح 
0- نزويد المكتبات بوسائل التهوية المناسبة و الاضاءة و نوصيل نقاط

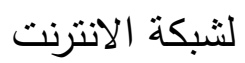

7-اعداد دورات مهنية للعاملين فى المكتبات كما سيرد لاحقا و الحرص

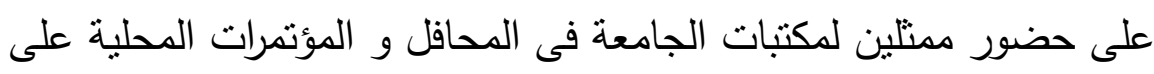

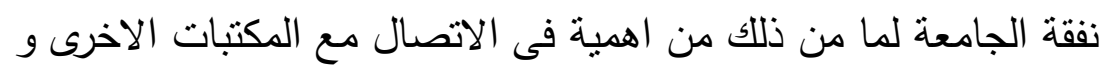
الحصول على المعلومات الحديثة.

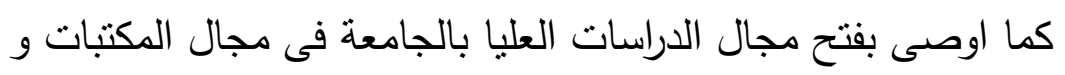

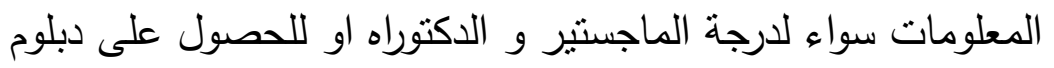

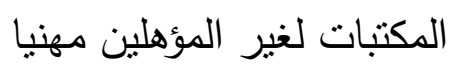

V- ضرورة عدم نقل اى موظف فى المكتبة الى اى ادارة اخرى خاصة الذين اجتازوا دورات متخصصة في المكتبات

^- وضع مكتبات جامعة الفيوم على شبكة الانترنت ضمن موقع الجامعة و ذلك للتعريف بمكتبات الجامعة

9 - عمل جولات ارشادية لطلاب الفرقة الاولى بجميع الكليات فى بداية العام الجامعى للتعريف بالمكتبة وطريقة استخدامها

• 1- زيادة ساعات العمل بالمكتبات حتى الثامنة مساء مع مراعاه الحافز المادى للعاملين فى المكتبات

11 - انشاء مكتبة مركزية للجامعة و ضرورة اقتنائها لمختلف انواع اوعية

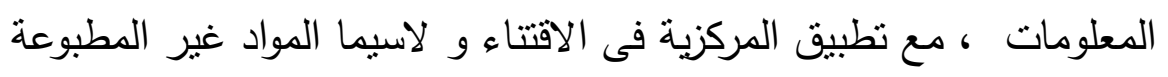

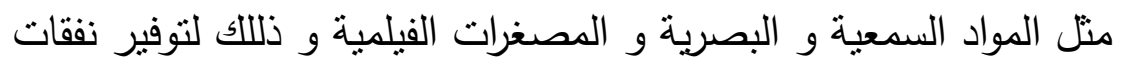
شراء هذه المواد و اجهزة تشغيلها 


$$
\begin{aligned}
& \text { r ا - اعداد برنامج جيد للاعلام عن مكتبات الجامعة و التعريف بها و نشر } \\
& \text { هذا البرنامج بين مختلف المستقيدين } \\
& \text { ب ا -تفعيل دور لجان المكتبات بالكليات }
\end{aligned}
$$

ـ ا -تطبيق مبدا الثواب و العقاب على العاملي فى المكتبات تشجيعا

للمجتهد و محاولة الاخذ بيد المقصر للافضل و متابعة تقييم اداء العاملين

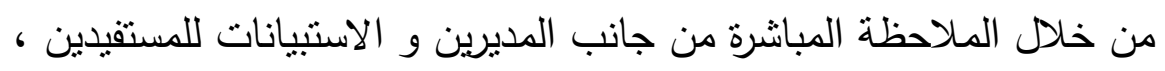

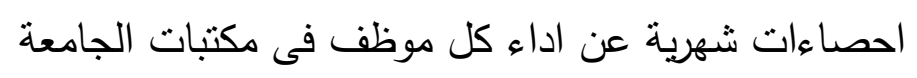

البرنامج التدريبي المقترح

$$
\text { تبدا هذه الدورات على مراحل و هى: }
$$

المرحلة الاولى: مخصصة لمديرى المكتبات و تشمل دورات دورات فى الموضوعات الاتيه:

عدد الساعات

$$
\text { الموضوع }
$$

المقترحة الموصوع

ادارة المكتبات و مراكز المعلومات ---------------_ ع نظرى

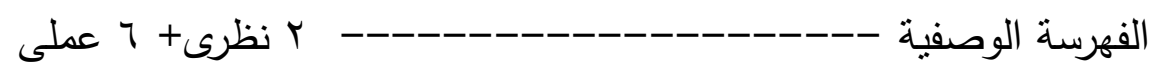

الفهرسة الوصفية المنقدمة ( فهرسة دوريات،مصغرات،ملفات الية)- بنظرى+1 عملى نظيل

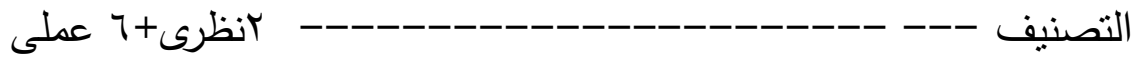

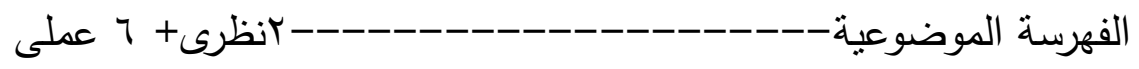

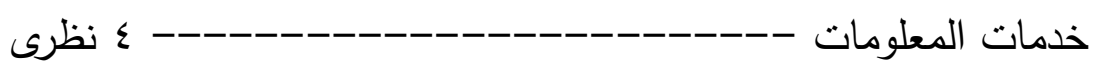
استخدام الحاسب فى المكتبات -------------- ع نظرى +--_ ع عملى

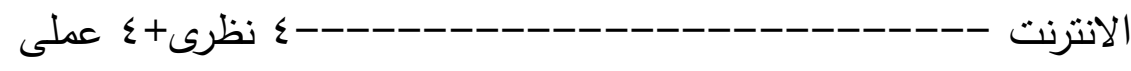
74 


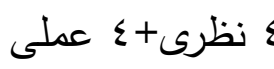

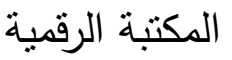

المرحلة الثانية: لامناء المكتبات من حملة ليسانس المكتبات و الوثائق ولا

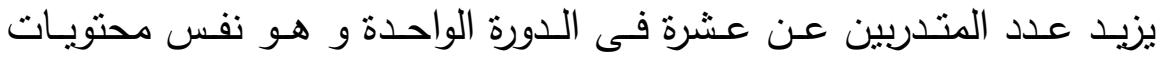
التدريب السابق باستثاء موضوع عن الادارة

المرحلة الثالثة: لحملة المؤهلات العليا المختلفة غير المكتبات و المعلومات

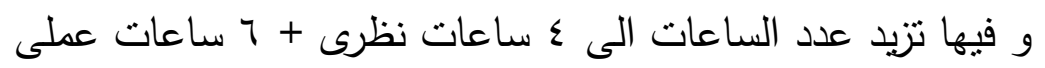

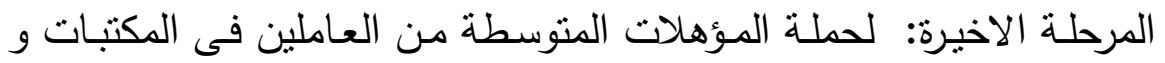

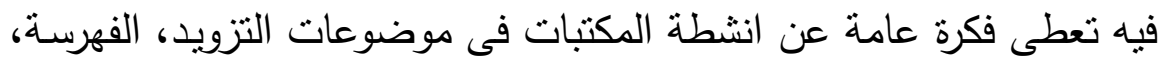

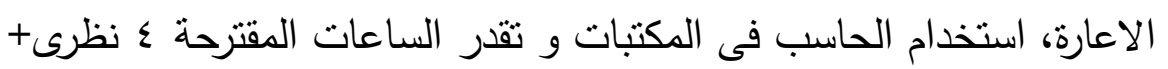
r e r الأنى

ويتطلب تتفيذ هذا البرنامج قاعة مجهزة للتندريب تكفى لعشرة افراد و مزودة

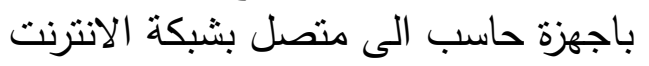
اللائحة المقترحة لمكتبات جامعة الفيوم

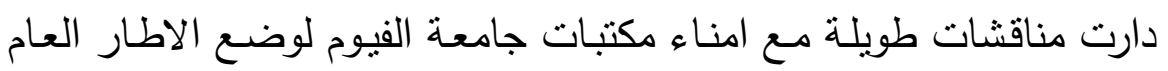

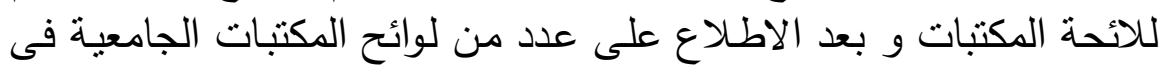

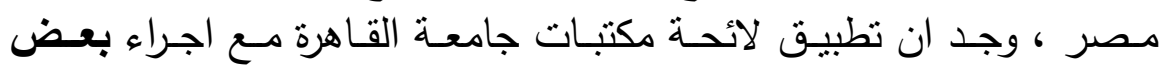

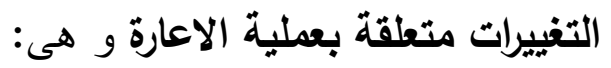

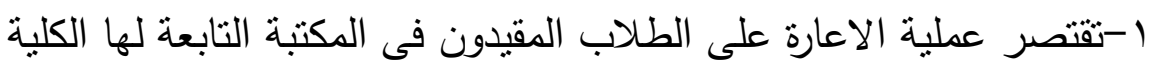
وكذلك اعضاء هيئة التدريس و العاملين الطين

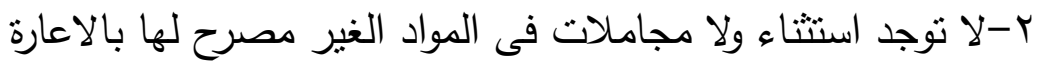

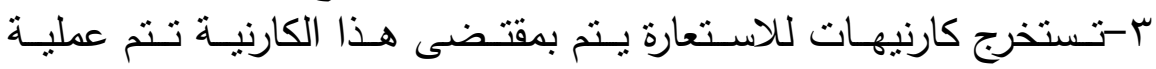

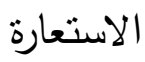
ع-يسمح الاستعارة لطـلاب المرحلة الجامعيـة الاولى و الطـلاب المنتسبين

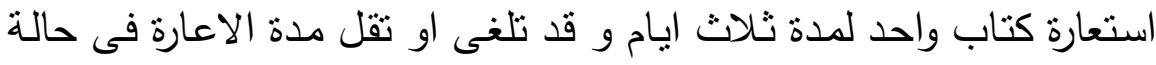

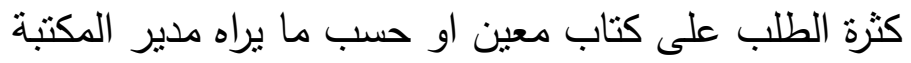

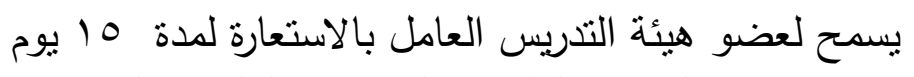

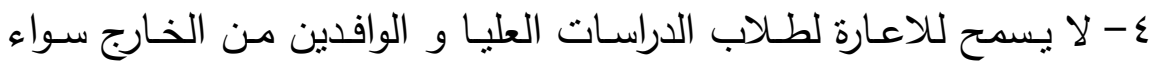

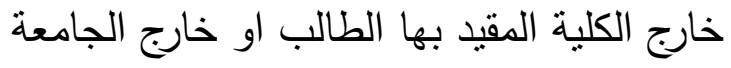




\section{بالنسبة للغرامات المفروضة عند تاخير عملية رد الكتاب هي:}

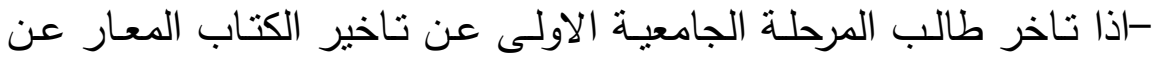

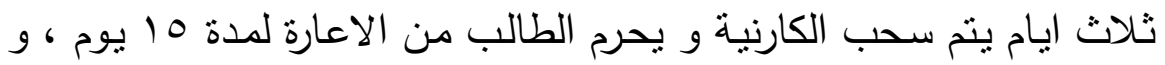

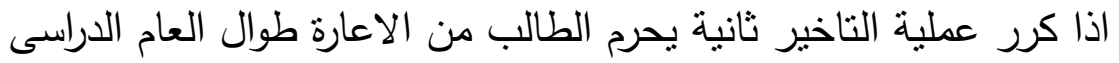
-بالنسبة لعضو هيئة التذريس بعد 10 يوم و لم يردية يجرد او يجدد عملية الاعارة

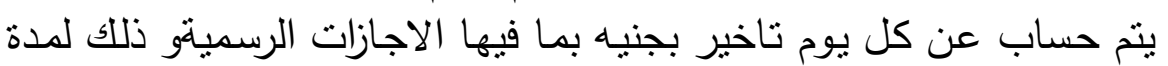

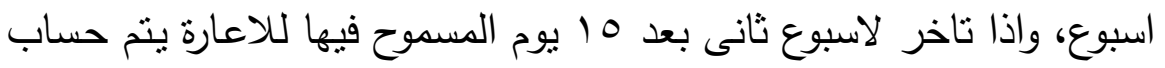

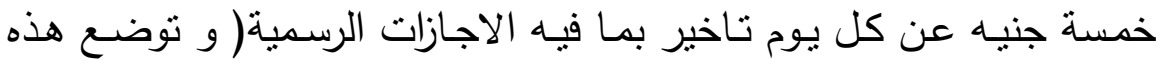
الماليات فى صندوق دعم المكنبة)

فى حالة رغبـة طالب او عضو هيئة تدريس فى مكتبـة غير تابعـة للكليـة

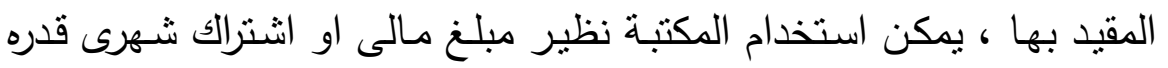

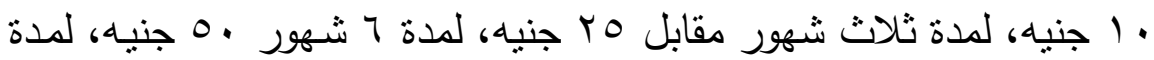

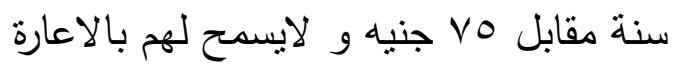

يسمح الاطلاع على الرسائل العلمية و شرائط (مواد سمعية وبصرية) بعد

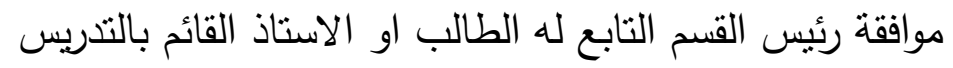

يسمح تصوير الكتب و الرسائل فى حدود · 1 \% من حجم الوعاء المراد

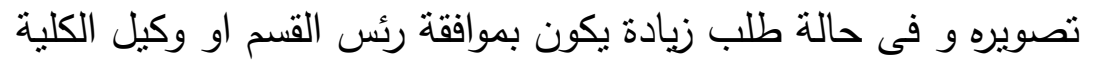

الروئية المستقبلية:

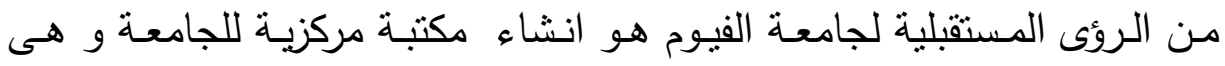

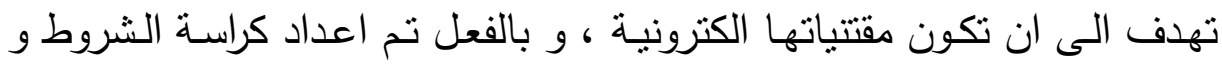

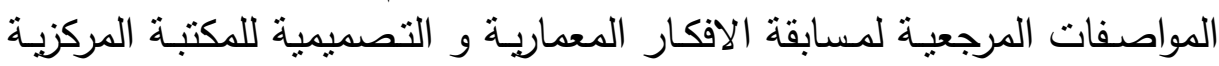

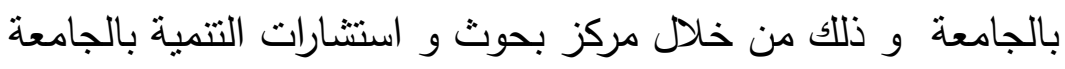

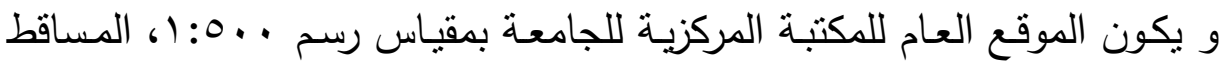

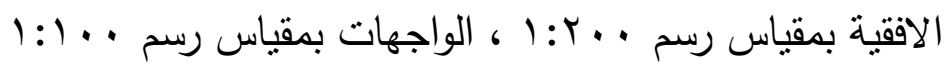




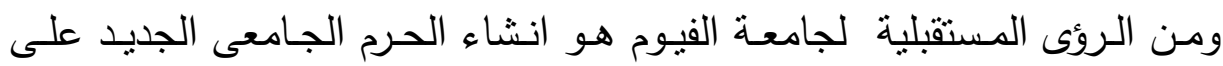

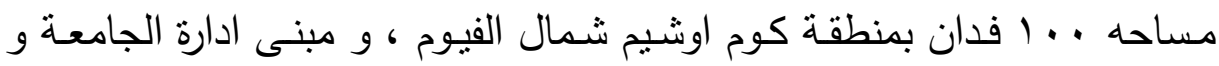

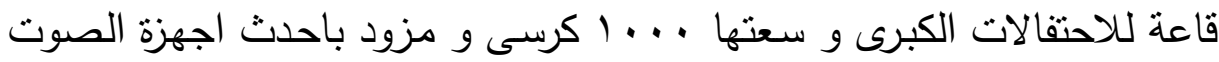

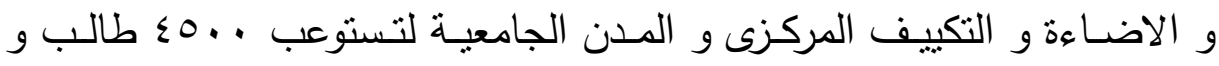

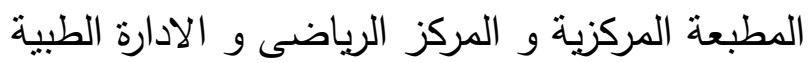

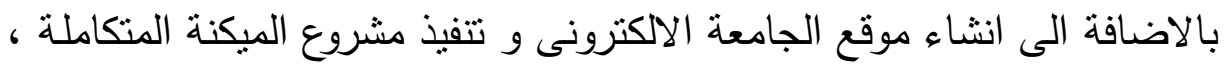

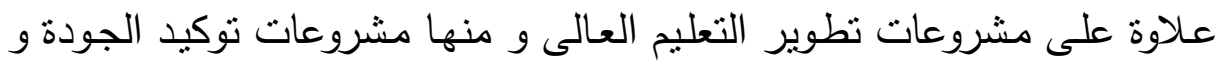

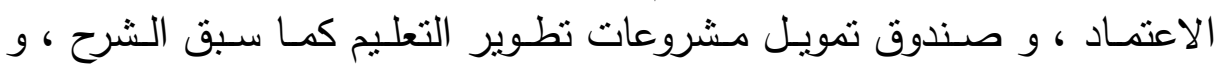

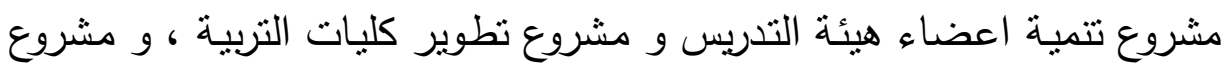

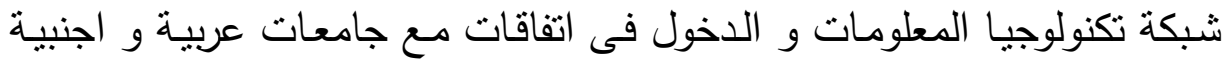
لتنجيع التبادل العلمى للطلاب و اعضاء لاء هيئة التنريس

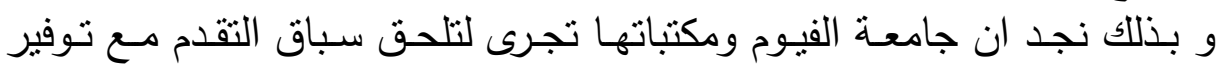
الامكانات المادية و البشرية اللازمة للوصول الى قطار التقام رغم صغر سنها لتها

$$
\text { قائمة المراجع }
$$

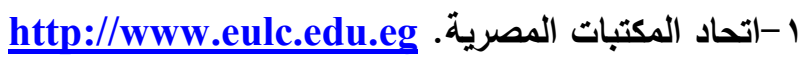

r- احمد بدرومحد فتحى عبد الهادى. المكتبات الجامعية :دراسات فى المكتبات الاكاديمية

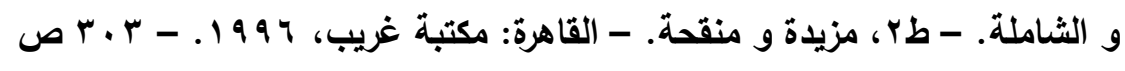

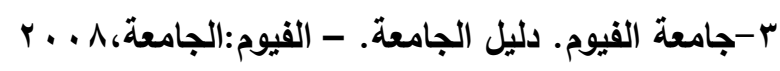

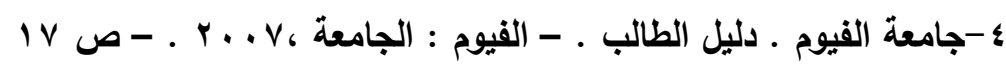
ه-جامعة القاهزة ـ اللائحة الداخلية لمكتبات جامعة القاهرة

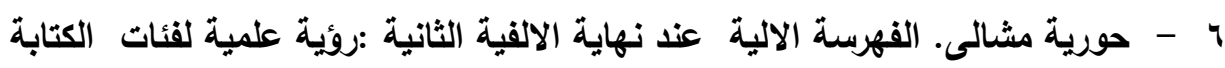

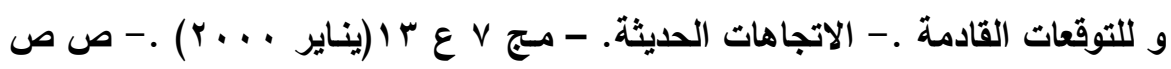

$$
r \leq \cdot-r \cdot r
$$

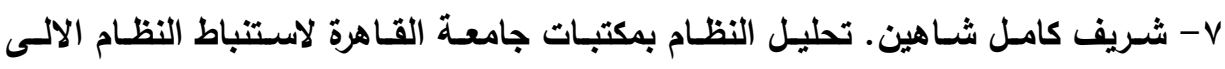

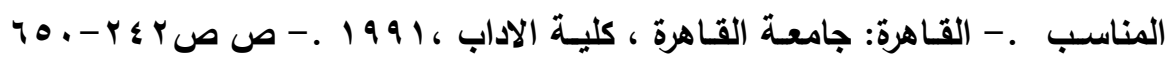
اطروحة دكتوراه

^- محمد فتحى عبد الهادى. نحو تطوير جامعة القاهرة .- دراسات عربية فى المكتبات و 


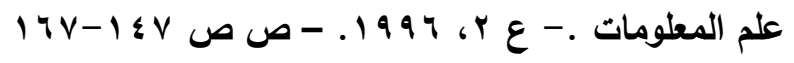

http://www.heep.edu.eg - وزارة التعليم العالى . 